\title{
Overview of the 2010 Carbonaceous Aerosols and Radiative Effects Study (CARES)
}
R. A. Zaveri ${ }^{1}$, W. J. Shaw ${ }^{1}$, D. J. Cziczo ${ }^{2}$, B. Schmid ${ }^{1}$, R. A. Ferrare ${ }^{3}$, M. L. Alexander ${ }^{4}$, M. Alexandrov ${ }^{5}$, R. J. Alvarez ${ }^{6}$, W. P. Arnott ${ }^{7}$, D. B. Atkinson ${ }^{8}$, S. Baidar ${ }^{9}$, R. M. Banta ${ }^{6}$, J. C. Barnard ${ }^{1}$, J. Beranek ${ }^{1}$, L. K. Berg ${ }^{1}$, F. Brechtel ${ }^{10}$, W. A. Brewer ${ }^{6}$, J. F. Cahill ${ }^{11}$, B. Cairns ${ }^{12}$, C. D. Cappa ${ }^{13}$, D. Chand ${ }^{1}$, S. China ${ }^{14}$, J. M. Comstock ${ }^{1}$, M. K. Dubey ${ }^{15}$, R. C. Easter ${ }^{1}$, M. H. Erickson ${ }^{16}$, J. D. Fast $^{1}$, C. Floerchinger $^{17}$, B. A. Flowers ${ }^{15}$, E. Fortner ${ }^{18}$, J. S. Gaffney ${ }^{19}$, M. K. Gilles ${ }^{20}$, K. Gorkowski ${ }^{14}$, W. I. Gustafson ${ }^{1}$, M. Gyawali ${ }^{7}$, J. Hair ${ }^{3}$, R. M. Hardesty ${ }^{6}$, J. W. Harworth ${ }^{8}$, S. Herndon ${ }^{18}$, N. Hiranuma ${ }^{1}$, C. Hostetler ${ }^{3}$, J. M. Hubbe ${ }^{1}$, J. T. Jayne ${ }^{18}$, H. Jeong ${ }^{21}$, B. T. Jobson ${ }^{16}$, E. I. Kassianov ${ }^{1}$, L. I. Kleinman ${ }^{22}$, C. Kluzek ${ }^{1}$, B. Knighton $^{17}$, K. R. Kolesar ${ }^{13}$, C. Kuang ${ }^{22}$, A. Kubátová21 , A. O. Langford ${ }^{6}$, A. Laskin $^{4}$, N. Laulainen ${ }^{1}$, R. D. Marchbanks ${ }^{6}$, C. Mazzoleni ${ }^{14}$, F. Mei ${ }^{22}$, R. C. Moffet ${ }^{23}$, D. Nelson ${ }^{1}$, M. D. Obland ${ }^{3}$, H. Oetjen ${ }^{9}$, T. B. Onasch ${ }^{18}$, I. Ortega ${ }^{9}$, M. Ottaviani ${ }^{24}$, M. Pekour ${ }^{1}$, K. A. Prather ${ }^{11}$, J. G. Radney ${ }^{8}$, R. R. Rogers ${ }^{3}$, S. P. Sandberg ${ }^{6}$, A. Sedlacek ${ }^{22}$, C. J. Senff ${ }^{6}$, G. Senum ${ }^{22}$, A. Setyan ${ }^{25}$, J. E. Shilling ${ }^{1}$, M. Shrivastava ${ }^{1}$, C. Song ${ }^{1}$, S. R. Springston ${ }^{22}$, R. Subramanian ${ }^{26}$, K. Suski ${ }^{11}$, J. Tomlinson ${ }^{1}$, R. Volkamer ${ }^{9}$, H. W. Wallace ${ }^{16}$, J. Wang ${ }^{22}$, A. M. Weickmann ${ }^{6}$, D. R. Worsnop ${ }^{18}$, X.-Y. Yu ${ }^{1}$, A. Zelenyuk ${ }^{27}$, and Q. Zhang ${ }^{25}$

${ }^{1}$ Atmospheric Sciences \& Global Change Division, Pacific Northwest National Laboratory, Richland, WA, USA

${ }^{2}$ Massachusetts Institute of Technology, Cambridge, MA, USA

${ }^{3}$ NASA Langley Research Center, Hampton, VA, USA

${ }^{4}$ Environmental Molecular Sciences Laboratory, Pacific Northwest National Laboratory, Richland, WA, USA

${ }^{5}$ Department of Applied Physics and Applied Mathematics, Columbia University, New York, NY, USA

${ }^{6}$ Chemical Sciences Division, NOAA Earth System Research Laboratory, Boulder, CO, USA

${ }^{7}$ University of Nevada, Reno, NV, USA

${ }^{8}$ Portland State University, Portland, OR, USA

${ }^{9}$ Department of Chemistry and Biochemistry, University of Colorado at Boulder, CO, USA

${ }^{10}$ Brechtel Manufacturing, Inc, Hayward, CA, USA

${ }^{11}$ University of California, San Diego, CA, USA

${ }^{12}$ NASA Goddard Institute for Space Studies, New York, NY, USA

${ }^{13}$ Department of Civil and Environmental Engineering, University of California, Davis, CA, USA

${ }^{14}$ Atmospheric Science Program, Michigan Technological University, Houghton, MI, USA

${ }^{15}$ Los Alamos National Laboratory, Los Alamos, NM, USA

${ }^{16}$ Washington State University, Pullman, WA, USA

${ }^{17}$ Montana State University, Bozeman, MT, USA

${ }^{18}$ Aerodyne Research, Inc., Billerica, MA, USA

${ }^{19}$ University of Arkansas, Little Rock, AR, USA

${ }^{20}$ Lawrence Berkeley National Laboratory, Berkeley, CA, USA

${ }^{21}$ University of North Dakota, ND, USA

${ }^{22}$ Brookhaven National Laboratory, Upton, NY, USA

${ }^{23}$ University of the Pacific, Stockton, CA, USA

${ }^{24}$ NASA Postdoctoral Program Fellow, NASA Goddard Institute for Space Studies, New York, NY, USA

${ }^{25}$ Department of Environmental Toxicology, University of California, Davis, CA, USA

${ }^{26}$ Droplet Measurements Technologies, Boulder, CO, USA

${ }^{27}$ Chemical and Materials Sciences Division, Pacific Northwest National Laboratory, Richland, WA, USA

Correspondence to: R. A. Zaveri (rahul.zaveri@pnnl.gov)

Received: 5 December 2011 - Published in Atmos. Chem. Phys. Discuss.: 13 January 2012

Revised: 10 July 2012 - Accepted: 13 July 2012 - Published: 22 August 2012

Published by Copernicus Publications on behalf of the European Geosciences Union. 
Abstract. Substantial uncertainties still exist in the scientific understanding of the possible interactions between urban and natural (biogenic) emissions in the production and transformation of atmospheric aerosol and the resulting impact on climate change. The US Department of Energy (DOE) Atmospheric Radiation Measurement (ARM) program's Carbonaceous Aerosol and Radiative Effects Study (CARES) carried out in June 2010 in Central Valley, California, was a comprehensive effort designed to improve this understanding. The primary objective of the field study was to investigate the evolution of secondary organic and black carbon aerosols and their climate-related properties in the Sacramento urban plume as it was routinely transported into the forested Sierra Nevada foothills area. Urban aerosols and trace gases experienced significant physical and chemical transformations as they mixed with the reactive biogenic hydrocarbons emitted from the forest. Two heavily-instrumented ground sites - one within the Sacramento urban area and another about $40 \mathrm{~km}$ to the northeast in the foothills area - were set up to characterize the evolution of meteorological variables, trace gases, aerosol precursors, aerosol size, composition, and climaterelated properties in freshly polluted and "aged" urban air. On selected days, the DOE G-1 aircraft was deployed to make similar measurements upwind and across the evolving Sacramento plume in the morning and again in the afternoon. The NASA B-200 aircraft, carrying remote sensing instruments, was also deployed to characterize the vertical and horizontal distribution of aerosols and aerosol optical properties within and around the plume. This overview provides: (a) the scientific background and motivation for the study, (b) the operational and logistical information pertinent to the execution of the study, (c) an overview of key observations and initial findings from the aircraft and ground-based sampling platforms, and (d) a roadmap of planned data analyses and focused modeling efforts that will facilitate the integration of new knowledge into improved representations of key aerosol processes and properties in climate models.

\section{Introduction}

The strategy of the US Department of Energy for improving the treatments of atmospheric aerosol processes and properties in global climate models involves building up from the microscale with observational validation at every step (Ghan and Schwartz, 2007). Particular emphasis is placed on improving the scientific understanding of the possible interactions between various urban (anthropogenic) and natural (biogenic) emissions in aerosol formation and evolution of aerosol properties over a range of meteorological and chemical environments via an integrated approach of field, laboratory, and modeling studies. The Carbonaceous Aerosols and Radiative Effects (CARES) field campaign conducted in June 2010 in Sacramento, California, was a comprehen- sive effort designed to contribute toward accomplishing this goal. This paper provides an overview of the CARES project, and presents: (a) the scientific background and motivation for the field campaign, (b) the operational and logistical information pertinent to the execution of the campaign, (c) an overview of key observations and initial findings from the aircraft and ground-based sampling platforms, and (d) a roadmap of planned data analyses and focused modeling efforts that will facilitate the integration of new knowledge into improved representations of key aerosol processes and properties in regional and global climate-chemistry models.

Field observations show that ambient aerosol can be composed of a wide variety of compounds, including sulfate, nitrate, ammonium, sea salt, crustal species from soil dust, and carbonaceous materials (e.g., Murphy et al., 1998; Seinfeld and Pandis, 1998). Primary carbonaceous aerosols include black carbon (BC) particles mixed with varying amounts of organic compounds that are directly emitted from fossil fuel combustion, cooking, industrial processes, and biomass burning (agricultural burning and natural wildfires). Secondary carbonaceous aerosols, more commonly referred to as secondary organic aerosols (SOA), are those formed in the atmosphere via homogeneous nucleation, condensation, and heterogeneous reactions of myriad gas-phase oxidation products from numerous volatile and semi-volatile organic compounds of both anthropogenic and biogenic origins. Analyses of ambient aerosols in urban and rural areas have shown that carbonaceous compounds may constitute up to $90 \%$ of the dry non-refractory submicron particle mass (Kanakidou et al., 2005; Zhang et al., 2007).

Depending on their size and composition, aerosol particles can efficiently scatter and absorb solar radiation and serve as cloud condensation nuclei (CCN), thereby affecting climate (Forster et al., 2007). Significant progress has been made in the past two decades in representing the various inorganic and carbonaceous species in state-of-the-art aerosol models that include treatments for trace gas photochemistry, aerosol microphysics, aerosol thermodynamics, gas-particle mass transfer, and heterogeneous chemistry (e.g., Wexler and Seinfeld, 1991; Jacobson, 2002; Zhang et al., 2004; Bauer et al., 2008; Zaveri et al., 2008). However, substantial uncertainties still exist in our understanding of the evolution of organic and black carbon aerosols of both anthropogenic and biogenic origins and the associated optical and CCN activation properties. The CARES campaign was particularly motivated by three inter-related science questions:

1. How do anthropogenic and biogenic precursors interact to form SOA?

2. How rapidly does $B C$ mix with other species (especially SOA), and what are the relative contributions of condensation and coagulation to $\mathrm{BC}$ mixing state evolution? 
3. What are the effects of aerosol mixing state and organic (primary and secondary) species on the associated optical and $\mathrm{CCN}$ activation properties?

During summer, the Sacramento urban plume transport is controlled by consistent, thermally-driven upslope winds that draw polluted air to the northeast, into the Sierra Nevada foothills area rich in biogenic emissions (Dillon et al., 2002). As a result, the anthropogenic BC, primary organic aerosols (POA), SOA, and reactive trace gases from the Sacramento urban area undergo significant photochemical ageing as they mix with biogenic SOA precursors such as isoprene, monoterpenes, and related species. Some of these aged aerosols and trace gases could be transported back into the urban area by nighttime downslope flows. In this way, the Sacramento plume forms a natural chemical reactor useful for studying evolution of various carbonaceous and related aerosols. The CARES campaign observational strategy was designed to take advantage of this flow pattern by setting up two observation sites - one located within the Sacramento urban area, referred to as the "T0 site", and another located about $40 \mathrm{~km}$ to the northeast in Cool, CA, a small town in the foothills area, referred to as the "T1 site" (Fig. 1). Comprehensive measurement suites deployed at the $\mathrm{T} 0$ and $\mathrm{T} 1$ sites provided continuous information on the evolution of meteorological variables, trace gases, aerosol size, composition, optical properties, solar radiation, and $\mathrm{CCN}$ activation properties during the entire campaign period from 2-28 June. The ground measurements were complemented by a similar set of airborne measurements onboard the DOE Gulfstream-1 (G-1) aircraft, with flight plans involving sampling upwind, within, and outside of the evolving Sacramento urban plume in the morning and again in the afternoon. The NASA B-200 King Air aircraft, equipped with remote sensing instruments, was also deployed to characterize the vertical and horizontal distribution of aerosol optical properties and provide the vertical context for the G-1 and ground measurements.

The DOE CARES campaign overlapped temporally with the CalNex campaign in the Central Valley and Southern California regions in May and June 2010. CalNex was sponsored by the National Oceanic and Atmospheric Administration (NOAA) and the California Air Resources Board (CARB), and it focused on the atmospheric chemistry and meteorological processes that affect air quality and climate change issues both in California and nationally. The CalNex sampling platforms included the NOAA WP-3D and Twin Otter aircraft, the NOAA R/V Atlantis, and two ground sites in Southern California - one in Bakersfield and another in Los Angeles. The NOAA Twin Otter aircraft moved its operation from Southern California to Sacramento (McClellan Airfield) to collaborate with CARES from 14-28 June. It carried a combination of downward-looking ozone/aerosol and Doppler wind lidars and the scanning University of Colorado Airborne Multi-Axis DOAS (CU AMAX-DOAS) system to investigate $\mathrm{NO}_{\mathrm{x}}$ emission inventories and the 3-dimensional

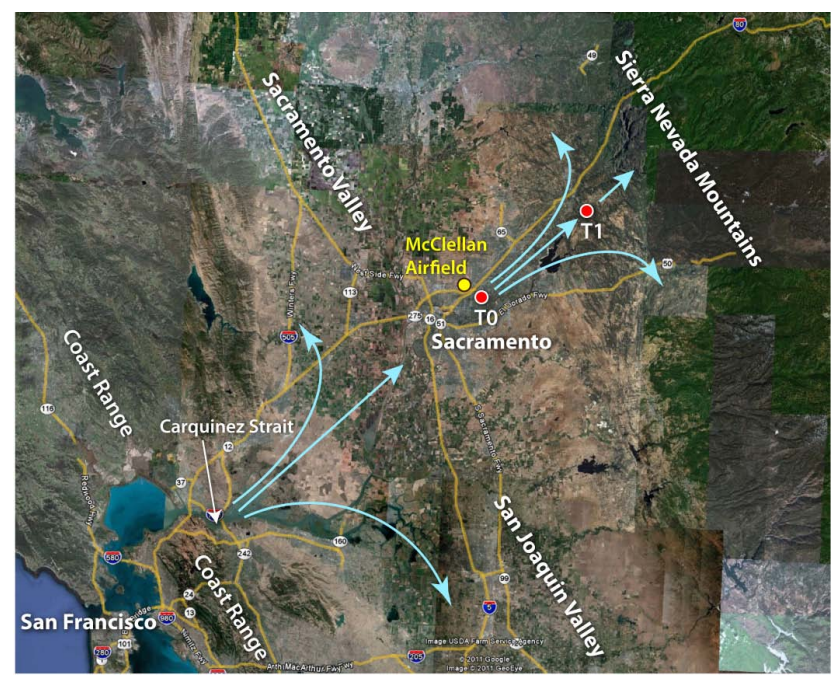

Fig. 1. Locations of the ground sites "T0" (latitude: 38.6483, longitude: -121.3493 , altitude: $\sim 30 \mathrm{~mm} . s .1$.) and "T1" (latitude: 38.8711, longitude: -121.0228 , altitude: $\sim 450 \mathrm{~mm}$. s.l.). Light blue arrows indicate typical daytime flow pattern in the region during summer.

distribution and transport processes of ozone and aerosols in the Central Valley.

The goal of this overview paper is to provide a coherent description of the project objectives, a campaign summary, and a context for mature scientific results that will be reported in future publications. We begin in Sect. 2 with a brief review of previous research related to the CARES science questions. In Sect. 3, we describe the campaign venue, sampling platforms (ground sites, aircraft), and the associated instruments and measurements. In Sect. 4, we present an overview of the key observations from the various airborne and ground-based instruments. In Sect. 5, we conclude with a summary of main initial findings and a roadmap for future work.

\section{Brief review of previous research related to CARES objectives}

\subsection{SOA formation and interactions between anthropogenic and biogenic emissions}

Several field studies have shown that SOA forms rapidly in urban plumes, with most of the SOA mass forming within the first $12 \mathrm{~h}$ (Volkamer et al., 2006; Kleinman et al., 2007; de Gouw et al., 2008). In contrast, modeling studies using Raoult's-Law-based schemes, parameterized using laboratory chamber SOA yield data, significantly under-predict SOA formation in the ambient urban atmosphere as well as in the upper troposphere (de Gouw et al., 2005; Heald et al., 2005; Johnson et al., 2006; Volkamer et al., 2006). In a more recent study, de Gouw et al. (2009) demonstrated that the growth of SOA at a suburban site in Mexico City could not 
be explained in terms of the measured volatile organic compounds (VOCs) and their chamber-based particulate mass yields and formation kinetics. Robinson et al. (2007) have suggested that some SOA mass at urban to regional scales may be produced by volatilization of high molecular weight semi-volatile and intermediate volatility organic compounds (SVOCs and IVOCs) from diesel exhaust primary organic aerosols (POA), followed by condensation of their oxidation products. Recent modeling efforts incorporating these and other previously missing SOA sources have begun to close the gap between predicted and measured SOA levels (Dzepina et al., 2009; Hodzic et al., 2010; Slowik et al., 2010; Lee-Taylor et al., 2011). However, comparisons of higherorder modeling endpoints to measurements, such as organic aerosol (OA) oxygen-to-carbon ratio $(\mathrm{O}: \mathrm{C})$, OA volatility, and ageing kinetics continue to indicate discrepancies in our understanding of SOA formation and atmospheric ageing (Dzepina et al., 2009; Hodzic et al., 2010; Lee-Taylor et al., 2011).

In addition to these discrepancies, results from field studies suggest that anthropogenic and biogenic emissions may somehow interact, resulting in increased overall yields of SOA. Weber et al. (2007) found that fine-particle water soluble organic carbon (WSOC) in aged urban plumes in the eastern United States was highly correlated with anthropogenic emissions from fossil fuel combustion. However, the carbon isotope $\left({ }^{14} \mathrm{C}\right)$ analysis of the WSOC samples indicated that roughly $70-80 \%$ of the carbon was of biogenic (modern) origin. Formation of organosulfate and organic nitrate compounds as a result of interactions between anthropogenic pollutants (e.g., sulfate, $\mathrm{NO}_{\mathrm{x}}$ ) and biogenic hydrocarbons (e.g., isoprene) has been suggested to contribute to SOA mass (Bruns et al., 2010; Farmer et al., 2010; Surratt et al., 2008, 2010; Zaveri et al., 2010a). In contrast, hydrophobic POA formed from fossil fuel combustion may not readily absorb oxidized (polar) biogenic hydrocarbons, as was previously assumed in many models, to enhance the overall SOA yields (Song et al., 2007). Many laboratory studies have implicated heterogeneous chemistry of semivolatile and volatile organic vapors within aqueous inorganic aerosols as a potential route for SOA formation from biogenic precursors (Jang et al., 2003; Kroll et al., 2005; Liggio et al., 2005, 2007; Limbeck et al., 2003). Also, accretion reactions, including aldol condensation, acid dehydration, and gem-diol condensation can transform volatile organic species into oligomeric products of low volatility (Gao et al., 2004; Jang et al., 2003; Kalberer et al., 2004; Tolocka et al., 2004), potentially increasing SOA mass beyond that predicted by Raoult's Law alone. Recent laboratory and field studies (including CARES) indicate that biogenic SOA particles may exist in amorphous solid form, in which case Raoult's Law may not even be applicable to calculate gas-particle partitioning of organic species on atmospherically relevant timescales (Vaden et al., 2011a; Virtanen et al., 2010).
One of the key instruments deployed during this and many previous campaigns for characterizing aerosol chemistry is the Aerodyne Aerosol Mass Spectrometer (AMS). The AMS provides real-time, quantitative, and size-resolved data on submicron aerosol composition with a time resolution of a few minutes or faster (Canagaratna et al., 2007). The HR-ToF-AMS, i.e., AMS built with a high-resolution time-of-flight mass spectrometer, is further able to determine the elemental ratios (e.g., oxygen-to-carbon, hydrogen-tocarbon, and nitrogen-to-carbon ratios) of aerosol-phase organics (Aiken et al., 2008). In addition, multivariate statistical analysis of AMS mass spectra is able to effectively determine organic aerosol factors representative of distinct sources and atmospheric processes (Zhang et al., 2005; Ulbrich et al., 2009). Recent studies have shown that comprehensive analyses of the mass spectra (i.e., chemical information) and temporal variation profiles of the OA factors, in conjunction with measurements of aerosol physics, tracer compounds, secondary aerosol precursors, and meteorological conditions, may reveal insights into organic aerosol lifecycle processes, such as SOA formation and evolution (Zhang et al., 2011).

While significant progress has been made on this topic, the physical and chemical interactions between anthropogenic and biogenic emissions leading to enhanced SOA formation remain poorly understood and are not represented well in regional and global atmospheric models. The CARES campaign observational strategy was designed to examine SOA formation at the urban (source) and rural (receptor) sites when the Sacramento urban plume mixed with biogenic emissions and when it did not. The comprehensive observations of precursor gases, aerosol composition, size distribution, etc. at the two sites and aboard the G-1 aircraft will be useful in constraining and evaluating SOA models designed to investigate the various possible physical and chemical interactions between anthropogenic and biogenic SOA precursors.

\subsection{Evolution of aerosol mixing state}

Amongst all the different types of primary and secondary aerosols present in the troposphere, BC (the refractory component of soot particles) is the most efficient and significant particulate absorber of solar radiation, and plays an important role in both regional- and global-scale climate forcing (Ramanathan et al., 2001; Jacobson, 2002, 2006; Bond, 2007; Levy et al., 2008). Freshly emitted soot particles consist of fractal-like chain agglomerates of primary soot spherules of 10 to $30 \mathrm{~nm}$ diameter (Wentzel et al., 2003). Ageing of soot particles by condensation of hygroscopic species such as sulfate, nitrate, and SOA typically leads to a compaction of the initially non-spherical chain agglomerate structures (Zhang et al., 2008; Tritscher et al., 2011), although coated yet noncompacted BC particles have also been observed in urban plumes (Adachi and Buseck, 2008). The mixing state and 
morphology of BC-containing particles is of particular interest from a climate change perspective, as a non-lightabsorbing coating on $\mathrm{BC}$ particles can increase the ensemble averaged absorption cross section of the $\mathrm{BC}$ core by up to a factor of 2 due to the focusing of light by the coating to the BC core (Lesins et al., 2002; Saathoff et al., 2003; Schnaiter et al., 2005; Bond et al., 2006; Adachi et al., 2010; Cross et al., 2010). The coating on BC particles also greatly increases their scattering cross sections, and the resulting single scattering albedo (i.e., the ratio of scattering cross section to the sum of scattering and absorption cross sections) is a function of the $\mathrm{BC}$ core size and the coating thickness. Hygroscopic coatings also dramatically affect the $\mathrm{CCN}$ activation properties and atmospheric lifetime of BC particles (Cantrell et al., 2001; Mochida et al., 2006; Kuwata et al., 2007; Medina et al., 2007; Cubison et al., 2008; Furutani et al., 2008; Tritscher et al., 2011).

Field studies of BC mixing state evolution with single particle soot photometer (SP2, Baumgardner et al., 2004; Schwarz et al., 2006; Moteki et al., 2007) reveal that BC particles tend to be thinly coated in urban areas, and become "thickly" coated as the urban plume undergoes photochemical ageing (Schwarz et al., 2008b; Subramanian et al., 2010). Several modeling studies have examined the roles of condensation and coagulation in transforming externally-mixed BC aerosols into internal mixtures (Fassi-Fihri et al., 1997; Jacobson, 2001, 2002; Jacobson et al., 1994; Strom et al., 1992). Recently, Riemer et al. (2008) developed and applied a stochastic particle-resolved aerosol box-model, PartMCMOSAIC, to an idealized urban plume scenario based on Los Angeles emissions, and the results indicate that $\mathrm{BC}$ particles have a wide range of mixing states after 12 to $24 \mathrm{~h}$ of processing. In a follow-on study, Zaveri et al. (2010b) found that aerosol optical, hygroscopic, and cloud activation properties can be sensitive to the aerosol mixing state even after 1 to 2 days of ageing. While field observations of evolution of $\mathrm{BC}$ mixing state are qualitatively consistent with the results from particle-resolved modeling studies, a quantitative validation of the detailed theoretical picture of aerosol mixing state evolution is necessary before a reliable, computationally efficient mixing state framework can be developed for use in regional and global climate models.

The SP2 instrument, when combined with the state-of-theart single particle mass spectrometer (SP-MS) instruments such as the single particle mass spectrometer (SPLAT II, Zelenyuk et al., 2009), Particle Analysis by Laser Mass Spectrometry (PALMS, Murphy and Thomson, 1997; Cziczo et al., 2006), and Aircraft-Aerosol Time-of-Flight Mass Spectrometer (A-ATOFMS, Pratt et al., 2009; Pratt and Prather, 2010), can provide a more complete picture of the different particle types and mixing states present in a population of aerosols. Recent advances in single particle characterizations have made it possible to extend the analysis of data to determine aerosol density, optical properties, shape, number concentrations, and size distributions (Murphy et al., 2004;
Moffet and Prather, 2005; Spencer et al., 2007; Zelenyuk et al., 2008; Zelenyuk and Imre, 2009; Vaden et al., 2011b) as well as combining data from other sources (or acquired while within clouds) to determine composition as a function of hygroscopicity and CCN activity (Buzorius et al., 2002; Herich et al., 2009; Kamphus et al., 2010; Zelenyuk et al., 2010; Hiranuma et al., 2011). Furthermore, offline analyses of field-collected aerosol samples can provide additional details on the composition, mixing state, and morphology of individual particles. These offline analytical techniques range from scanning electron microscopy (SEM) and microspectroscopy (STXM/NEXAFS) studies of individual particles (Laskin, 2010; Moffet et al., 2010a) to ultra-high resolution mass spectrometry analysis of individual components in OA material (Nizkorodov et al., 2011).

The CARES campaign included SP2 and SP-MS instruments as well as particle samplers (for offline analyses) at both ground sites and onboard the G-1 to characterize the evolution of aerosol mixing states in the Sacramento plume. The resulting composite picture of different particle types, size, composition, and morphology will be useful for constraining the particle-resolved aerosol model to evaluating the roles of condensation and coagulation in the evolution of aerosol mixing state, with a focus on $\mathrm{BC}$-containing particles.

\subsection{Aerosol optical properties}

As already discussed, the optical properties of freshly emitted and aged BC-containing particles can differ significantly. The mass absorption cross-section (MAC) of uncoated, pure $\mathrm{BC}$ is estimated to be $7.5 \pm 1.2 \mathrm{~m}^{2} \mathrm{~g}^{-1}$ for radiation of wavelength $\lambda=550 \mathrm{~nm}$ (Bond and Bergstrom, 2006). Laboratory studies and the "core-shell" Mie theory calculations show that ensemble average MAC of coated BC particles is amplified by up to a factor of $\sim 2$ (Schnaiter et al., 2005; Bond et al., 2006; Bueno et al., 2011). In addition to BC, organic compounds such as humic-like substances (HULIS) present in biomass burning aerosols also contribute to light absorption in the atmosphere (Mukai and Ambe, 1986; Havers et al., 1998; Hoffer et al., 2006; Lukacs et al., 2007). While light absorption by BC particles from diesel and motor vehicle soot typically displays an inverse dependence on wavelength, light absorbing organic carbon (LAOC) typically displays much stronger wavelength dependence. This increased absorption of light at wavelengths shorter than $600 \mathrm{~nm}$ causes the LAOC particles to appear brown (or yellow) (Bergstrom et al., 2002; Kirchstetter et al., 2004; Andreae and Gelencsér, 2006; Barnard et al., 2008; Gyawali et al., 2012). Furthermore, biomass burning particles composed of a small BC core $(\sim 50 \mathrm{~nm})$ and a thick coating of LAOC species may experience even larger enhancements in the absorption of light at wavelengths shorter than $600 \mathrm{~nm}$ (Gyawali et al., 2009).

Recent field measurements also indicate secondary sources of LAOC particulate matter that exhibit some 
chemical similarities to HULIS (Duarte et al., 2005; Marley et al., 2009; Hecobian et al., 2010). While the exact mechanisms for secondary LAOC formation in the ambient atmosphere are not fully understood, laboratory studies show that chromophores (components of molecules that absorb light) can form via a variety of heterogeneous chemical reactions, including ozonolysis of terpenes in the presence of ammonium ions (Bones et al., 2010) and isoprene oxidation in the presence of acidic solutions (Limbeck et al., 2003). Carbonyls such as glyoxal and methylglyoxal, produced from gas-phase photooxidation of many anthropogenic and biogenic VOCs, can also lead to the formation of LAOC material via heterogeneous reactions in acidic solutions (Noziere et al., 2007; Noziere and Esteve, 2005; Sareen et al., 2010), with amino acids (de Haan et al., 2009a; Noziere et al., 2007), methyl amines (de Haan et al., 2009b), and ammonium salts (Noziere et al., 2009; Sareen et al., 2010; Shapiro et al., 2009).

Thus, along with investigating SOA formation and aerosol mixing state evolution in the Sacramento urban plume, a major objective of CARES was to observe the evolution of aerosol light absorption and scattering in the near-UV and visible spectral regions as SOA of both anthropogenic and biogenic origin condensed (or formed via heterogeneous reactions) on urban BC particles and other, non-BC containing particles. Recent studies (Lack et al., 2008; Cappa et al., 2008) suggest that absorption measurements from filterbased instruments such as the Particle/Soot Absorption Photometer (PSAP) are suspect in the presence of OA. Photoacoustic and cavity ring-down spectroscopy instruments that bypass the filter problems and are useful for determining absorption coefficients in the visible region (Lewis et al., 2008; Radney et al., 2009). During CARES, the spectral ranges of these instruments were extended down to $\lambda=355 \mathrm{~nm}$ to specifically examine the absorption and scattering properties of OA.

\section{Design and measurements}

\subsection{Campaign venue and geography}

The CARES campaign was based in Sacramento, CA, and took place from 2-28 June 2010. Sacramento is located in California's expansive Central Valley, and is the sixth most populous city in California with a 2009 estimated population of 490 000. The seven-county Sacramento Metropolitan Area is the largest in the Central Valley, with an estimated population of 2.46 million. The western half of Greater Sacramento is agricultural area while the eastern portion of the region consists of the Sierra Nevada and its foothills, which are dominated by coniferous and oak forests. Figure 2 shows the spatial distribution of total anthropogenic VOCs and biogenic isoprene emissions in central California along with the locations of the T0 and T1 measurement supersites. The

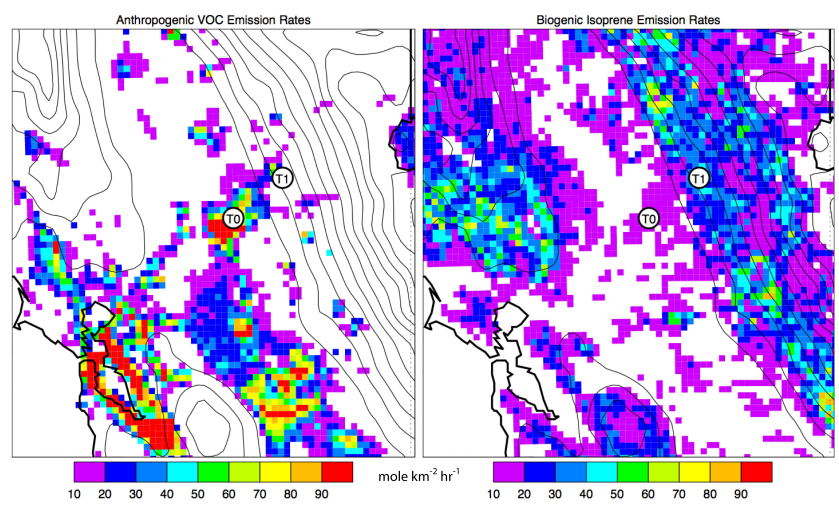

Fig. 2. Emission rates in the Central Valley at 11:00 PDT. Left panel: sum of all anthropogenic VOCs. Right panel: biogenic isoprene.

anthropogenic VOC emissions are from California Air Resources Board (CARB) emission inventory and the biogenic emissions are calculated online using MEGAN (Model of Emissions of Gases and Aerosols from Nature; Guenther et al., 2006).

The climate in Sacramento and the valley area is characterized by damp to wet, cool winters (October through April) and hot, dry summers (June through August). Summer heat is often moderated by a sea breeze, locally known as the "delta breeze", which comes from the San Francisco Bay through the Carquinez Strait (a narrow gap in the Coast Range) into the Sacramento-San Joaquin River Delta. While transport processes over the entire Central Valley can be complex (Bao et al., 2008), the local transport of the Sacramento urban plume during the summer is controlled by consistent, thermally-driven upslope winds that draw polluted air northeast over oak and pine trees in the Blodgett Forest area in the Sierra Nevada Mountains by late afternoon. The Sacramento-Blodgett Forest corridor effectively serves as a mesoscale flow reactor where the daily evolution of the Sacramento urban plume can be characterized as a Lagrangian air mass transported from the urban core into the sparsely populated Sierra Nevada Mountains (Dillon et al., 2002; Murphy et al., 2007). The CARES campaign observational strategy was designed to take advantage of this natural flow pattern by setting up the two observation sites - one located within the Sacramento urban area (site T0) and another located about $40 \mathrm{~km}$ to the northeast in Cool (site T1), a small town in the forested foothills of the Sierra Nevada Mountains.

\subsection{Ground sites and instruments}

The T0 site (latitude: 38.6483 , longitude: -121.3493 , altitude: $\sim 30 \mathrm{~mm}$.s.l.) was located in the campus of American River College, about $14 \mathrm{~km}$ northeast of the Sacramento downtown area. The T1 site (latitude: 38.8711, longitude: 
-121.0228 , altitude: $\sim 450 \mathrm{~mm}$.s.1.) was located on the property of the Northside School in Cool, California, situated amidst a forested area rich in biogenic emissions. The aged urban plume typically arrived at the $\mathrm{T} 1$ site around midto late-afternoon when ozone and SOA from urban and biogenic precursors were near their peak concentrations. The T0 and $\mathrm{T} 1$ ground sites thus characterized the diurnal evolution of meteorological variables, trace gases, aerosol precursors, and aerosol composition and properties in freshly polluted and aged urban air, respectively.

Nearly identical sets of measurements were made at both ground sites. Key measurements included trace gases, aerosol precursor gases, size-resolved particle concentration and chemical composition, particle physical properties (morphology, density, optical properties, hygroscopicity, and $\mathrm{CCN}$ activation), solar radiation measurements, and meteorological measurements. The measurement techniques, uncertainties, and time resolutions are summarized in Table 1. Two $40 \times 10 \mathrm{ft}$ trailers were set up at each site to house the instruments. The trailers were placed side by side, with the aerosol stack $(\sim 8 \mathrm{~m}$ high) erected between them, and inlet lines going into both trailers from the same stack. The trailer aerosol inlet system was based on the NOAA Global Monitoring Division (GMD) Aerosol Observing System (AOS) tower and inlet design (Delene and Ogren, 2002). The sample air was pulled through the stack and split into 2 components - an overall stack flow of $\sim 10001 \mathrm{~min}^{-1}$ and an aerosol flow $\left(\sim 1201 \mathrm{~min}^{-1}\right)$ through an internal concentric stainless steel tube $(\sim 5 \mathrm{~cm}$ OD). The lower end of the $5-\mathrm{cm}$ tube terminated in a 5-port manifold, four of which were $3 / 4$ - in stainless tubes and the fifth a $1 / 2$ - in tube (central flow for temperature and relative humidity measurements, as well as an auxiliary aerosol port for an Aerosol Particle Sizer, APS). Flow through the system was provided by a stand-alone pump box external to the trailers. Separate inlet lines were provided for trace gas and particle instruments. The trace gas inlet lines were Teflon and the particle inlet lines were made of stainless steel. One of the ports was connected to the AOS rack in one of the trailers. Two of the ports were used to provide aerosol flow to each of the trailers, respectively. Each inlet line coming into the trailer was further split (by a $3 / 4-$ in "Y") into lines that were wrapped around the internal walls of the trailer with $1 / 4$ - in pick-off ports strategically placed for the instrument configuration of each trailer. The return lines from these sampling manifolds were also attached to the pump box. The AOS rack had special return lines going to a carbon-vane pump and a diaphragm pump, respectively (also contained in the pump box).

The Washington State University mobile laboratory was also deployed at the T0 site and contained instruments for gas phase measurements. The inlet consisted of $1 / 2^{\prime \prime}$ PFA tubing that was mounted to a 10-m telescoping meteorology tower attached to the trailer. A Vaisala WXT-510 weather station was mounted on the top of the meteorology tower. Approximately $0.5 \mathrm{~m}$ below the weather station was the main inlet.
Approximately $321 \mathrm{~min}^{-1}$ of air was pulled through the inlet by a diaphragm pump with the flow measured by a TSI inline flow meter. Each instrument inside the trailer subsampled from this main inlet line. The $\mathrm{NO}_{\mathrm{xy}}$ instrument had a dedicated $\mathrm{NO}_{\mathrm{y}}$ converter inlet that was mounted about $1 \mathrm{~m}$ below the main inlet line.

The trace gas measurements included carbon monoxide $(\mathrm{CO})$, nitric oxide (NO), total reactive odd nitrogen species $\left(\mathrm{NO}_{\mathrm{y}}\right)$, and ozone $\left(\mathrm{O}_{3}\right)$. Nitrogen dioxide $\left(\mathrm{NO}_{2}\right)$ and sulfur dioxide $\left(\mathrm{SO}_{2}\right)$ analyzers were deployed at the T0 site (and on the G-1). Near surface $\mathrm{NO}_{2}$ mixing ratios and partial vertical column densities (VCD, integral over boundary layer height) were measured at $\mathrm{T} 1$ by the University of Colorado Ground Multi AXis DOAS instrument (CU GMAX-DOAS, Volkamer et al., 2009). Proton-Transfer Reaction Mass Spectrometers (PTR-MS) were used to measure mixing ratios of selected volatile organic compounds (VOC) of both anthropogenic and biogenic origin. The PTR-MS at T0 was modified to also characterize the total concentration of semivolatile long chain alkanes $\left(>\mathrm{C}_{10}\right)$ and heavier monoaromatics associated with diesel exhaust vapor emissions. The modification was to add a second inlet to the PTR-MS to allow in-situ thermal desorption sampling from a dedicated heat traced inlet. PTR-MS sampling alternated between thermal desorption analysis for diesel exhaust species and continuous de-humidified VOC sampling as described in Erickson et al. (2012). In addition, a gas chromatograph ion trap mass spectrometer (GC-ITMS) was used at T0 to measure selected $\mathrm{C}_{6}-\mathrm{C}_{10}$ VOCs to determine the abundance of SOA precursors such as monoaromatics emitted in vehicle exhaust and monoterpene compounds emitted from biogenic sources. Finally, near-surface concentrations of formaldehyde and glyoxal and VCDs were measured by CU GMAX-DOAS at T1 (Sinreich et al., 2010).

Condensation particle counters (CPC) were used to measure total particle number concentrations for particles larger than $10 \mathrm{~nm}$ diameter, and scanning mobility particle sizers (SMPS) and aerosol particle sizers (APS) were used to measure particle size distributions from 10 to $20000 \mathrm{~nm}$. The APS was placed directly below the inlet (i.e., at the bottom of the vertical column) where it drew air at a flow rate of 5 $1 \mathrm{~min}^{-1}$ of the 120 total $1 \mathrm{~min}^{-1}$. This placement prevented any bends in the tubing and thus minimized any inertial impaction losses of coarse particles. The "rain hat" on the top of the inlet stack is estimated to allow particles of at least $30000 \mathrm{~nm}$, although we did not actually characterize the inlet system on site for particle losses. An Aerodyne High Resolution Time-of-Flight Aerosol Mass Spectrometer (HR-ToFAMS), coupled to a thermal denuder (Fierz et al., 2007), was deployed at each ground site to measure aerosol composition and volatility distributions of submicron inorganic and organic aerosols. The HR-ToF-AMS uses an aerodynamic lens to sample submicron particles $(\sim 50-1000 \mathrm{~nm})$ into vacuum where they are aerodynamically sized, thermally vaporized on a heated surface $\left(\sim 600^{\circ} \mathrm{C}\right)$, and chemically analyzed via 
Table 1. Measurements and Instruments at the $\mathrm{T} 0$ and $\mathrm{T} 1$ Ground Sites.

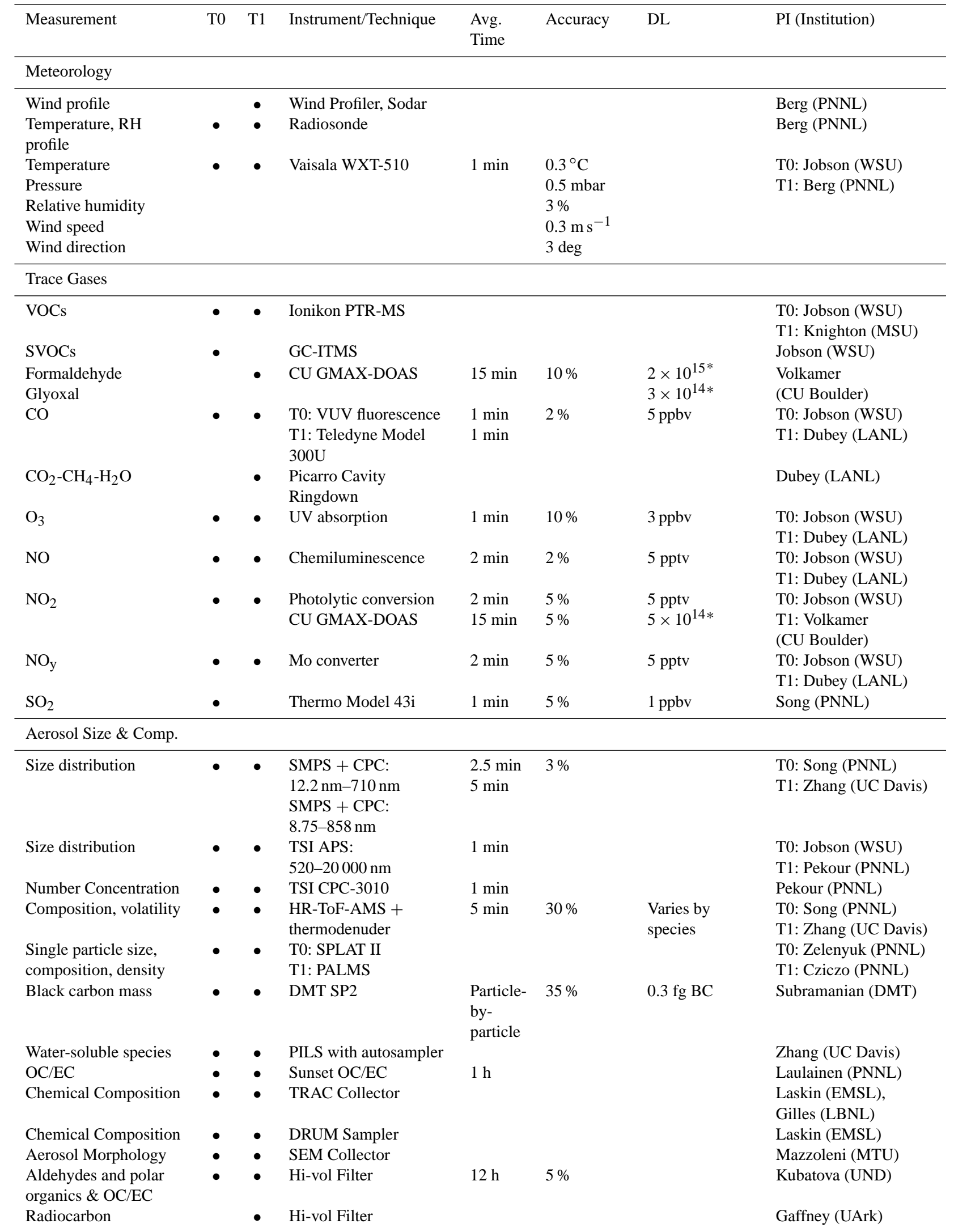


Table 1. Continued.

\begin{tabular}{|c|c|c|c|c|c|c|c|}
\hline Measurement & T0 & $\mathrm{T} 1$ & Instrument/Technique & $\begin{array}{l}\text { Avg. } \\
\text { Time }\end{array}$ & Accuracy & DL & PI (Institution) \\
\hline \multicolumn{8}{|l|}{ Radiation } \\
\hline$J-\mathrm{NO}_{2}$ & $\bullet$ & & $4 \pi J-\mathrm{NO}_{2}$ radiometer & $1 \mathrm{~s}$ & & & Laulainen (PNNL) \\
\hline Actinic flux & & & $\begin{array}{l}\text { Diode-Array Spectrora- } \\
\text { diometer }\end{array}$ & $1 \mathrm{~s}$ & & & Laulainen (PNNL) \\
\hline $\begin{array}{l}\text { Broadband solar rad } \\
\text { flux }\end{array}$ & $\bullet$ & $\bullet$ & $\begin{array}{l}\text { Pyranometer } \\
\text { (Eppley PSP) }\end{array}$ & $1 \mathrm{~min}$ & $4 \%$ & & Barnard (PNNL) \\
\hline $\begin{array}{l}\text { AOD from narrowband } \\
\text { solar irradiance }\end{array}$ & $\bullet$ & $\bullet$ & MFRSR & $20 \mathrm{~s}$ & $<0.01$ & & Barnard (PNNL) \\
\hline $\begin{array}{l}\text { Aerosol extinction pro- } \\
\text { files and AOD from } \\
\text { diffuse solar stray } \\
\text { light }\end{array}$ & & $\bullet$ & CU GMAX-DOAS & $15 \min$ & $\sim 0.01$ & & $\begin{array}{l}\text { Volkamer } \\
\text { (CU Boulder) }\end{array}$ \\
\hline \multicolumn{8}{|l|}{ Optical Properties } \\
\hline Scattering & $\bullet$ & & $\begin{array}{l}\text { TSI Nephelometer } \\
3563 \text { at } \\
450,550,700 \mathrm{~nm}\end{array}$ & $1 \mathrm{~min}$ & & $0.3 \mathrm{Mm}^{-1}$ & Pekour (PNNL) \\
\hline Absorption & $\bullet$ & $\bullet$ & $\begin{array}{l}\text { PSAP at } 470,532, \\
660 \mathrm{~nm}\end{array}$ & $1 \mathrm{~min}$ & & $0.3 \mathrm{Mm}^{-1}$ & Pekour (PNNL) \\
\hline Absorption & & $\bullet$ & Athelometer & & & & Sedlacek (BNL) \\
\hline $\begin{array}{l}\text { Absorption \& } \\
\text { scattering }\end{array}$ & $\bullet$ & $\bullet$ & $\begin{array}{l}\text { Photoacoustic } \\
\text { instruments } \\
\text { T0: } 375,405,532,781 \text {, } \\
870,1047 \mathrm{~nm} \\
\text { T1: } 355,405,532,781 \text {, } \\
870 \mathrm{~nm}\end{array}$ & & $\begin{array}{l}\text { Varies by } \\
\text { instrument } \\
\text { and } \lambda\end{array}$ & & $\begin{array}{l}\text { T0, T1: Arnott (UNR) } \\
\text { T0, T1: Dubey (LANL) } \\
\text { T0: Cappa (UCD) }\end{array}$ \\
\hline Extinction \& scattering & $\bullet$ & $\bullet$ & $\begin{array}{l}\text { Cavity Ring-down at } \\
355,405,532,1064 \mathrm{~nm}\end{array}$ & & $\begin{array}{l}\text { Varies by } \\
\text { instrument } \\
\text { and } \lambda\end{array}$ & & $\begin{array}{l}\text { T0, T1: Atkinson } \\
\text { (PSU) } \\
\text { T0: Cappa (UCD) }\end{array}$ \\
\hline Hygroscopic growth & $\bullet$ & $\bullet$ & Humidigraph - $f(\mathrm{RH})$ & & & & $\begin{array}{l}\text { T0: Cappa (UCD) } \\
\text { T1: Cziczo (PNNL) }\end{array}$ \\
\hline $\mathrm{CCN}$ & $\bullet$ & $\bullet$ & CCN Counter & & & & Cziczo (PNNL) \\
\hline $\mathrm{CCN}$ & & & $\begin{array}{l}\text { Size-resolved CCN } \\
\text { Counter }\end{array}$ & & & & Wang (BNL) \\
\hline
\end{tabular}

* Vertical Column Density (VCD); detection limit in units of molecule $\mathrm{cm}^{-2}$.

$70 \mathrm{eV}$ electron impact ionization time-of-flight mass spectrometry (Canagaratna et al., 2007). Since aerosol species must be vaporized to be detected, the HR-ToF-AMS does not measure refractory materials such as elemental carbon and dust particles. However, non-refractory (NR) materials internally mixed with refractory substances can be determined by the AMS and the presence of significant quantities of refractory particles can be detected via comparison between aerosol size distributions (from the SMPS or the AMS) and total mass detected, with appropriate assumptions about the particle density.

A Particle-Into-Liquid Sampler (PILS, Sooroshian et al., 2006) with an autosampler was deployed at each site to collect vials every hour for offline analysis of water soluble aerosol species. A $\mathrm{PM}_{1}$ impactor (BMI) was used upstream of the PILS, CCN, and HR-ToF-AMS. Droplet Measurement Technologies (DMT) Single Particle Soot Photometers
(SP2, Stephens et al., 2003; Schwarz et al., 2006) were used to measure single particle and ensemble black carbon mass loadings along with information on the amount of the particles' coatings and cores. Single particle mass spectrometers SPLAT II (Zelenyuk et al., 2009) and PALMS (Murphy and Thomson, 1997; Cziczo et al., 2006) were deployed at the T0 and T1 sites, respectively. A number of different impactors were also deployed at both sites to collect aerosol samples for offline analysis of particulate matter, ranging from electron microscopy and micro-spectroscopy studies of individual particles (Laskin, 2010; Moffet et al., 2010a) to ultra high resolution mass spectrometry analysis of individual components in OA material (Nizkorodov et al., 2011).

High-volume samplers (using brushless motors) equipped with slotted impactors were used at the $\mathrm{T} 1$ site to obtain sub-micron samples for carbon isotopic characterization using quartz fiber filters as described previously (Marley et al., 
2009). Another high-volume semi-volatile aerosol sampler was deployed at the T0 site from 2-15 June and at the T1 site from 16-28 June to collect particles of aerodynamic diameter $\leq 2.5 \mu \mathrm{m}\left(\mathrm{PM}_{2.5}\right)$ to study distribution of organic reactive species, particularly acids and aldehydes with respect to total organic carbon. Samples were collected for $12 \mathrm{~h}$ periods, from 08:00 a.m. to 08:00 p.m., and from 08:00 p.m. to 08:00 a.m. Half of each filter was spiked with recovery standards consisting of deuterated acids and aldehyde, derivatized using pentafluorobenzyl hydroxyl amine (PFBHA) in methanol to stabilize aldehydes, and stored at $-20^{\circ} \mathrm{C}$ in vials closed with Teflon stopper until the analysis. The other half of the filter was also stored at $-20^{\circ} \mathrm{C}$ without any modifications.

Aerosol optical properties were measured at multiple wavelengths with several techniques, including cavity ringdown spectroscopy for light extinction (CRDS, Smith and Atkinson, 2001; Radney et al., 2009; Langridge et al., 2011), photoacoustic spectroscopy for light absorption (PAS, Arnott et al., 1999; Lack et al., 2006), nephelometer for light scattering (Anderson et al., 1996), and particle soot absorption photometer (PSAP, Ogren, 2010). These measurements provide the absorption, scattering, and extinction coefficients as well as intensive (not dependent on aerosol concentration) properties such as the single scattering albedo and Ångström exponents, and depending on the particular operating procedures, their response to heating and changes in relative humidity. Additionally, enhancements in light absorption by aged BC were directly determined at the T0 site (from 15-29 June 2010) by measuring the absolute particulate absorption with the UC Davis PAS before and after passing the particles through a thermodenuder (TD). Similar measurements were also made onboard the R/V Atlantis from mid-May to midJune 2010 as part of the CalNex campaign. The extent of evaporation of semi-volatile species (internally mixed with $\mathrm{BC}$ ) depends on the TD temperature and the specific composition of the particles. Thus, if the coating on the $\mathrm{BC}$ particles causes an increase in the absorption, then thermally denuded $\mathrm{BC}$ particles would absorb less light than non-denuded BC particles, and the absorption enhancement $\left(E_{\mathrm{abs}}\right)$ can be calculated as the ratio of absorption measured before TD to that measured after TD.

Radiation observations at the ground sites included broadband solar fluxes as well as Multi-Filter Rotating Shadowband Radiometer (MFRSR, Harrison et al., 1994) measurements of downwelling visible and near-IR solar irradiance at six discrete wavelengths, which provide information needed to estimate aerosol optical depth and intensive properties. Partial column integrals over boundary layer height of aerosol extinction were observed at three wavelengths $(360 \mathrm{~nm}, 477 \mathrm{~nm}, 630 \mathrm{~nm})$ as inferred from solar stray light column observations of oxygen dimer by CU GMAX-DOAS (Volkamer et al., 2009; Sinreich et al., 2010).

Concentrations of $\mathrm{CCN}$ were measured at multiple supersaturations $(0.07$ to $0.5 \%)$ at both sites using Droplet Measurement Technologies CCN Counters (Model 200-013 and 100-081). The T1 site also included measurement of size-resolved CCN (SCCN) concentrations and variable relative humidity nephelometry (commonly referred to as $\mathrm{f}(\mathrm{RH})$ measurement). Finally, atmospheric state observations were made at the surface and aloft including wind speed and direction, pressure, temperature, and relative humidity at both sites using several instruments.

\subsection{Aircraft payloads}

The aircraft component of the CARES field campaign was based out of McClellan Airfield, located about $4 \mathrm{~km}$ northwest of the T0 ground site. The trace gas and aerosol measurements onboard the G-1 aircraft were similar to those deployed at the ground sites. The techniques, uncertainties, and time resolutions of all the G-1 measurements are summarized in Table 2. Trace gas measurements included $\mathrm{CO}$ (Kleinman et al., 2007), $\mathrm{NO}, \mathrm{NO}_{2}, \mathrm{NO}_{\mathrm{y}}, \mathrm{O}_{3}$, and $\mathrm{SO}_{2}$ (Springston et al., 2005). An Ionicon high-sensitivity quadrupole PTR-MS was used to measure VOCs. Condensation particle counters CPC3025 and CPC-3010 (Sem et al., 2002) were deployed to measure particle number concentrations for optical diameter $\left(D_{\mathrm{p}}\right)$ greater than 3 and $10 \mathrm{~nm}$, respectively. A combination of Fast Integrating Mobility Spectrometer (FIMS) (Kulkarni and Wang, 2006; Olfert et al., 2008), Ultra-High Sensitivity Aerosol Spectrometer-Airborne (UHSAS-A, Cai et al., 2008), and the Cloud Aerosol Spectrometer (CAS) portion of the Cloud Aerosol Precipitation Spectrometer (CAPS) probe (Baumgardner et al., 2001) were used to measure the particle size distribution for mobility diameters $\left(D_{\mathrm{m}}\right)$ between 30 and $70 \mathrm{~nm}$, and geometric diameters $\left(D_{\mathrm{g}}\right)$ between 60 and $1000 \mathrm{~nm}$, and 500 and $50000 \mathrm{~nm}$, respectively.

An Aerodyne HR-ToF-AMS was deployed to measure non-refractory aerosol components, a DMT SP2 was used to measure $\mathrm{BC}$ number and mass concentrations, and the AATOFMS was used to measure single-particle composition and mixing state. A PILS with an autosampler was deployed to collect vials every $3 \mathrm{~min}$ for offline analysis of water soluble aerosol species. Automated sampling of aerosol particles for microscopy and spectromicroscopy analyses was carried out using a Time-Resolved Aerosol Collector (TRAC, Laskin et al., 2006). Aerosol optical properties (scattering and absorption) at three wavelengths $(405,532$, and $781 \mathrm{~nm})$ were measured with an integrated PAS/nephelometer instrument (DMT PASS3) (Flowers et al., 2010), a TSI 3563 nephelometer (Anderson et al., 1996), and a Radiance Research PSAP (Ogren, 2010). The aerosol inlet on the G-1 allowed particles up to $5 \mu \mathrm{m}$ aerodynamic diameter with close to $100 \%$ transmission efficiency. Meteorological measurements included temperature, dew point, static pressure, and wind speed and direction.

The NASA B-200 King Air (B-200) aircraft deployed a High Spectral Resolution Lidar (HSRL) (Hair et al., 2008; Rogers et al., 2009) that measures aerosol backscatter ratio, backscatter and extinction coefficients, and depolarization. It 
Table 2. Measurements and Instruments aboard the DOE G-1 Aircraft during CARES 2010.

\begin{tabular}{|c|c|c|c|c|c|}
\hline Measurement & Instrument/Technique & Avg. Time & Accuracy & DL & PI (Institution) \\
\hline \multicolumn{6}{|l|}{ Meteorology } \\
\hline Temperature & Rosemount 102 & $1 \mathrm{~s}$ & $\pm 0.5^{\circ} \mathrm{C}$ & -50 to $50{ }^{\circ} \mathrm{C}$ & Hubbe (PNNL) \\
\hline Dewpoint temperature & $\begin{array}{l}\text { General Eastern 1011B chilled- } \\
\text { mirror hygrometer }\end{array}$ & $1 \mathrm{~s}$ & $\pm 0.5^{\circ} \mathrm{C}$ & -75 to $50^{\circ} \mathrm{C}$ & Hubbe (PNNL) \\
\hline Static pressure & Rosemount $1201 \mathrm{~F} 1$ & $1 \mathrm{~s}$ & $3 \mathrm{mb}$ & $400-1060 \mathrm{mb}$ & Hubbe (PNNL) \\
\hline Gust probe, alpha & All-Sensor 20-inch-G-4V & $0.1 \mathrm{~s}$ & $0.125 \mathrm{mb}$ & 0 to $50 \mathrm{mb}$ & Senum (BNL) \\
\hline Gust probe, beta & Rosemount 1221S1 & $0.1 \mathrm{~s}$ & $0.35 \mathrm{mb}$ & 0 to $35 \mathrm{mb}$ & Senum (BNL) \\
\hline Gust probe, dynamic & Rosemount 1221F2 & $1 \mathrm{~s}$ & $0.3 \mathrm{mb}$ & $\begin{array}{l}0 \text { to } 100 \mathrm{mb} \\
-55 \text { to } 71^{\circ} \mathrm{C}\end{array}$ & Hubbe (PNNL) \\
\hline \multicolumn{6}{|l|}{ Trace Gases } \\
\hline $\mathrm{CO}$ & $\begin{array}{l}\text { Resonance Limited } \\
\text { VUV-Fluorescence }\end{array}$ & $1 \mathrm{~s}$ & & & $\begin{array}{l}\text { Springston } \\
\text { (BNL) }\end{array}$ \\
\hline $\mathrm{SO}_{2}$ & TEI $43 \mathrm{~S}$ & $1 \mathrm{~s}$ & & & $\begin{array}{l}\text { Springston } \\
\text { (BNL) }\end{array}$ \\
\hline $\mathrm{O}_{3}$ & TEI $49-100$ & $1 \mathrm{~s}$ & & & $\begin{array}{l}\text { Springston } \\
\text { (BNL) }\end{array}$ \\
\hline $\mathrm{NO}, \mathrm{NO}_{2}$, and $\mathrm{NO}_{\mathrm{y}}$ & Research Grade Instruments & $1 \mathrm{~s}$ & & & $\begin{array}{l}\text { Springston } \\
\text { (BNL) }\end{array}$ \\
\hline VOCs & Ionikon PTR-MS & $3.5 \mathrm{~s}$ & $\begin{array}{l}\text { Varies by } \\
\text { species }\end{array}$ & $\begin{array}{l}\text { Varies by } \\
\text { species }\end{array}$ & $\begin{array}{l}\text { Shilling } \\
\text { (PNNL) }\end{array}$ \\
\hline \multicolumn{6}{|l|}{ Aerosol Size } \\
\hline Number conc. $>3 \mathrm{~nm}$ & TSI-3025 CPC & $1 \mathrm{~s}$ & & $0-10^{5} \mathrm{~cm}^{-3}$ & $\begin{array}{l}\text { Tomlinson } \\
\text { (PNNL) }\end{array}$ \\
\hline Number conc. $>10 \mathrm{~nm}$ & TSI-3010 CPC & $1 \mathrm{~s}$ & & $0-10^{4} \mathrm{~cm}^{-3}$ & $\begin{array}{l}\text { Tomlinson } \\
\text { (PNNL) }\end{array}$ \\
\hline $\begin{array}{l}\text { Particle size distribution } \\
\text { (PSD): } 30-70 \mathrm{~nm}\end{array}$ & FIMS & $1 \mathrm{~s}$ & & & Wang (BNL) \\
\hline PSD: $60-1000 \mathrm{~nm}$ & UHSAS-A & $1 \mathrm{~s}$ & & $0-7200 \mathrm{~cm}^{-3}$ & $\begin{array}{l}\text { Tomlinson } \\
\text { (PNNL) }\end{array}$ \\
\hline PSD: $500-50000 \mathrm{~nm}$ & CAPS/CAS & $1 \mathrm{~s}$ & & & Senum (BNL) \\
\hline \multicolumn{6}{|l|}{ Aerosol Composition } \\
\hline Aerosol composition & HR-ToF-AMS (EMSL) & $13 \mathrm{~s}$ & $\sim 30 \%$ & $\begin{array}{l}0.1 \mu \mathrm{g} \mathrm{m}^{-3} \\
\text { for org }\end{array}$ & $\begin{array}{l}\text { Shilling } \\
\text { (PNNL) }\end{array}$ \\
\hline $\begin{array}{l}\text { Single particle composition } \\
\text { and size }\end{array}$ & ATOFMS & & & & $\begin{array}{l}\text { Prather } \\
\text { (UCSD) }\end{array}$ \\
\hline Black carbon mass & DMT SP2 & $\begin{array}{l}\text { Particle-by- } \\
\text { particle }\end{array}$ & $\sim 35 \%$ & $0.3 \mathrm{fg} \mathrm{BC}$ & $\begin{array}{l}\text { Sedlacek } \\
\text { (BNL) }\end{array}$ \\
\hline $\begin{array}{l}\text { Water soluble aerosol } \\
\text { chemical composition }\end{array}$ & PILS with autosampler & $3 \min$ & $\begin{array}{l}\text { Varies by } \\
\text { species }\end{array}$ & $\begin{array}{l}0.02-0.28 \\
\mu \mathrm{g} \mathrm{m}^{-3} \\
\text { background }\end{array}$ & Zhang (UCD) \\
\hline $\begin{array}{l}\text { Aerosol chemical } \\
\text { composition }\end{array}$ & TRAC Collector & & & & $\begin{array}{l}\text { Laskin } \\
\text { (EMSL), } \\
\text { Gilles (LBNL) }\end{array}$ \\
\hline \multicolumn{6}{|l|}{ Optical Properties } \\
\hline Aerosol light scattering & $\begin{array}{l}\text { TSI } 3563 \text { Nephelometer at } \\
450,550 \text {, and } 700 \mathrm{~nm}\end{array}$ & $1 \mathrm{~s}$ & $4-7 \%$ & $1-10^{4} \mathrm{Mm}^{-1}$ & Hubbe (PNNL) \\
\hline Aerosol light absorption & $\begin{array}{l}\text { Radiance Research PSAP at } \\
461,522 \text {, and } 648 \mathrm{~nm}\end{array}$ & $1 \mathrm{~s}$ & $20 \%$ & $\begin{array}{l}10^{-1}- \\
10^{4} \mathrm{Mm}^{-1} \\
\text { (log channel); } \\
0-50 \mathrm{Mm}^{-1} \\
\text { (linear channel) }\end{array}$ & Hubbe (PNNL) \\
\hline $\begin{array}{l}\text { Aerosol light absorption } \\
\text { and scattering }\end{array}$ & $\begin{array}{l}\text { Photoacoustic spectrometer at } \\
405,532 \text {, and } 870 \mathrm{~nm}\end{array}$ & & & & Dubey (LANL) \\
\hline
\end{tabular}


Table 3. Measurements and Instruments aboard the NASA B-200 King Air Aircraft during CARES 2010.

\begin{tabular}{|c|c|c|c|c|}
\hline Parameter & Instrument/Technique & Averaging Time & $\begin{array}{l}\text { Uncertainty } \\
\text { or Accuracy }\end{array}$ & PI (Institution) \\
\hline Backscatter ratio $(532 \mathrm{~nm})$ & High Spectral Resolution Lidar & $10 \mathrm{~s}(\sim 1 \mathrm{~km})$ & $<5 \%$ & Ferrare, Hostetler (NASA) \\
\hline Backscatter coefficient (532 \& $1064 \mathrm{~nm})$ & High Spectral Resolution Lidar & $10 \mathrm{~s}(\sim 1 \mathrm{~km})$ & $0.16(\mathrm{Mm}-\mathrm{sr})^{-1}$ & Ferrare, Hostetler (NASA) \\
\hline Extinction coefficient $(532 \mathrm{~nm})$ & High Spectral Resolution Lidar & $1 \min (\sim 6 \mathrm{~km})$ & $10 \mathrm{Mm}^{-1}$ & Ferrare, Hostetler (NASA) \\
\hline Depolarization & High Spectral Resolution Lidar & $10 \mathrm{~s}(\sim 1 \mathrm{~km})$ & 0.004 & Ferrare, Hostetler (NASA) \\
\hline Aerosol optical depth & Research Scanning Polarimeter & scene-dependent ${ }^{\mathrm{d}}$ & $0.02 / 8 \% \mathrm{~b}$ & Cairns (NASA/GISS) \\
\hline Mode effective radius & Research Scanning Polarimeter & scene-dependent ${ }^{\mathrm{d}}$ & $0.02 \mu \mathrm{m} / 10 \%{ }^{\mathrm{c}}$ & Cairns (NASA/GISS) \\
\hline Mode effective variance & Research Scanning Polarimeter & scene-dependent ${ }^{\mathrm{d}}$ & $0.05 / 50 \%{ }^{\mathrm{c}}$ & Cairns (NASA/GISS) \\
\hline Real refractive index & Research Scanning Polarimeter & scene-dependent ${ }^{\mathrm{d}}$ & 0.02 & Cairns (NASA/GISS) \\
\hline Imaginary refractive index & Research Scanning Polarimeter & scene-dependent ${ }^{\mathrm{d}}$ & $50 \%$ & Cairns (NASA/GISS) \\
\hline
\end{tabular}

a See Hair et al. (2008) for a description of HSRL aerosol measurement uncertainties.

b The appropriate accuracy is whichever value is larger (i.e. lower accuracy at higher optical depths).

c Absolute accuracy applies to accumulation/fine mode and relative accuracy to coarse.

${ }^{\mathrm{d}}$ Scan rate is $1.1885 \mathrm{~Hz}(0.8414 \mathrm{~s})$, with angular resolution (instrument IFOV) equal to $14 \mathrm{mrad}$. The time required for scene aggregation is defined by the ratio of aircraft speed to target distance (see http://data.giss.nasa.gov/rsp_air/specs.html).

also carried a digital camera and the GISS Research Scanning Polarimeter (RSP). The latter instrument measures total and polarized reflectances in nine spectral bands across the visible and short-wave infrared portion of the electromagnetic spectrum. From these measurements, column-averaged aerosol optical (e.g., optical depth) and microphysical (e.g., refractive index and size distribution) parameters can be derived. The HSRL and RSP have been deployed together in several major field campaigns since 2008, in an effort to assess the potential of the synergistic exploitation of active and passive sensors in aerosol research (Waquet et al., 2009; Knobelspiesse et al., 2011; Ottaviani et al., 2011). The uncertainties and time resolutions of the B-200 measurements are summarized in Table 3.

As part of the CalNex field program, the NOAA Twin Otter aircraft moved its operation from Southern California to Sacramento (McClellan Airfield) to collaborate with CARES from 14-28 June. The NOAA Twin Otter was configured as a remote sensing platform carrying an ozone/aerosol lidar, a Doppler wind lidar, a scanning DOAS system, and several radiometers. The nadir-pointing Tunable Ozone Profiler for Aerosol and oZone (TOPAZ) lidar (Alvarez et al., 2011; Langford et al., 2011) measured ozone and aerosol backscatter profiles below the aircraft while the downward-looking, conically-scanned Doppler lidar (Pearson et al., 2009) provided measurements of horizontal and vertical winds. The zenith-to-nadir scanning University of Colorado Airborne Multi-AXis DOAS (CU AMAX-DOAS; Volkamer et al., 2009) instrument provided reactive trace gas column observations (i.e., nitrogen dioxide, aerosol extinction, formaldehyde and glyoxal) and the radiometers were used to measure surface albedo and surface skin temperature. These remote sensors were complemented by in situ measurements of ozone mixing ratio and temperature at flight level. The specifications for all instruments onboard the NOAA Twin Otter are listed in Table 4. This unique instrument package enabled the characterization of the horizontal and vertical structure of chemically and radiatively important trace gases and particulates within the boundary layer and lower free troposphere. The primary objectives of the NOAA Twin Otter deployment during CARES were the investigation of $\mathrm{NO}_{\mathrm{x}}$ emission inventories, and the mapping of the 3-D distribution and transport processes of ozone and aerosols in the Central Valley.

\subsection{Aircraft flights}

The Weather Research and Forecasting (WRF) model (Grell et al., 2005) was run daily at PNNL to provide 72-h forecasts of tracer plumes, which were used to guide aircraft operations and flight planning. The tracer plumes were based on $\mathrm{CO}$ emissions as well as meteorological parameters, using a horizontal grid spacing of $4 \mathrm{~km}$. The tracers were categorized into 20 sub-regions based on anthropogenic emissions source region that could impact the CARES sampling domain. Each forecast was made using the National Centers for Environmental Prediction's 00:00 UTC North American Mesoscale analysis and corresponding forecasts as initial and boundary conditions. Tracers were initialized with the previous day's forecasted tracer fields at 00:00 UTC. After the WRF forecast was completed, graphics depicting tracer positions at the surface and at select altitudes were generated automatically and made available on the CARES website (http://campaign.arm.gov/cares/forecast). Figure 3 shows examples of tracer forecasts (at 16:00 PDT) under southwesterly and northwesterly flows, which respectively occurred for 15 and 9 days out of the total 27 days from 2-28 June. More detailed analysis of the $\mathrm{CO}$ tracer forecasts and an analysis of them to categorize dominant transport scenarios during CARES can be found in Fast et al. (2012).

Table 5 summarizes pertinent details of all the aircraft flights carried out during CARES. The G-1 and B-200 aircraft performed a total of $22(67.5 \mathrm{~h})$ and $23(68 \mathrm{~h})$ research flights, respectively, while the NOAA Twin Otter performed 
Table 4. Measurements and Instruments aboard the NOAA Twin Otter Aircraft during CARES 2010.

\begin{tabular}{|c|c|c|c|c|c|c|}
\hline Parameter & $\begin{array}{l}\text { Instrument/ Tech- } \\
\text { nique }\end{array}$ & Avg. Time & $\begin{array}{l}\text { Vertical/Range } \\
\text { Resolution }\end{array}$ & $\begin{array}{l}\text { Measurement } \\
\text { Precision }\end{array}$ & $\begin{array}{l}\text { Measurement } \\
\text { Accuracy }\end{array}$ & PI (Institution) \\
\hline Ozone profiles & $\begin{array}{l}\text { Differential } \\
\text { Absorption Lidar }\end{array}$ & $\begin{array}{l}10 \mathrm{~s} \\
(\sim 600 \mathrm{~m})\end{array}$ & $\begin{array}{l}90 \mathrm{~m} \\
\text { (smoothed over } \\
450 \mathrm{~m} \text { ) }\end{array}$ & $\begin{array}{l}5-10 \% \text { (up to } \\
30 \% \text { for low } \\
\text { SNR) }\end{array}$ & $\begin{array}{l}<5 \% \text { (up to } \\
15 \% \text { for low } \\
\text { SNR) }\end{array}$ & $\begin{array}{l}\text { Senff (NOAA/CU } \\
\text { Boulder }\end{array}$ \\
\hline $\begin{array}{l}\text { Aerosol backscatter } \\
\text { profiles }(300 \mathrm{~nm})\end{array}$ & $\begin{array}{l}\text { Differential } \\
\text { Absorption Lidar }\end{array}$ & $\begin{array}{l}10 \mathrm{~s} \\
(\sim 600 \mathrm{~m})\end{array}$ & $6 \mathrm{~m}$ & $\sim 10 \%$ & $<30 \%$ & $\begin{array}{l}\text { Senff (NOAA/CU } \\
\text { Boulder }\end{array}$ \\
\hline $\begin{array}{l}\text { Boundary layer } \\
\text { height }\end{array}$ & $\begin{array}{l}\text { Differential } \\
\text { Absorption Lidar }\end{array}$ & $\begin{array}{l}10 \mathrm{~s} \\
(\sim 600 \mathrm{~m})\end{array}$ & - & $\sim 50 \mathrm{~m}$ & $\sim 50 \mathrm{~m}$ & $\begin{array}{l}\text { Senff (NOAA/CU } \\
\text { Boulder }\end{array}$ \\
\hline $\begin{array}{l}\text { Line-of-sight wind } \\
\text { speed profiles (at } 4 \\
\text { azimuth angles) }\end{array}$ & Doppler Lidar & $\begin{array}{l}2-6 \mathrm{~s} \\
(\sim 240 \mathrm{~m})\end{array}$ & $50 \mathrm{~m}$ & $0.1 \mathrm{~m} \mathrm{~s}^{-1}$ & up to $0.1 \mathrm{~m} \mathrm{~s}^{-1}$ & Hardesty (NOAA) \\
\hline $\begin{array}{l}\text { Relative aerosol } \\
\text { backscatter profiles } \\
(1.6 \mu \mathrm{m})\end{array}$ & Doppler Lidar & $\begin{array}{l}1 \mathrm{~s} \\
(\sim 60 \mathrm{~m})\end{array}$ & $50 \mathrm{~m}$ & Uncalibrated & Uncalibrated & Hardesty (NOAA) \\
\hline $\begin{array}{l}\mathrm{NO}_{2} \text { vertical } \\
\text { column density } \\
(\mathrm{VCD})\end{array}$ & $\begin{array}{l}\text { CU Airborne Multi } \\
\text { AXis DOAS }\end{array}$ & $\begin{array}{l}2 \mathrm{~s} \\
(\sim 1 \mathrm{~km})\end{array}$ & - & $\begin{array}{l}\sim 10 \% \text { (up to } \\
30 \% \text { at high so- } \\
\text { lar zenith } \\
\text { angle) }\end{array}$ & $\begin{array}{l}1.5 \times 10^{15} \\
\text { molec cm }\end{array}$ & $\begin{array}{l}\text { Volkamer } \\
\text { (CU Boulder) }\end{array}$ \\
\hline $\begin{array}{l}\mathrm{NO}_{2}, \mathrm{HCHO}, \\
\mathrm{CHOCHO} \text { vertical } \\
\text { profiles }\end{array}$ & $\begin{array}{l}\text { CU Airborne Multi } \\
\text { AXis DOAS }\end{array}$ & ascent/descent & $\sim 150 \mathrm{~m}$ & $\sim 10 \%$ & $\begin{array}{l}\text { Depends on gas } \\
\text { and averaging } \\
\text { time }\end{array}$ & $\begin{array}{l}\text { Volkamer } \\
\text { (CU Boulder) }\end{array}$ \\
\hline $\begin{array}{l}\text { Aerosol extinction } \\
\text { profiles }(360 \mathrm{~nm} \text {, } \\
477 \mathrm{~nm}, 630 \mathrm{~nm})\end{array}$ & $\begin{array}{l}\text { CU Airborne Multi } \\
\text { AXis DOAS }\end{array}$ & ascent/descent & $\sim 150 \mathrm{~m}$ & - & $\begin{array}{l}\sim 0.01- \\
0.03 \mathrm{~km}^{-1} \\
\text { (varies at } \\
\text { different } \\
\text { wavelengths) }\end{array}$ & $\begin{array}{l}\text { Volkamer } \\
\text { (CU Boulder) }\end{array}$ \\
\hline $\begin{array}{l}\text { Ozone (at flight } \\
\text { level) }\end{array}$ & UV light absorption & $\begin{array}{l}10 \mathrm{~s} \\
(\sim 600 \mathrm{~m})\end{array}$ & - & $1 \mathrm{ppbv} / 2 \%$ & $1 \mathrm{ppbv} / 2 \%$ & Langford (NOAA) \\
\hline $\begin{array}{l}\text { Temperature (at } \\
\text { flight level) }\end{array}$ & & $\begin{array}{l}1 \mathrm{~s} \\
(\sim 60 \mathrm{~m})\end{array}$ & - & $0.1 \mathrm{~K}$ & $0.1 \mathrm{~K}$ & $\begin{array}{l}\text { Senff (NOAA/CU } \\
\text { Boulder }\end{array}$ \\
\hline $\begin{array}{l}\text { Surface } \\
\text { temperature }\end{array}$ & IR pyrometer & $\begin{array}{l}1 \mathrm{~s} \\
(\sim 60 \mathrm{~m})\end{array}$ & - & $0.06 \mathrm{~K}$ & $0.5 \mathrm{~K}$ & $\begin{array}{l}\text { Senff (NOAA/CU } \\
\text { Boulder }\end{array}$ \\
\hline Surface albedo & $\begin{array}{l}\text { 4-channel UV and } \\
\text { vis irradiance }\end{array}$ & $\begin{array}{l}30 \mathrm{~s} \\
(\sim 1.8 \mathrm{~km})\end{array}$ & - & $\sim 5 \%$ & $\sim 5 \%$ & $\begin{array}{l}\text { Volkamer (CU } \\
\text { Boulder) }\end{array}$ \\
\hline
\end{tabular}

17 flights $(60 \mathrm{~h})$. The G-1 flight plans included several patterns that were designed for a specific purpose or the given wind flow condition. These patterns can be grouped into 3 basic types of missions: (1) morning or afternoon flight plan designed to characterize the inflow from the Bay Area under southwesterly flow; (2) morning and afternoon flight plans designed to characterize the evolution of the Sacramento urban plume under southwesterly flow; (3) morning and afternoon flight plans designed to characterize the evolution of the Sacramento urban plume under northwesterly flow. A late morning flight was also conducted on 27 June to characterize isoprene emission flux over the Sierra Nevada foothills region.

The B-200 flew at an altitude of approximately $7 \mathrm{~km}$ above ground, with most flights coordinated with the G-1 to characterize the vertical and horizontal distribution of aerosol optical properties and provide the vertical context for the G-1 and ground measurements. B-200 also sampled over a larger area than the G-1 so that the G-1 observations could be interpreted within the larger spatial context. Figure 4 shows the G-
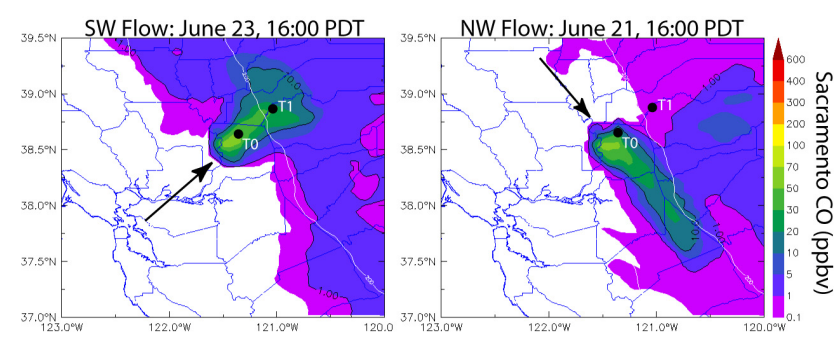

Fig. 3. Examples of tracer forecasts, based on $\mathrm{CO}$ emitted from Sacramento, shown at 16:00 PDT under southwesterly (left panel) and northwesterly wind (right panel) flow conditions.

1 and B-200 flight tracks grouped according to the type of the mission based on the expected transport scenario from WRF tracer forecast. Additional missions flown by the G-1 and B200, not shown here, included coordination with R/V Atlantis that moved along the Sacramento Deep Water Channel from San Francisco Bay on 3 June and an intercomparison flight 
Table 5. Summary of DOE G-1, NASA-B200, and NOAA Twin Otter aircraft flights in the CARES domain during the month of June 2010.

\begin{tabular}{|c|c|c|c|c|c|}
\hline Date & $\begin{array}{l}\text { DOE G-1 } \\
\text { Takeoff - } \\
\text { Landing } \\
\text { PDT }\end{array}$ & $\begin{array}{l}\text { NASA B-200 } \\
\text { Takeoff - } \\
\text { Landing } \\
\text { PDT }\end{array}$ & $\begin{array}{l}\text { NOAA Twin } \\
\text { Otter } \\
\text { Takeoff - } \\
\text { Landing } \\
\text { PDT }\end{array}$ & Wind Dir & Remarks \\
\hline 3 June & $12: 41-15: 07$ & $12: 24-15: 49$ & - & SW & $\begin{array}{l}\text { Coordinated with R/V Atlantis; very } \\
\text { low AOD throughout region }\end{array}$ \\
\hline 5 June & - & $11: 29-13: 43$ & - & SW & $\begin{array}{l}\text { B-200 flew survey over SAC, northern } \\
\text { SJV, and SF/Bay area. }\end{array}$ \\
\hline 6 June & $\begin{array}{l}10: 35-13: 43 \\
15: 35-18: 20\end{array}$ & $09: 26-12: 24$ & - & SW & Very low AOD and shallow PBL. \\
\hline 8 June & $\begin{array}{l}08: 55-12: 12 \\
15: 24-18: 47\end{array}$ & $\begin{array}{l}08: 54-12: 10 \\
14: 35-17: 56\end{array}$ & - & SW & B-200 legs also over Bay area \\
\hline 10 June & $15: 36-18: 31$ & $14: 31-17: 56$ & - & NW & $\begin{array}{l}\text { B-200 flew over SAC and also over } \\
\text { Sierra Nevada mountains for RSP snow } \\
\text { measurements }\end{array}$ \\
\hline 12 June & $\begin{array}{l}08: 55-11: 59 \\
15: 24-18: 28\end{array}$ & $\begin{array}{l}09: 08-12: 40 \\
15: 05-17: 50\end{array}$ & - & NW & $\begin{array}{l}\text { B-200 legs also over northern SJV } \\
\text { and SF/Bay Area. HSRL observed high } \\
\text { aerosol depolarization associated with } \\
\text { dust. }\end{array}$ \\
\hline 14 June & $09: 56-13: 10$ & $\begin{array}{l}10: 09-13: 42 \\
15: 18-18: 00\end{array}$ & - & SW & $\begin{array}{l}\text { Bay Area inflow; B200 flew two flights } \\
\text { and covered regions between SF/Bay } \\
\text { area and SAC. Second B200 flight flew } \\
\text { over NOAA P3 track. }\end{array}$ \\
\hline 15 June & $\begin{array}{l}08: 56-12: 00 \\
14: 51-18: 07\end{array}$ & $\begin{array}{l}09: 09-12: 23 \\
14: 39-18: 02\end{array}$ & $\begin{array}{l}11: 52-15: 12 \\
16: 15-19: 15\end{array}$ & SW & $\begin{array}{l}\text { B-200 legs over SF/Bay area, SAC, and } \\
\text { mountains east of SAC. Inflow from } \\
\text { SF/Bay area. Highest AOD over SAC. }\end{array}$ \\
\hline 18 June & $15: 38-18: 48$ & $15: 19-18: 53$ & $\begin{array}{l}12: 36-15: 39 \\
16: 40-20: 10\end{array}$ & SW & $\begin{array}{l}\text { Intercomparison between G-1, NOAA } \\
\text { WP-3, B-200, and NOAA TO from } \\
\text { Fresno to Bakersfield. }\end{array}$ \\
\hline 19 June & $15: 28-18: 31$ & $\begin{array}{l}09: 46-11: 52 \\
15: 32-18: 33\end{array}$ & - & SW & $\begin{array}{l}\text { B-200 also flew over mountains east } \\
\text { of SAC. HSRL observed elevated dust } \\
\text { layer } 5-8 \mathrm{~km} \text {. }\end{array}$ \\
\hline 21 June & $\begin{array}{l}09: 02-12: 11 \\
15: 25-18: 44\end{array}$ & $15: 32-18: 52$ & $\begin{array}{l}10: 05-13: 50 \\
15: 15-18: 40\end{array}$ & NW & $\begin{array}{l}\text { NOAA TO coordinated with OMI } \\
\text { satellite* }^{*}\end{array}$ \\
\hline 22 June & - & 14:08-16:16 & $\begin{array}{l}08: 20-11: 27 \\
13: 39-17: 12\end{array}$ & $\mathrm{~W}$ & $\begin{array}{l}\text { B-200 and NOAA TO flew coordinated } \\
\text { flight for long range transport. }\end{array}$ \\
\hline 23 June & $\begin{array}{l}09: 34-12: 51 \\
14: 24-18: 12\end{array}$ & $\begin{array}{l}09: 51-12: 01 \\
14: 52-17: 09\end{array}$ & $14: 40-17: 55$ & SW & $\begin{array}{l}\text { HSRL observed elevated layers and } \\
\text { clouds over SAC. NOAA TO } \\
\text { coordinated with OMI satellite* }\end{array}$ \\
\hline 24 June & $\begin{array}{l}09: 00-12: 16 \\
14: 24-18: 12\end{array}$ & $14: 56-17: 45$ & $\begin{array}{l}09: 42-13: 15 \\
15: 12-18: 55\end{array}$ & SW & $\begin{array}{l}\text { Bay Area Inflow; HSRL observed } \\
\text { considerable midlevel clouds over SAC }\end{array}$ \\
\hline 26 June & - & - & $15: 15-19: 03$ & SW & \\
\hline 27 June & $10: 24-13: 47$ & 09:19-12:25 & $\begin{array}{l}09: 37-13: 32 \\
15: 15-19: 02\end{array}$ & SW & $\begin{array}{l}\text { Isoprene flux flight to the northeast over } \\
\text { the foothills area: B-200 had leg over } \\
\text { SF/Bay Area. Highest AOD over SAC } \\
\text { region. }\end{array}$ \\
\hline 28 June & $\begin{array}{l}09: 23-12: 33 \\
14: 20-17: 42\end{array}$ & $\begin{array}{l}10: 10-13: 20 \\
15: 56-18: 18\end{array}$ & $10: 15-14: 06$ & W & $\begin{array}{l}\text { MISR Overpass, highest pollution and } \\
\text { AOD day of the campaign. Largest } \\
\text { AOD over SAC, observed SAC plume } \\
\text { in AOD. NOAA TO coordinated with } \\
\text { OMI satellite* }\end{array}$ \\
\hline 29 June & - & - & $\begin{array}{l}08: 00-11: 10 \\
12: 29-16: 17\end{array}$ & & $\begin{array}{l}\text { Bakersfield } \mathrm{NO}_{\mathrm{x}} \text { emission inventory, } \\
\text { San Francisco, San Joaquin Valley }\end{array}$ \\
\hline Total & 21 & 23 & 17 & & \\
\hline
\end{tabular}

* $\mathrm{NO}_{2}$ tropospheric VCD are measured by the OMI instrument onboard the NASA Aura satellite. Global coverage is achieved within one day. 


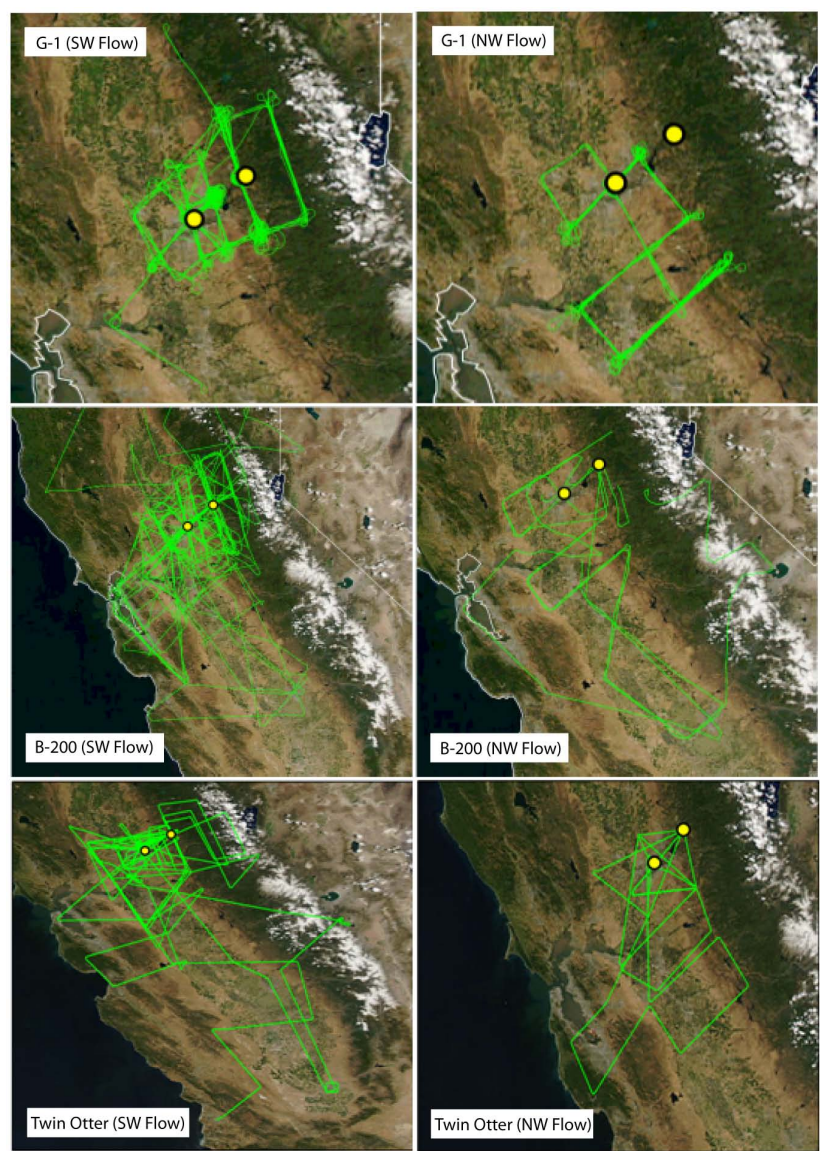

Fig. 4. DOE G-1, NASA B-200, and NOAA Twin Otter Flight Tracks during the SW and NW flow periods. The yellow circles indicate the locations of the $\mathrm{T} 0$ and $\mathrm{T} 1$ ground sites.

with the NOAA WP-3D on 18 June in the San Joaquin Valley, from Fresno to Bakersfield, CA.

While the NOAA Twin Otter flights were not closely coordinated with the G-1 or the B-200, they were mostly in the same general area, with some flights extending over a larger domain (Fig. 4). The main objective was to sample the greater Sacramento area extensively, including regular overpasses over the T1 site. The Twin Otter flew morning and afternoon missions, typically lasting $3-4 \mathrm{~h}$. The morning flights were generally focused on investigating $\mathrm{NO}_{\mathrm{x}}$ emissions whereas the afternoon flights were designed to characterize ozone distribution and transport downwind of Sacramento and the Bay Area. Flight altitudes varied from 600 to $5000 \mathrm{~m}$ m.s.l. Another objective was the detection and characterization of pollution plumes transported from Asia.

\section{Overview of observations}

\subsection{Meteorological context of CARES}

An overview of meteorology during CARES is provided by Fast et al. (2012). Here we give a brief summary of the meteorological conditions that prevailed during the study period. During late May the Central Valley experienced strong northwesterly flow and precipitation events, which were likely due to the lingering effects of the moderate El Nino that occurred in early 2010. The campaign thus began with cooler than normal temperatures and intermittent cloudiness through 6 June, followed by mostly sunny days for the remainder of the campaign. Figure 5 displays the time series of wind direction, wind speed, temperature $(T)$, and relative humidity $(\mathrm{RH})$ at the $\mathrm{T} 0$ and $\mathrm{T} 1$ sites. The wind direction at both sites during the daytime was typically southwesterly to westerly, favoring transport of the Sacramento urban plume to the T1 site area by late afternoon or early evening. For the days labeled $\mathrm{SW}$, the wind direction at $\mathrm{T} 0$ typically shifted to southerly by 18:00 PDT and to southeasterly by midnight, bringing relatively cleaner background air into the urban area. In contrast, the wind direction at the $\mathrm{T} 1$ site typically experienced a reversal from westerly (upslope) in the afternoon to easterly or northeasterly (downslope) at night, gradually recirculating the air mass in the foothills region back into the valley in the residual layer by next morning.

Days with synoptic southwesterly (SW) flow were generally favorable for transporting the urban plume from Sacramento to the T1 site and vicinity. These days include: $2-4$, $6-9,14-15,17-19$, and $23-28$ June. The period from 22 to 28 June also experienced a steady buildup of aged pollutants (particularly of organic aerosols as shown in Sect. 4.3) due to more pronounced recirculation of pollutants coupled with warmer temperatures toward the end of June. These conditions resulted in the highest pollution days (25-28 June) at the end of the campaign. Observations across the cleaner periods in the beginning of the campaign and the relatively more polluted periods towards the end will thus provide an exceptional opportunity to examine aerosol formation and evolution processes in the same region under a range of environmental conditions.

The SW wind pattern was interrupted by northwesterly (NW) flows three times during the campaign: 10-13, 16, and 20-21 June. During these NW flow events the Sacramento urban plume was transported to the southeast along San Joaquin Valley, with relatively less mixing with biogenic emissions when compared to SW flow events. Conversely, the biogenic emissions at and around the $\mathrm{T} 1$ site were not significantly influenced by urban emissions during the NW flow periods. This contrasting feature between the SW and NW flow events will be valuable in investigating the role of anthropogenic-biogenic interactions in SOA formation from each source type. The SW and NW flow periods are respectively identified with green and orange bars 


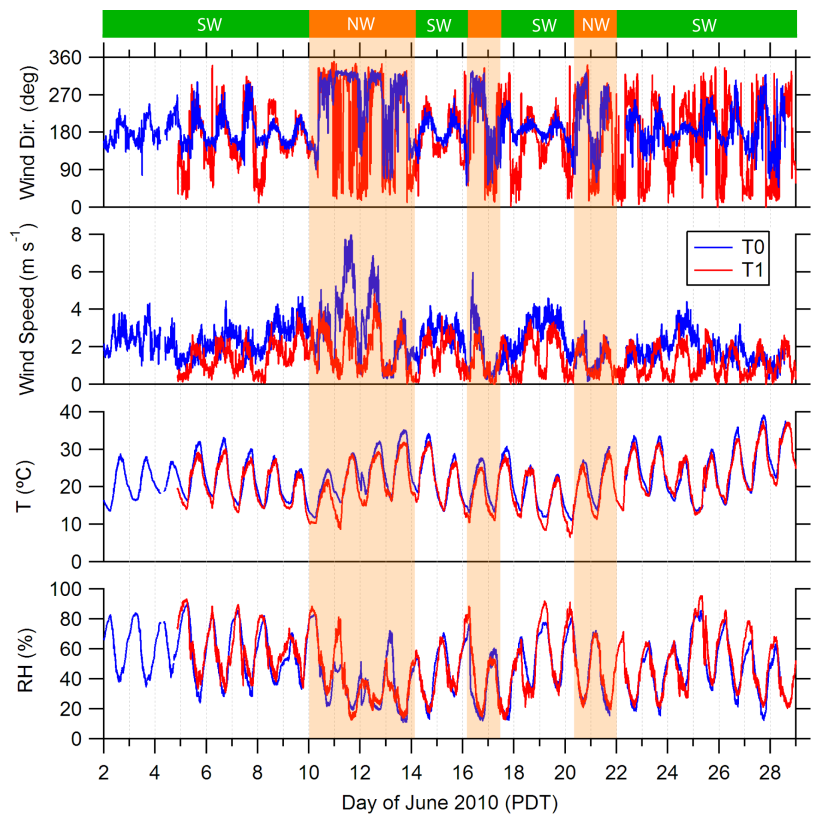

Fig. 5. Time series of standard meteorological variables at the T0 and $\mathrm{T} 1$ ground sites. The green-orange bar at the top indicates periods during which the synoptic wind was either southwesterly (SW) or northwesterly (NW). Semi-transparent orange shading for the NW flow periods is also shown over all the plots.

at the top in Fig. 5 (and subsequent figures showing time series of other variables), with semi-transparent orange shading shown through all the plots for the NW flow periods.

The wind speeds at both $\mathrm{T} 0$ and $\mathrm{T} 1$ sites were generally small $\left(<4 \mathrm{~m} \mathrm{~s}^{-1}\right)$, with large values occurring around noon and the smallest values around midnight. Diurnal variations in surface temperatures at the $\mathrm{T} 0$ and $\mathrm{T} 1$ sites were similar, with highs between 25 and $35^{\circ} \mathrm{C}$ occurring around 18:00 PDT and lows between 10 and $15^{\circ} \mathrm{C}$ occurring around 06:00 PDT. Due to the higher elevation of the T1 site, the air was usually a few degrees $\left(0\right.$ to $\left.5^{\circ} \mathrm{C}\right)$ cooler at $\mathrm{T} 1$ than at $\mathrm{T} 0$. The last three days (26-28 June) were the warmest of the entire campaign, with temperatures at $\mathrm{T} 0$ reaching a maximum of $39^{\circ} \mathrm{C}$ on 27 June. Relative humidity displayed an opposite diurnal behavior compared to temperature, with highs between 70 and $90 \%$ occurring at 06:00 PDT and lows of about $20 \%$ occurring around 18:00 PDT.

\subsection{Trace gases observations}

Figure 6 shows comparisons of the time series of key trace gases $\left(\mathrm{SO}_{2}, \mathrm{CO}, \mathrm{NO}_{\mathrm{y}}, \mathrm{O}_{3}\right.$, toluene, and isoprene) observed at the $\mathrm{T} 0$ and $\mathrm{T} 1$ sites $\left(\mathrm{SO}_{2}\right.$ was not measured at $\left.\mathrm{T} 1\right)$. The plots also show the same observations made on the G-1 aircraft when it flew over or within $2 \mathrm{~km}$ (horizontally) of the $\mathrm{T} 0$ and $\mathrm{T} 1$ sites. Major sources $\mathrm{SO}_{2}$ from oil refineries are located around the Carquinez Strait and in San Francisco Air Basin (total $\mathrm{SO}_{\mathrm{x}}$ emissions were about 14000 tons per year

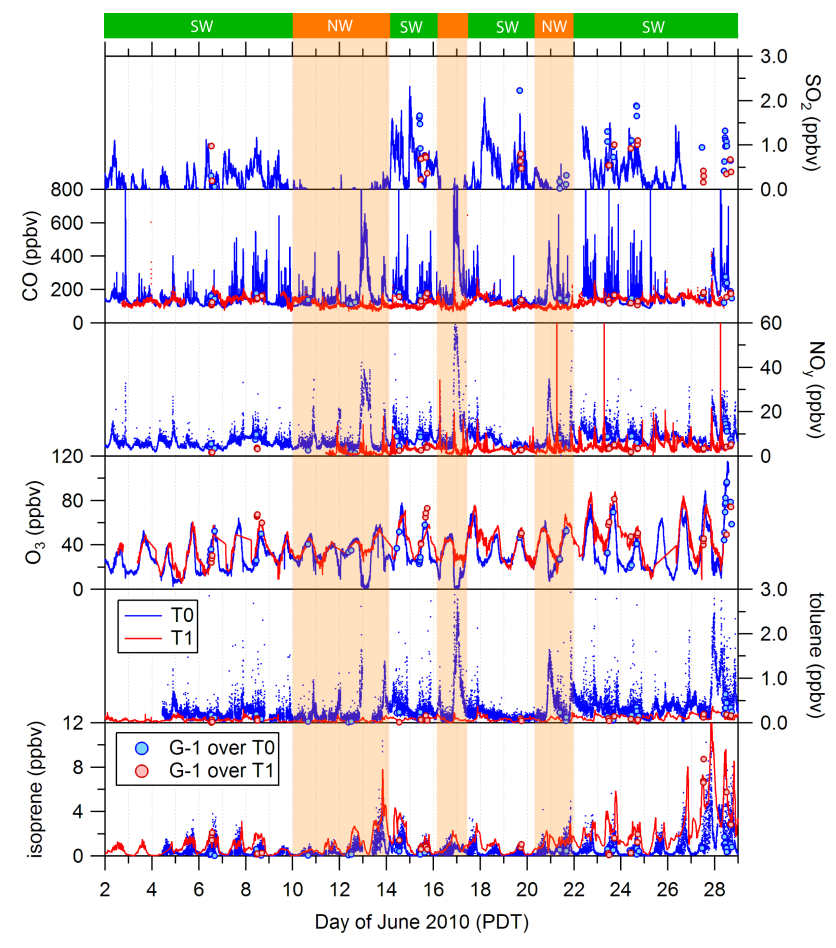

Fig. 6. Comparison of trace gases time series at $\mathrm{T} 0$ and $\mathrm{T} 1$ ground sites along with observations onboard the G-1 during overpasses at the respective sites. The $\mathrm{NO}_{\mathrm{y}}$ instrument at the $\mathrm{T} 1$ site did not operate until 11 June and the $\mathrm{SO}_{2}$ instrument at the T0 site did not operate on 27-28 June.

for 2008). As a result, $\mathrm{SO}_{2}$ was routinely transported to the Sacramento area and into the Central Valley during SW flow and $\mathrm{SO}_{2}$ mixing ratios of 1.5 to $2 \mathrm{ppbv}$ were observed at $\mathrm{T} 0$ during the daytime under these conditions. In contrast, $\mathrm{SO}_{2}$ mixing ratios were nearly zero at the $\mathrm{T} 0$ site at night or during NW flow. $\mathrm{SO}_{2}$ mixing ratios measured onboard the G-1 during overpasses at T0 were typically equal to or up to $50 \%$ higher than those measured at the T0 site. Such differences between ground and airborne observations could be expected as the $\mathrm{SO}_{2}$ plumes were quite narrow with sharp gradients.

As expected, the T0 urban site experienced significantly higher $\mathrm{CO}$ mixing ratios compared to the $\mathrm{T} 1$ site in the rural foothills area. The minimum values at $\mathrm{T} 0$ were generally around $100 \mathrm{ppbv}$ while they were as low as $80 \mathrm{ppbv}$ at the T1 site. The highs at T0 were typically about $400 \mathrm{ppbv}$ around noon, with occasional spikes reaching up to 1000 ppbv, likely due to local vehicular traffic at the site. During the NW flow periods $\mathrm{CO}$ mixing ratios ranging from 400 to $1000 \mathrm{ppbv}$ were observed around midnight, likely due to transport of pollution from Interstate I-80 just 2 miles north of the T0 site. The highs at T1 were typically around $200 \mathrm{ppbv}$, which occurred in the evening after 18:00 PDT when the diluted Sacramento plume was transported to the site under SW winds. $\mathrm{CO}$ mixing ratios measured onboard the G-1 were in 
very good agreement with those measured at the respective ground sites during the overpasses, except when the ground sites experienced spikes due to local emissions. Diurnal behavior of $\mathrm{NO}_{\mathrm{y}}$ mixing ratios at $\mathrm{T0}$ was similar to that of $\mathrm{CO}$, with lows around $3 \mathrm{ppbv}$ and highs ranging between 20 and 40 ppbv. During the NW flow periods, $\mathrm{NO}_{\mathrm{y}}$ mixing ratios ranged between 40 and $80 \mathrm{ppbv}$ at midnight. The G-1 based $\mathrm{NO}_{\mathrm{y}}$ observations were also in good agreement with the ground sites.

The diurnal behavior of $\mathrm{O}_{3}$ mixing ratios at the $\mathrm{T} 0$ and $\mathrm{T} 1$ sites were quite similar despite the marked differences in the precursor trace gas composition and concentrations between the two sites. The highs ranged between 60 and $80 \mathrm{ppbv}$, except for a peak of nearly $120 \mathrm{ppbv}$ on 28 June. The daily $\mathrm{O}_{3}$ peaks at T0 typically occurred around 15:00 PDT while it was often delayed by $\sim 3 \mathrm{~h}$ at $\mathrm{T} 1$ on days when the urban plume was transported to the site during the SW flow periods. The lows were typically around $20 \mathrm{ppbv}$ at night and early morning at both sites throughout the campaign, except during the NW flow periods when $\mathrm{O}_{3}$ mixing ratios at $\mathrm{T} 0$ were nearly zero at midnight due to titration by increased $\mathrm{NO}$ emissions reaching the site. $\mathrm{O}_{3}$ measured aloft during the G1 overpasses were in excellent agreement with the respective ground sites.

The toluene time series is shown here as representative of primary urban VOC emissions. As expected, its diurnal behavior at both sites was similar to that of $\mathrm{CO}$. The highs at $\mathrm{T} 0$ ranged from about 0.5 to $1 \mathrm{ppbv}$ under SW flow and from 1.5 to 3 ppbv during NW flow conditions. In contrast, the diurnal behavior of biogenic isoprene mixing ratios at both the sites followed that of the surface temperatures. The highs ranged between 2 and $12 \mathrm{ppbv}$ around 14:00 PDT while the lows were nearly zero from midnight until dawn. Since the T1 site was located amidst biogenic emissions, isoprene mixing ratios at $\mathrm{T} 1$ were generally about 0.5 to 3 ppbv higher than at T0. Also, since both toluene and isoprene are primary species (emitted at the surface) and chemically reactive, their mixing ratios observed aloft onboard the G-1 were typically about 20 to $50 \%$ lower than at the ground sites during overpasses.

\subsection{Aerosol observations}

\subsubsection{Aerosol composition}

Figure 7 shows comparisons of time series of non-refractory aerosol species concentrations observed with the HR-ToFAMS instruments and black carbon mass observed with SP2 instruments at the $\mathrm{T} 0$ and $\mathrm{T} 1$ sites. The plots also show the same observations made on the G-1 aircraft during overpasses at the ground sites. Non-refractory aerosol composition at both the ground sites and aboard the G-1 was dominated by organics, followed by sulfate, followed by nitrate and ammonium, while chloride was negligibly small (not shown). Organic aerosol (OA) displayed a diurnal cycle that was similar to that of $\mathrm{O}_{3}$ at both sites. Comparisons of the

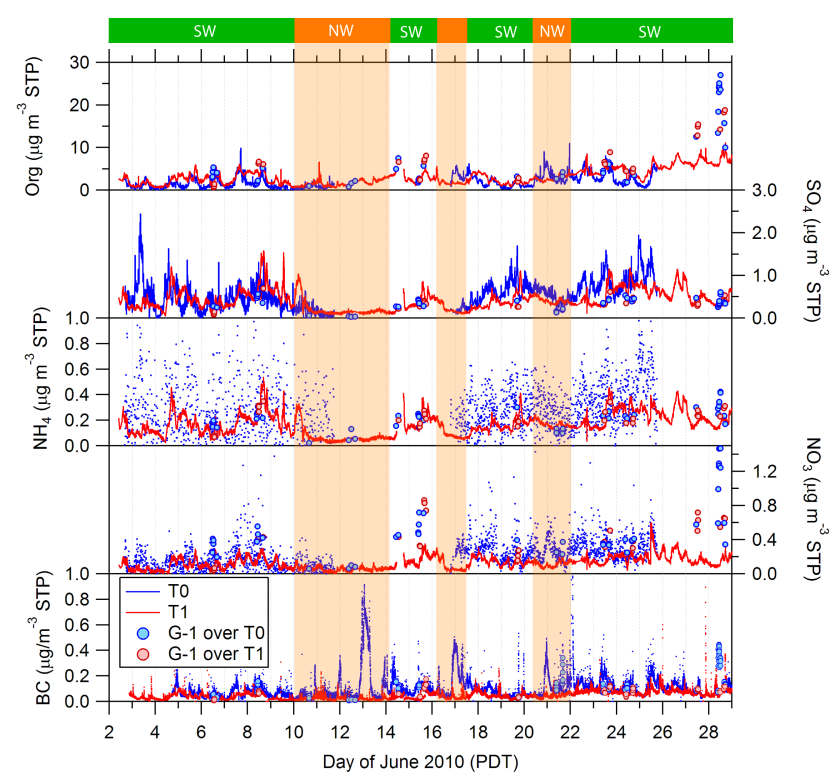

Fig. 7. Comparison of bulk aerosol species time series at T0 and T1 ground sites along with observations onboard the G-1 during overpasses at the respective sites.

estimated and measured aerosol volumes for all three platforms are shown in Fig. S1 (in the Supplement). The estimated volumes were calculated from the AMS species and $\mathrm{BC}$ masses using density of $1.75 \mathrm{~g} \mathrm{~cm}^{-3}$ for sulfate, nitrate, and ammonium, $1.53 \mathrm{~g} \mathrm{~cm}^{-3}$ for chloride, and $1.8 \mathrm{~g} \mathrm{~cm}^{-3}$ for BC. While some day-to-day variations in the agreement between the estimated and measured volumes were observed, especially for the G-1 on 27 and 28 June, the overall agreements were reasonably good with regression fit slopes of 0.91 for T0, 1.0 for T1 and 1.32 for G-1. Further analysis is needed to determine the source of discrepancy in the G-1 data for 27 and 28 June.

The peak OA mass concentrations at the T0 site ranged from 2 to $10 \mu \mathrm{g} \mathrm{m}^{-3}$ STP (i.e., at standard temperature and pressure of $273.15 \mathrm{~K}$ and $1 \mathrm{~atm}$, respectively) around 15:00 PDT when $\mathrm{O}_{3}$ mixing ratio also reached its daily maximum, which is consistent with SOA production from photochemical oxidation of anthropogenic and biogenic VOCs. Minimum OA mass concentrations of less than $0.5 \mu \mathrm{g} \mathrm{m}^{-3}$ STP typically occurred at or after midnight as the wind direction shifted to southeasterly, which brought relatively cleaner background air into the urban area. While the OA mass concentrations remained low during the daytime under NW flow conditions, they were often found to peak around midnight at the $\mathrm{T} 0$ site. $\mathrm{CO}, \mathrm{NO}_{\mathrm{y}}$, toluene, and $\mathrm{BC}$ concentrations also peaked during these events, suggesting that this was primary OA emitted along I-80 (possibly from the road work being performed at night during the campaign period) and brought to the site with NW winds. 
In contrast, $\mathrm{OA}$ mass concentration at the $\mathrm{T} 1$ site peaked at 18:00 PDT or later as the urban plume was transported to the site during the SW flow periods. Note that the peak concentrations at T1 were similar to or slightly higher than those observed at the T0 site even though the urban plume experienced significant dilution as it was transported to the T1 site. During this transit the urban plume mixed with increased biogenic emissions, which could have potentially contributed the additional SOA mass that was observed at T1. Furthermore, the OA mass concentrations at the T1 site often remained high at night and experienced a minimum of $\sim 2 \mu \mathrm{g} \mathrm{m}^{-3} \mathrm{STP}$ in the morning. Preliminary WRF simulation results suggest that the aged $\mathrm{OA}$ accumulating in the foothills area at night were frequently recirculated to the Sacramento urban area within the residual layer the next morning. Evidence of enriched organic aerosol mass in the residual layer is presented at the end of this subsection. As mentioned earlier, the period from 22-28 June experienced a steady buildup of OA, with mass concentrations aloft reaching more than $25 \mu \mathrm{g} \mathrm{m}^{-3} \mathrm{STP}$ at the end, due to more pronounced recirculation of pollutants in the area coupled with possibly more SOA formation from increased biogenic emissions due to warmer temperatures. The OA mass concentrations observed onboard the G-1 were in good agreement with the ground sites values during the overpasses, although they were a factor of 1.5 to 2.5 higher than observed at T1 during the 27 and 28 June flights, likely due to strong spatial gradients of OA in the air in the vicinity of that site on those days.

Sulfate $\left(\mathrm{SO}_{4}\right)$ mass concentrations typically ranged from 0 to $2 \mu \mathrm{g} \mathrm{m}^{-3} \mathrm{STP}$ at both the ground sites, with highs occurring early afternoon and lows around midnight. Ammonium $\left(\mathrm{NH}_{4}\right)$ mass concentrations followed $\mathrm{SO}_{4}$, suggesting it was mostly in the form of ammonium sulfate or bisulfate. In contrast, nitrate $\left(\mathrm{NO}_{3}\right)$ mass concentrations tended to peak later in the afternoon and appeared to follow OA mass. $\mathrm{SO}_{4}$ and $\mathrm{NH}_{4}$ mass concentrations observed onboard the G-1 were in fairly good agreement with the corresponding values at both the ground sites during the overpasses, although the G1 based $\mathrm{SO}_{4}$ concentrations were sometimes found to be up to $50 \%$ lower than the ground sites values. In comparison, $\mathrm{NO}_{3}$ mass concentrations aloft were found to be $50 \%$ higher than the ground sites values during overpasses.

Lastly, as expected, the T0 site experienced significantly higher $\mathrm{BC}$ mass concentrations than the rural $\mathrm{T} 1$ site. The $\mathrm{BC}$ mass concentrations tended to follow the $\mathrm{CO}$ mixing ratios in time. During the SW flow periods, the nighttime minimum values at both the sites were about $0.02 \mu \mathrm{g} \mathrm{m}^{-3}$ STP or lower while the daytime maximum values were up to about $0.3 \mu \mathrm{g} \mathrm{m}^{-3} \mathrm{STP}$. Interestingly, after 22 June, the daily minimum BC mass concentrations ranged between 0.05 and $0.07 \mu \mathrm{g} \mathrm{m}^{-3} \mathrm{STP}$ as there was increased recirculation of aged aerosols and a steady buildup of OA mass concentrations in the region. The pre- and post-June 22 periods thus provide opportunities to examine SOA formation and BC mix- ing state evolution in the same region under significantly different ageing time scales. BC mass concentrations measured onboard the G-1 were in very good agreement with those measured at the respective ground sites during the overpasses. As discussed earlier, during the NW flow periods $\mathrm{BC}$ mass concentrations usually peaked at the T0 site at midnight, with values ranging from 0.5 to $1 \mu \mathrm{g} \mathrm{m}^{-3} \mathrm{STP}$. These events provide opportunities to characterize the size distribution, composition, mixing state, and the associated optical and CCN activation properties of freshly emitted BC and OA particles. It is worth noting here that the SP2-reported $\mathrm{BC}$ mass is dependent on the BC surrogate used to calibrate the incandescent signal from SP2 (Laborde et al., 2012). The SP2 BC mass concentrations reported here for the T0, T1 and G-1 datasets are based on a calibration with Acheson Aquadag. Kondo et al. (2011) suggest that fullerene soot may be a better proxy for urban BC; using a fullerene soot calibration could increase our reported $\mathrm{BC}$ mass concentrations by approximately $67 \%$.

Enhanced concentrations of aged organic aerosols, likely recirculated from the previous day, were often observed in the residual layer (Stull, 1988) during the morning flights over the Sacramento urban area. Figure 8 illustrates such an occurrence during the morning flight on 15 June. The top panel shows a map with the G-1 flight tracks (solid lines) color coded by altitude. The flight started at 08:56 PDT and consisted of several legs crisscrossing over the T0 site at $\sim 360$ and $\sim 660 \mathrm{~mm}$.s.l. altitudes. A spiral up to about $1300 \mathrm{~m}$ m.s.l. was performed at about 09:30 PDT over a location between the T0 and T1 sites. The G-1 then flew back and forth along the foothills from 11:00 PDT to 11:50 PDT, passing over the T1 site three times. The left portion of the bottom panel shows the vertical profile of potential temperature obtained during the spiral. Based on the inflections in this profile, the boundary layer height was estimated at about $590 \mathrm{~mm}$.s.1. and the residual layer height was estimated to extend up to about $950 \mathrm{~m}$ m.s.l., which implies that the G1 legs at $360 \mathrm{~mm}$.s.l. were within the boundary layer while the legs at $660 \mathrm{~mm}$.s.l. were in the residual layer. The right portion of the bottom panel shows the G-1 flight altitude plotted against local time, with the approximate locations of the T0 and T1 sites noted at the bottom of the plot along the time axis. The plot also includes $\mathrm{OA}$ and $\mathrm{NO}_{3}$ mass concentrations and $\mathrm{NO}_{\mathrm{x}} / \mathrm{NO}_{\mathrm{y}}$ ratio along the flight as a function of local time. $\mathrm{NO}_{\mathrm{x}} / \mathrm{NO}_{\mathrm{y}}$ ratios were as high as 0.8 (right over the urban center) within the boundary layer due to fresh emissions of $\mathrm{NO}_{\mathrm{x}}$ in the morning. $\mathrm{NO}_{\mathrm{x}} / \mathrm{NO}_{\mathrm{y}}$ ratios were between 0.2 and 0.3 in the residual layer, which is indicative of aged pollution. Interestingly, OA mass concentrations in the boundary layer were only about $2 \mu \mathrm{g} \mathrm{m}^{-3}$ STP while they were about $6 \mu \mathrm{g} \mathrm{m}^{-3}$ STP in the aged residual layer. Similarly, $\mathrm{NO}_{3}$ concentrations were about $0.5 \mu \mathrm{g} \mathrm{m}^{-3} \mathrm{STP}$ in the boundary layer and about $1.5 \mu \mathrm{g} \mathrm{m}^{-3} \mathrm{STP}$ in the residual layer. 

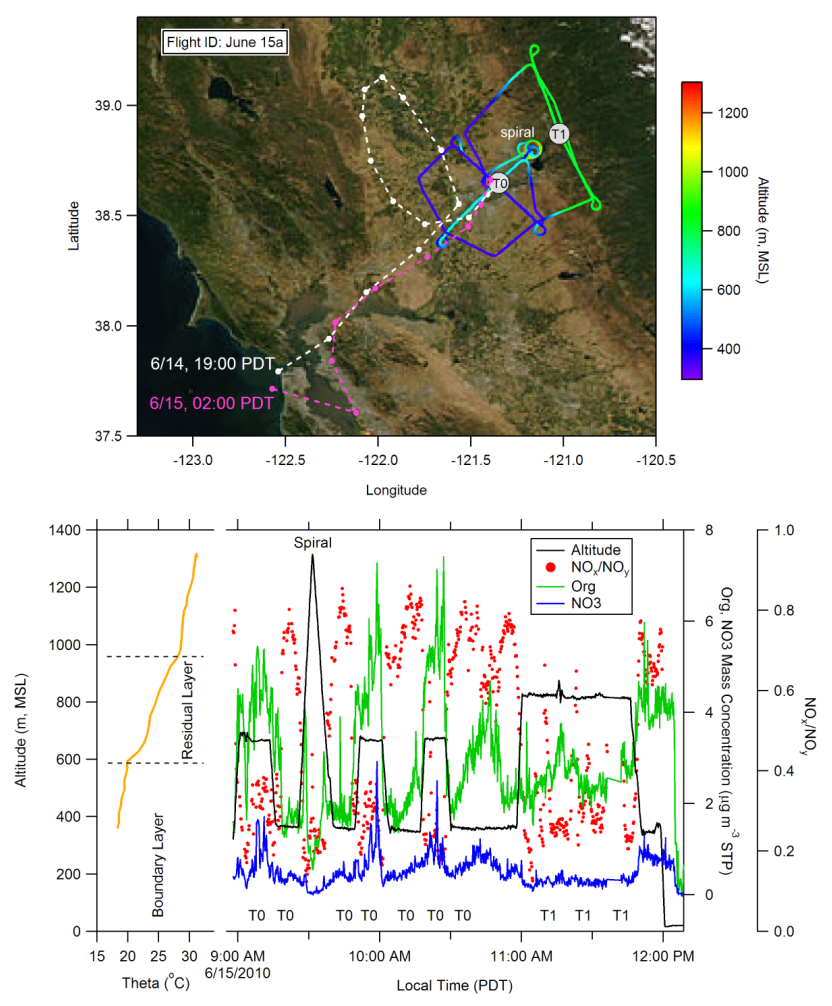

Fig. 8. Example of evidence for aged aerosols (enriched in organic and nitrate) that were often found to be present in the residual layer in the morning. Top: G-1 flight tracks on the morning of 15 June, color coded by flight altitude. The dotted white and pink lines represent forward trajectories of air parcels (see text). Bottom right: vertical profile of potential temperature at the location of the spiral. Bottom left: flight altitude, org and $\mathrm{NO}_{3}$ mass concentrations, and $\mathrm{NO}_{\mathrm{x}} / \mathrm{NO}_{\mathrm{y}}$ ratio plotted along the flight track as a function of local time.

The dotted white and pink lines in the top panel of Fig. 8 represent forward trajectories (computed using WRF forecasts) of air parcels that originated over the ocean (at surface level) off the coast of San Francisco on 14 June at 19:00 PDT and 15 June at 02:00 PDT, respectively, such that both air parcels arrived over the T0 site on June 15 at 10:00 PDT (i.e., during the time period when G-1 was sampling in the area). The filled circles along the trajectories mark the locations of the air parcels at hourly intervals. The air parcel along the pink trajectory was present within the boundary layer and had passed over the Sacramento downtown area at about 08:00 PDT before reaching T0 at 10:00 PDT. In contrast, the air parcel along the white trajectory was present in the residual layer, and it had undergone a recirculation in the Sacramento Valley at night before arriving over the T0 site at 10:00 PDT. These results are consistent with the aerosol composition and $\mathrm{NO}_{\mathrm{x}} / \mathrm{NO}_{\mathrm{y}}$ ratio observed in the boundary and residual layers as discussed above. Detailed analyses of the chemical composition of the aerosols in the boundary and residual layers will be conducted, and the potential contri- butions of the Bay Area and Sacramento emissions and the ensuing daytime as well as nighttime chemistry in the formation of these aerosols will be examined in subsequent studies.

\subsubsection{Aerosol number concentration and size distribution}

Figure 9 shows time series of aerosol number concentrations above $10 \mathrm{~nm}$ diameter (denoted as $N_{>10}$ ) measured by the CPC-3010 instruments at the T0 and T1 sites along with the CPC-3010 observations onboard the G-1 during the overpasses above these sites. These number concentrations are put in context with the time series of $\mathrm{SO}_{2}$ mixing ratio at the T0 site along with the G- 1 overpasses at T0. During SW flow periods, the T0 site experienced significant increases in aerosol number concentrations from the nighttime lows of $\sim 5000 \mathrm{~cm}^{-3}$ to about $35000 \mathrm{~cm}^{-3}$ (maximum of $45000 \mathrm{~cm}^{-3}$ ) between 08:00 and 13:00 PDT. These rapid increases in number concentrations coincided with increases in $\mathrm{SO}_{2}$ mixing ratios from below detection limit at night to about 1-2 ppbv, suggesting that these particles were either nucleated at the $\mathrm{T} 0$ site via $\mathrm{H}_{2} \mathrm{SO}_{4}$ formation from $\mathrm{SO}_{2}$ photooxidation, followed by growth to $10 \mathrm{~nm}$ and larger sizes, or they were transported to the T0 site shortly after nucleating elsewhere, with continued growth during transit. The increases in the number concentrations at the $\mathrm{T} 1$ site occurred almost simultaneously with the T0 site or were sometimes delayed by $1-3 \mathrm{~h}$, and the daily maximum values reached up to $20000 \mathrm{~cm}^{-3}$ (i.e., about a factor of 2 lower than at T0). Unfortunately, $\mathrm{SO}_{2}$ was not measured at the $\mathrm{T} 1$ site, so a similar comparison could not be made. As the $\mathrm{SO}_{2}$ mixing ratios were small and mostly below detection limit during the NW flow periods, the daytime increases in $N_{>10}$ values were also significantly reduced at both the sites, with highs reaching less than 20000 and $10000 \mathrm{~cm}^{-3}$ at T0 and T1, respectively. The daily increases in $N_{>10}$ values at T0 and T1 were also greatly reduced during the period from 25-28 June despite the high $\mathrm{SO}_{2}$ mixing ratios observed aboard the G1 during overpasses. This reduction in $N_{>10}$ was likely due to the steady buildup of aged aerosols of larger sizes, which effectively suppressed new particle formation and survival of newly formed particles by providing large pre-existing surface area for $\mathrm{H}_{2} \mathrm{SO}_{4}$ condensation and coagulation. The CPC-3010 number concentrations observed aboard the G1 were in excellent agreement with those measured at both ground sites during the overpasses through the entire campaign.

The G-1 also carried a CPC-3025 which measured the total number concentrations of particles larger than $3 \mathrm{~nm}$, denoted as $N_{>3}$. Figure 10a shows a scatter plot of all the CPC-3025 versus CPC-3010 number concentrations observed aboard the G-1, with points colored by $\mathrm{SO}_{2}$ mixing ratio that was also observed aboard the G-1. Note that values of both $N_{>3}$ and $N_{>10}$ were generally found to increase with increasing $\mathrm{SO}_{2}$ mixing ratios, and while the $N_{>3} / N_{>10}$ ratios reached 


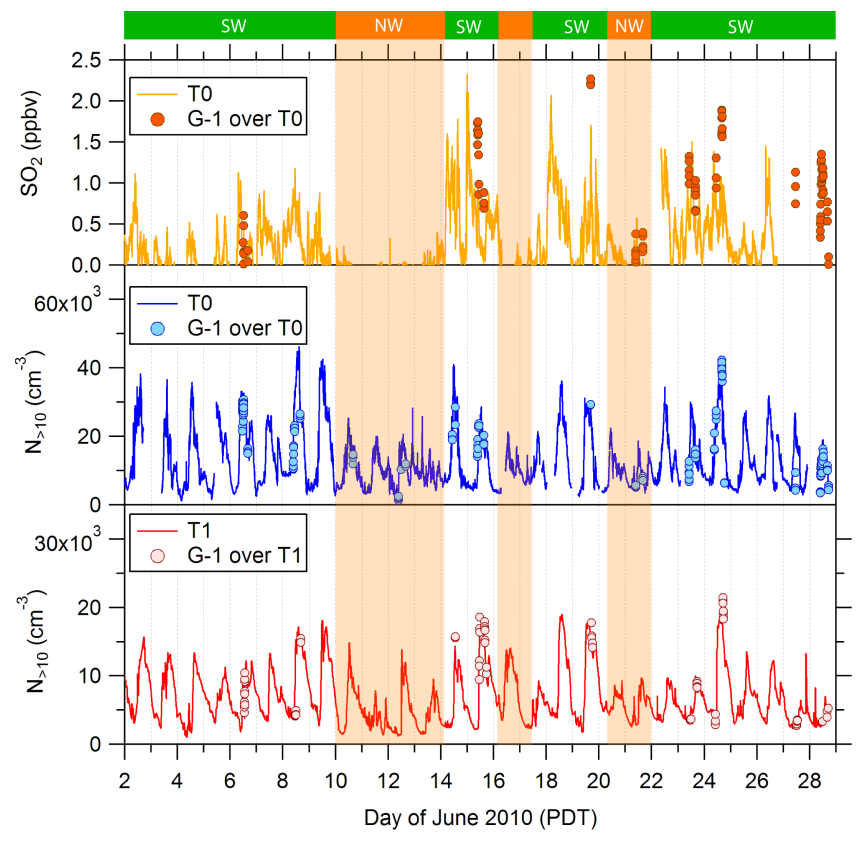

Fig. 9. Time series of $\mathrm{SO}_{2}$ mixing ratio at $\mathrm{T} 0$ site and comparison of CPC 3010 number concentration $\left(N_{>10}\right)$ time series at T0 and $\mathrm{T} 1$ sites along with observations onboard the G-1 during overpasses at the respective sites.

as high as 4 , the high values generally did not coincide with enhanced $\mathrm{SO}_{2}$ mixing ratios, with some of the highest ratios corresponding to the lowest $\mathrm{SO}_{2}$ mixing ratios. This result is reasonable if the increased sulfate formation (and SOA) caused the large number of newly formed particles to more rapidly grow larger than $10 \mathrm{~nm}$. Figure $10 \mathrm{~b}$ shows the same scatter plot, with points colored by isoprene mixing ratio observed aboard the G-1. Points with isoprene mixing ratios less than $1 \mathrm{ppbv}$ were removed from the plot for clarity. Note that the highest $N_{>3} / N_{>10}$ ratios corresponded to the highest isoprene mixing ratios (and the lowest $\mathrm{SO}_{2}$ mixing ratios), suggesting that biogenic species may have played an important role (in the absence of appreciable amounts of $\mathrm{SO}_{2}$ ) in new particle formation and their initial growth to detectable sizes.

Figure 11 shows the time series of aerosol number size distributions at the T0 and T1 sites. The plot for each site consists of size distribution data from the Scanning Mobility Particle Sizer (SMPS) and Aerosol Particle Sizer (APS) instruments. The SMPS measures particle mobility diameter $\left(D_{\mathrm{m}}\right)$ ranging from 0.01 to $\sim 0.7 \mu \mathrm{m}$ while the APS measures particle aerodynamic diameter $\left(D_{\mathrm{a}}\right)$ ranging from 0.5 to $20 \mu \mathrm{m}$. Note that the size distribution data from both the instruments are plotted using the same color scheme but with instrumentspecific color scales that differ by three orders of magnitudes. Comparison of the number size distributions measured by the SMPS and APS in the overlap region is illustrated in Fig. S2. Aerodynamic diameter from APS was converted to geomet-
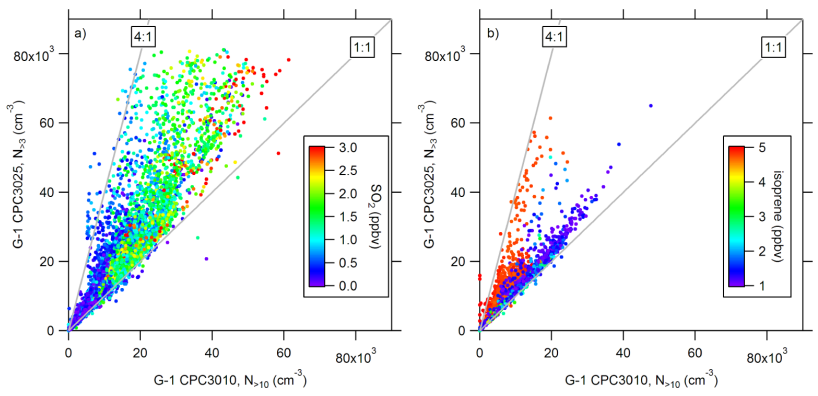

Fig. 10. Scatter plots of CPC-3025 vs. CPC-3010 number concentrations observed on the G-1: (a) the points are colored by the corresponding $\mathrm{SO}_{2}$ mixing ratios; (b) the points are colored by the corresponding isoprene mixing ratios (points with isoprene mixing ratios $<1 \mathrm{ppbv}$ were removed from the plot for clarity). Grey lines show slopes of $4: 1$ and $1: 1$.

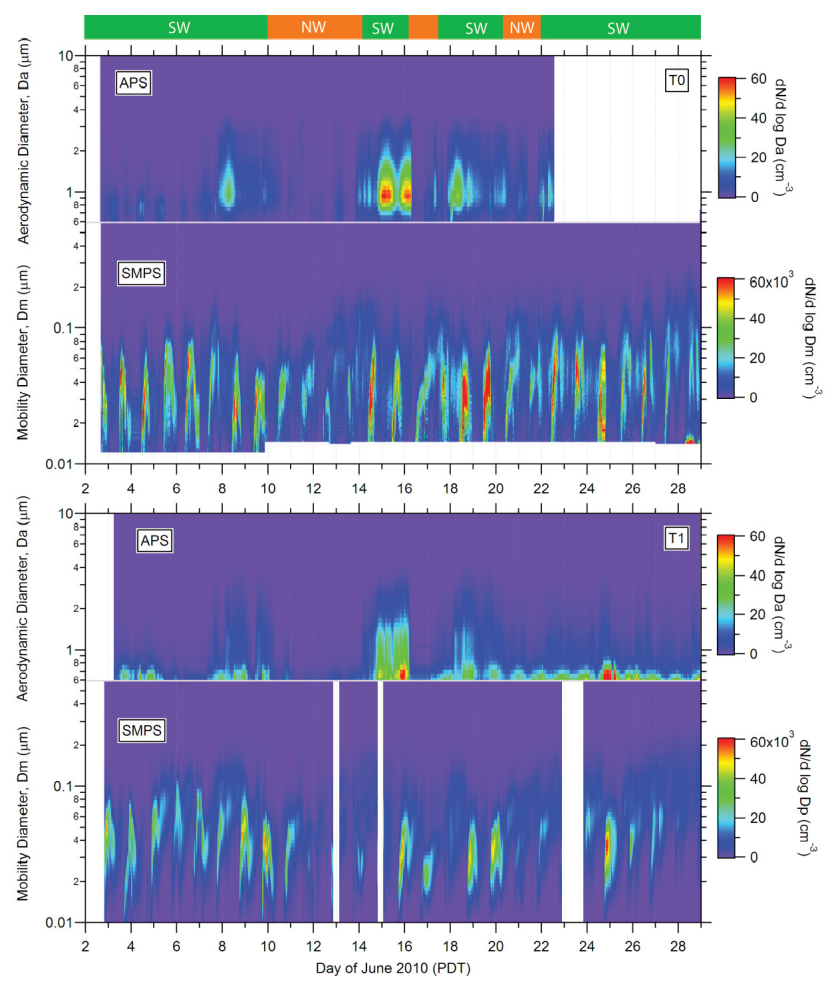

Fig. 11. Comparison of aerosol number size distributions at T0 and T1 sites. Note that the color scales for APS and SMPS distributions differ by three orders of magnitude.

ric diameter by assuming a density of $2.25 \mathrm{~g} \mathrm{~cm}^{-3}$ for coarse mode particles, which were found to be sea salt aerosols as discussed below. Number concentrations from the two instruments appear to agree very well around $0.56 \mu \mathrm{m}$ geometric diameter.

The APS data at both ground sites show the appearance of coarse mode particles on several days (e.g., 8, 14, 15, 18 June) when the wind direction was predominantly southwesterly. As discussed in the previous section and shown in Fig. 8 
for 15 June, WRF tracer forecast simulations for these periods indicated appreciable transport of air from the Pacific Ocean into Sacramento through the Carquinez Strait, suggesting that the coarse particles were composed of sea salt, with some dust particles mixed into the air mass along the way. Indeed, the single particle mass spectrometer data (discussed in the next subsection) support this hypothesis. The coarse particles were mostly absent during the NW flow periods.

Consistent with the $N_{>10}$ time series shown previously in Fig. 9, the SMPS data at both ground sites show the appearance of $\sim 10 \mathrm{~nm}$ diameter particles in large concentrations between 08:00 to 10:00 PDT. These particles were then found to rapidly grow until mid-afternoon, with the particle composition data indicating this was largely due to condensation of secondary organics and to a lesser extent due to condensation of sulfuric acid, nitric acid, and ammonia as shown previously in Fig. 7. More detailed analysis of carefully selected aerosol growth events should provide valuable information for constraining aerosol chemistry and microphysics models to evaluate and test SOA formation and $\mathrm{BC}$ ageing mechanisms under different conditions. Such studies will be the subject of subsequent papers.

\subsubsection{Aerosol mixing state from SP-MS instruments}

A state-of-the-art single particle mass spectrometer (SP-MS) instrument was deployed at each site and on the G-1 to obtain a more complete picture of the different particle types and evolution of aerosol mixing states. SPLAT II was located at the T0 site to continuously measure the size, composition, and density of individual particles with diameters between 50 to $2000 \mathrm{~nm}$. Each day, SPLAT II characterized the size of $\sim 7$ million and composition of $\sim 350000$ particles. It also measured the aerosol size distribution and number concentrations of particles with diameters larger than $85 \mathrm{~nm}$ (Vaden et al., $2011 b, c)$. Simultaneous measurements of individual particle size, density and composition were conducted for 121000 individual particles. These measurements were performed 2-3 times per day. In addition, SPLAT II was used to conduct the first measurements of the kinetics of evaporation, phase, and morphology for size-selected ambient SOA particles at ambient temperature (Vaden et al., 2011a).

PALMS was located at the T1 site to sample the relatively aged urban aerosols. PALMS measured the same quantities as SPLAT II (i.e., particle size, composition, and density) on a single particle basis. PALMS is not an automated instrument and therefore could not be run unattended. Data were nonetheless acquired on most field days, with a particular emphasis on acquisition during aircraft flights and afternoon periods when the Sacramento plume had transited to the T1 site. PALMS detected individual particles from $\sim 125$ to $3000 \mathrm{~nm}$, although it is noteworthy that transmission rate rapidly dropped at sizes lower than $\sim 200 \mathrm{~nm}$ and greater than $\sim 2000 \mathrm{~nm}$. In total $\sim 100000$ particles were analyzed.
Particular emphasis was placed on collecting PALMS data simultaneously with $f(\mathrm{RH})$ measurements to determine the effect of chemical composition on particle hygroscopicity. An $\mathrm{f}(\mathrm{RH})$ measurement was also made at the T0 site during the second half of the campaign.

An A-ATOFMS was flown on the G-1 to measure the sizeresolved mixing state of individual particles with diameters ranging from 70 to $1200 \mathrm{~nm}$. Dual polarity mass spectra were acquired which allows for the identification of the source and the extent of atmospheric processing of the particles. Over all flights, $\sim 60000$ particles were analyzed. Due to particle transmission efficiencies, most particles that were sampled ranged from 100 to $1000 \mathrm{~nm}$ diameters, with a mode centered at $\sim 360 \mathrm{~nm}$ during most flights. These airborne measurements will be particularly useful in understanding how the mixing state of different types of particles evolved in the Sacramento urban plume as it was advected downwind.

Analysis of individual particle mass spectra at all locations indicates that at any given time there were always a number of different types of particles with different compositions and size distributions present. Figure 12 shows the average fraction of particles observed by A-ATOFMS for each G-1 flight and 12-min averaged fraction of particles observed by PALMS at the T1 site classified into specific particle types. The vast majority of aerosol particles characterized during the study were composed of oxygenated organics mixed with various amounts of sulfates: from sulfate-dominated particles to those containing mostly organic species. In addition, fresh and processed soot particles, biomass burning aerosol, amines, sea salt (both fresh and processed), and a small number of mineral dust and other inorganic particles were present. The relatively larger number fraction of sea salt particles observed aloft by the G-1 and at both ground sites on 8 and 15 June is consistent with the APS size distribution data shown previously in Fig. 11.

SPLAT II data for 6 June are shown in Fig. 13 to illustrate a more detailed view of the evolution of relative fractions of different particle types in a single day. Early in the morning aerosol mass loadings and number concentrations were low and most particles were composed of organics mixed with a significant fraction of sulfate. Larger particles containing a higher fraction of sulfate were evident from the size-dependence of particle density. An example of sizedependent particle density data measured by SPLAT II is illustrated in Fig. 14. In general, density tended to increase with particle size. For example, during the morning of 6 June, $80 \mathrm{~nm}$ particles had a density of $\sim 1.3 \mathrm{~g} \mathrm{~cm}^{-3}$ while the density of $200 \mathrm{~nm}$ particles was $\sim 1.6 \mathrm{~g} \mathrm{~cm}^{-3}$.

By around 09:00 PDT, the number concentrations of particles smaller than $14 \mathrm{~nm}$ (measured by SMPS) began to increase, which indicated the growth of newly formed particles by SOA condensation. As the day progressed and the emitted VOCs were oxidized, SOA-containing particles increased in size, making it possible to characterize their size, composition, and density with SPLAT II. By early afternoon 

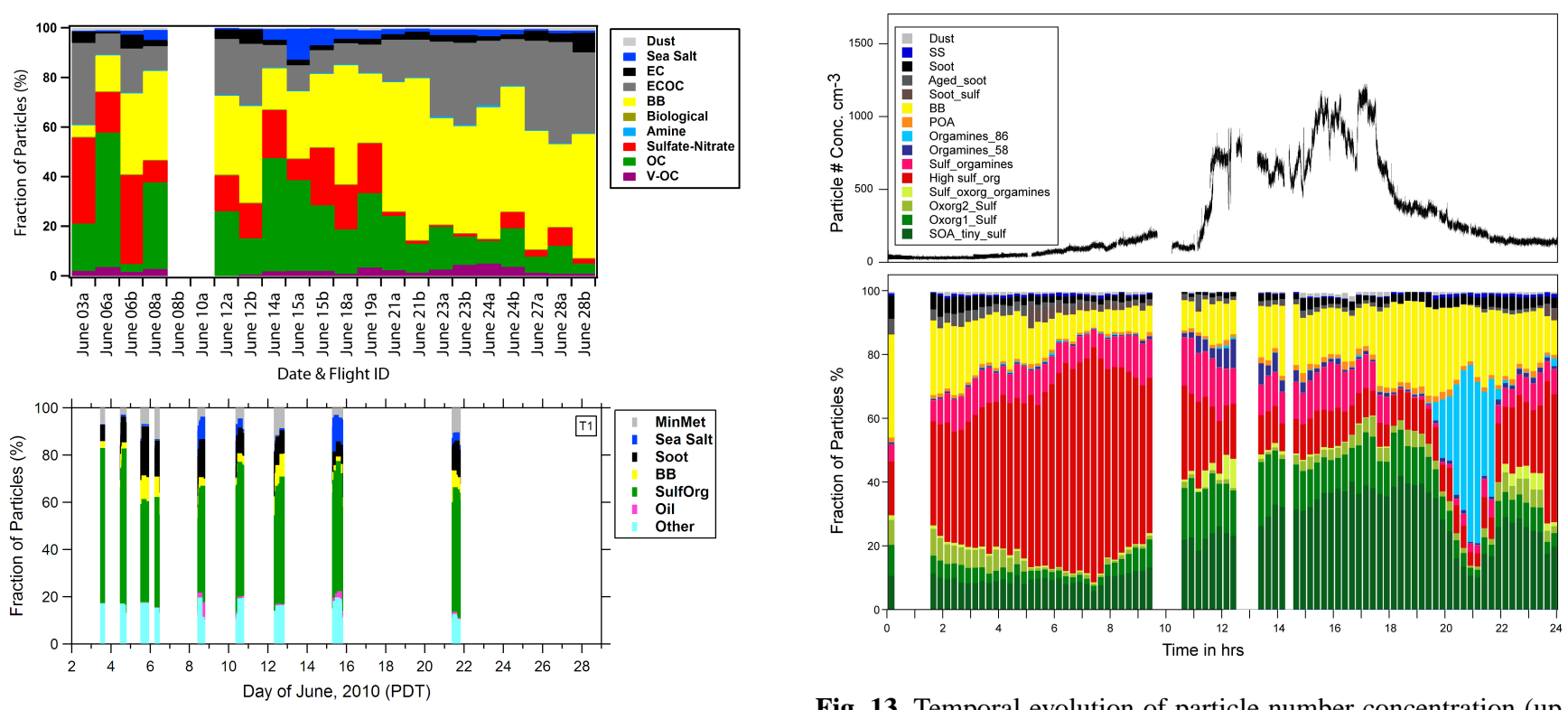

Fig. 12. Variations in fractions of different particles observed by ATOFMS aboard the G-1 (upper panel) and by PALMS at the T1 site (lower panel). EC is elemental carbon, BB is biomass burning particles, $\mathrm{V}-\mathrm{OC}$ is organic particles containing vanadium, MinMet is mineral dust and metallic particles.

aerosol composition was dominated by oxygenated organics mixed with small amount of amines and sulfate $(\sim 10 \%$ volume fraction), and the density of $80 \mathrm{~nm}$ to $150 \mathrm{~nm}$ particles was $\sim 1.3 \mathrm{~g} \mathrm{~cm}^{-3}$. These SOA-dominated particles were then used to study evaporation kinetics at room temperature (Vaden et al., 2011a). The results of this study show that evaporation of these size- and composition selected ambient organic particles was extremely slow and size-independent, suggesting that the particles were in a quasi-solid state.

While the single particle data described above provide valuable information, they are particularly useful when used in combination with other instruments. Three examples are noteworthy and are listed among the analyses envisioned in the next subsection. First, BC concentration, size and coating state can be obtained by the SP2 instrument which was deployed at both ground sites and aboard the G-1 during CARES. The SP-MS data complement the SP2 data by providing a qualitative measure of the chemical composition of the coating material internally mixed with the BC. Second, biomass burning aerosol was episodically present during CARES, particularly during the warmer and drier period later in the field study. Gas-phase acetonitrile can be used as a tracer to detect the presence of biomass burning aerosol and the resulting perturbations to SOA when biomass burning aerosol was present can be investigated. Finally, SP-MS data can be used to determine periods of particular interest for off-line analyses of collected and archived TRAC, DRUM, and SEM samples to further probe the chemical composition, mixing state, and morphology of particles.

Fig. 13. Temporal evolution of particle number concentration (upper panel) and the corresponding fraction of particles with different compositions (lover panel) as observed by SPLAT II on 6 June at the T0 site. SS is sea salt, BB is biomass burning particles.

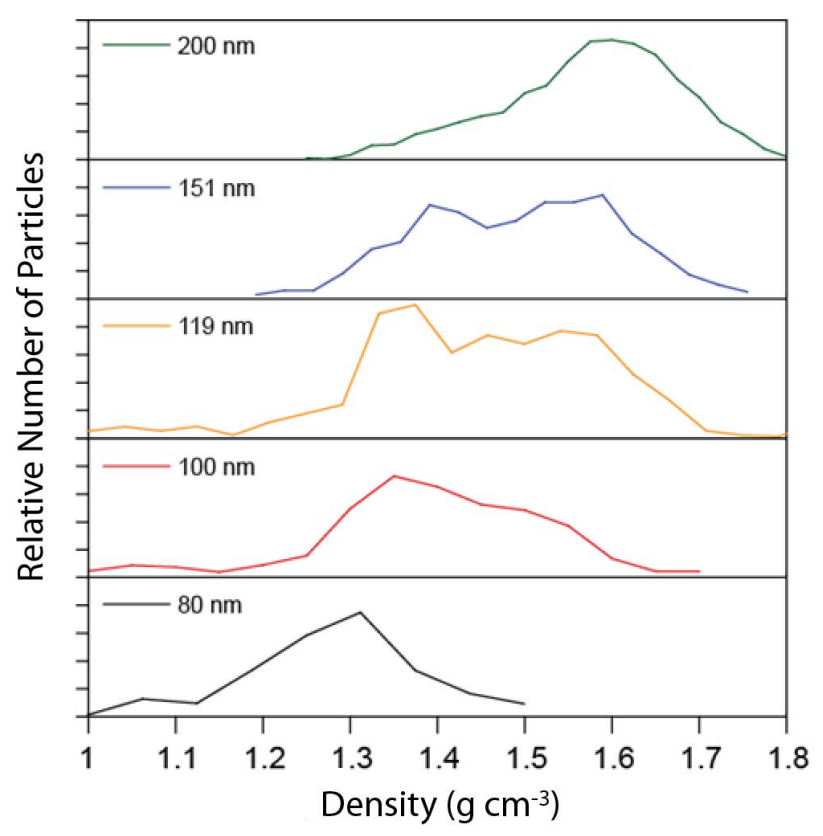

Fig. 14. Size-dependent particle densities as measured by SPLAT II on 6 June at 10:00 PDT.

\subsubsection{BC mixing state from SP2 instruments}

The single particle soot photometer (SP2) measures BC via laser-induced incandescence and can obtain some useful information about particle size, relative coating thickness and mixing-state based on the scattering signal from the both $\mathrm{BC}$ and non-BC containing particles (Stephens et al., 2003; 
Schwarz et al., 2006; Subramanian et al., 2010). The heart of the SP2 is the laser-induced (1064 nm, Nd:YAG) incandescence signal from BC. Incorporation of narrowband and broadband filters enables the SP2 to be highly selective towards BC. The incandescence intensity is linearly proportional to the BC: more mass leads to stronger incandescence. In addition to providing data on the $\mathrm{BC}$ number density and mass concentration, since the SP2 is inherently a particle-byparticle instrument, individual incandescence signals can be collected and binned to provide a mass equivalent diameter (MED) size distribution ( $\left.\mathrm{d} N_{\mathrm{BC}} / \mathrm{dLog} D_{\mathrm{MED}}\right)$ and mass distribution, $\left(\mathrm{d} M_{\mathrm{BC}} / \mathrm{dLog} D_{\mathrm{MED}}\right)$. The nominal BC mass detection range for the SP2 units deployed at CARES was from $\sim 0.2$ fg particle ${ }^{-1}$ to $\sim 250 \mathrm{fg}_{\text {particle }}{ }^{-1}-60 \mathrm{~nm}$ to $650 \mathrm{~nm}$ MED, for an assumed particle density of $1.9 \mathrm{~g} \mathrm{~cm}^{-3}$.

The SP2 is also outfitted with a scattering channel that, when combined with the incandescence signal, allows the BC mixing-state to be probed (Moteki and Kondo, 2008; Subramanian et al., 2010). The cornerstone of this technique is that a fully coated $\mathrm{BC}$ particle must first boil-off its coating before the $\mathrm{BC}$ will incandesce. The time necessary to vaporize this coating is referred to as the lagtime $(\Delta \tau)$, which is the temporal lag of the incandescence signal relative to the scattering signal - the larger the lagtime the thicker the coating, although the relationship between these two quantities is complex. By plotting the observed lagtimes versus the $\mathrm{BC}$ MED, a semi-quantitative picture of the $\mathrm{BC}$ mixing-state can be rendered enabling the evolution of the mixing-state to be directly probed. As advocated by Moteki and Kondo (2008) and more recently by Subramanian et al. (2010), due to instrument limitations, a demarcation between "thinly" coated (nascent) BC and "thickly" coated BC is strongly encouraged when using the lagtime analysis. For the current study, this dividing line between thinly and thickly coated BC particles is $1.25 \mu \mathrm{s}$; that is, $\Delta \tau>1.25 \mu \mathrm{s}$ indicates the presence of thickly coated BC particles while shorter lagtimes designate the presence of thinly coated $\mathrm{BC}$ particles. In addition to the lagtime analysis, the complementary analysis technique of estimating the coating thickness through examination of the difference between calculated $\mathrm{BC}$ core mass equivalent diameter and an estimate of the coated BC particle diameter determined from the scattering signal amplitude, was also conducted (Gao et al., 2007; Moteki and Kondo, 2006).

An example of the incandescence-scattering lagtime analysis as a function of $\mathrm{BC}$ mass equivalent diameter is shown in Fig. 15 for the 28 June morning and afternoon flights. Contours are normalized number concentrations in an effort to highlight the differences between the two flights (red $=0.9 /$ blue $=0.2$ ). Using the linear relationship between lagtime and coating thickness shown by Subramanian et al. (2010), the right axis is the estimated coating thickness outlined above. It is important to note that an SP2-based analysis of the $\mathrm{BC}$ mixing state requires usable signals from both the scattering and incandescence channels. Despite the fact that the incandescence signal can probe $\mathrm{BC}$ mass equiva-
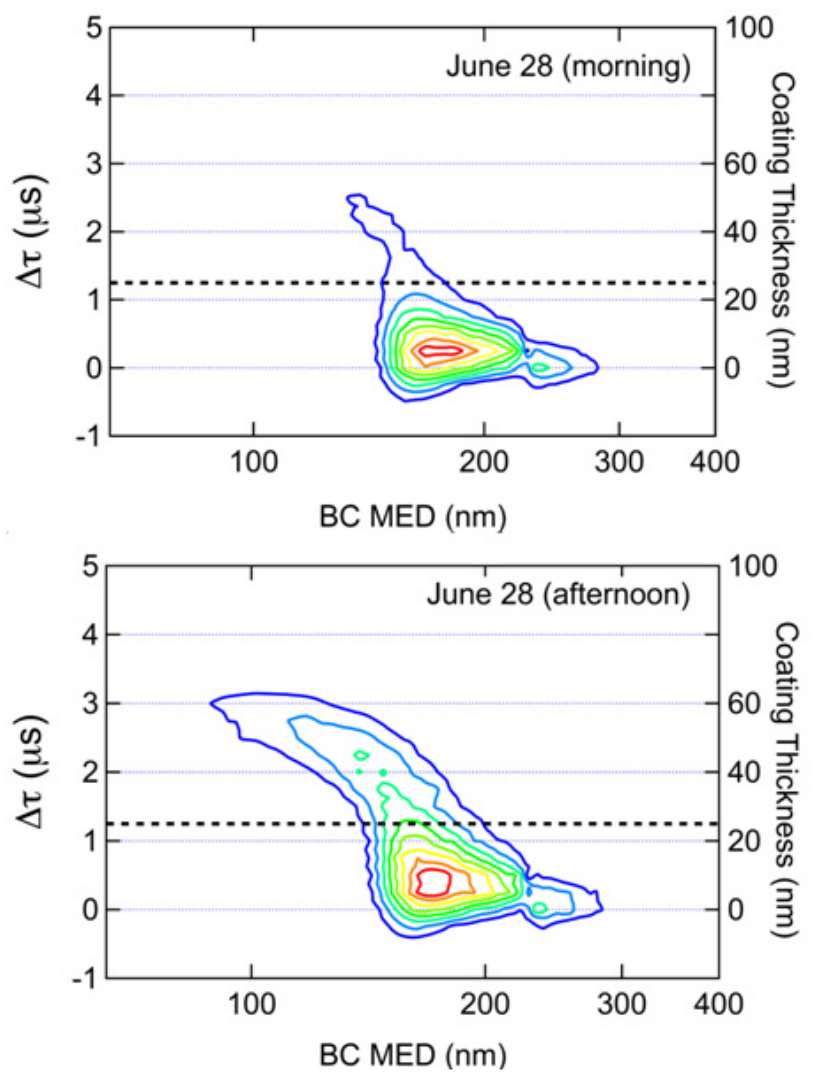

Fig. 15. The time delay between the observance of the incandescence signal peak relative to the peak in the scattering signal (incandescence-scattering lagtime, $\Delta \tau$ ) is plotted as a function of the BC mass equivalent diameter (MED) for the morning and afternoon flights conducted on 28 June. Number concentration contours are normalized to unity (red $=0.9$, blue $=0.2$ ) to highlight the differences between the two flights. Since the non-refractory coating must be burned off before the $\mathrm{BC}$ core will incandesce, the recorded lagtime can serve as a proxy for coating thickness - the larger the lagtime, the greater the coating thickness. The morning ensemble lagtimes are dominated by thinly coated soot whereas in the afternoon an increase in the fraction of thickly coated larger diameter $\mathrm{BC}$ core is observed.

lent diameter ranging from nominally $60-600 \mathrm{~nm}$, the limited range of the scattering channel ( $\sim 175 \mathrm{~nm}$ to $350 \mathrm{~nm}$ ) limits this analysis to only those coated $\mathrm{BC}$ particles that fall into the latter range. Examination of the morning flight lagtime data (top trace in Fig. 15) reveals that the observed distribution is dominated by thinly coated BC particles while the 28 June afternoon flight reveals an increase in the number of thickly coated BC cores, consistent with BC ageing. Preliminary analysis of the $\mathrm{BC}$ mass distributions for the two flights reveal that the mean mass diameter (MMD) increases from $137( \pm 1.2)$ with a geometric standard deviation (GSD) of $1.4( \pm 0.03)$ for the morning flight to $142( \pm 1.1) \mathrm{nm}$ with a (GSD) of $1.4( \pm 0.03)$, where the error is $1-\sigma$. Whether this MMD shift (or alternatively, loss of smaller diameter, thickly 
coated $\mathrm{BC}$ particles) is due to instrument limitation(s) or advection will be the subject of the ensuing analysis on this G-1 dataset. Additional lines of analysis will include better quantification of the $\mathrm{BC}$ mixing-state (coating thickness) by correcting the estimated coating thicknesses for host material loss due to heat transfer from the light absorbing core (Gao et al., 2007; Moteki and Kondo, 2006) and estimating the ratio of the coating mass/BC mass as well as examining the light absorbing properties in the core-shell limit. Towards this end, preliminary analysis indicates an increase in the coating mass to $\mathrm{BC}$ ratio between the morning and afternoon flights.

\subsubsection{Offline analyses of particle samples}

Comprehensive analyses of particle samples collected at T0 and T1 ground sites and onboard the G-1 can be performed using an array of modern, state-of-the-art analytical techniques available at two DOE scientific user facilities (Environmental Molecular Sciences Laboratory at Pacific Northwest National Laboratory and Advanced Light Source at Lawrence Berkeley National Laboratory) and at Michigan Technological University (Applied Chemical and Morphological Analysis Laboratory). The primary techniques for analysis are Computer Controlled Scanning Electron Microscopy with Energy Dispersed analysis of X-rays (CCSEM/EDX) (Li et al., 2003; Laskin et al., 2006) and Scanning Transmission X-ray Microscopy with Near Edge X-ray Absorption Fine Structure spectroscopy (STXM/NEXAFS) (Moffet et al., 2010b). These techniques provide information on particle morphology, elemental composition, mixing states, and partitioning of oxidation states, which yield deeper insights into atmospheric ageing of different types of aerosols. Although particle samples were collected continuously at the ground sites and on many G-1 flights, only a small subset will be chosen for detailed analysis. The periods of interest are chosen based on observations from other collocated instruments and meteorological considerations.

Figure 16 shows examples of SEM images of aerosol particles collected at the T0 site. The low magnification image (a) includes (i) a large dust particle, (ii) relatively small spherical particles, (iii) fractal-like soot particles, and (iv) an irregularly shaped particle. Image (b) shows a close-up view of a fractal-like BC particle with an open structure (i) without substantial coating and (ii) with coating. Since SEM imaging is operated under vacuum, volatile aerosol components typically evaporate from the filter. An example of an evaporated liquid particle is visible in the lower right corner of image (b). Image (c) shows a compacted, internally mixed BC particle, and image (d) shows a particle with BC inclusion. These micrographs highlight the morphological complexities of freshly emitted and aged BC particles as well as of the underlying ageing mechanisms that produce the variation in coating thickness. From these images it is also evident that coated and compacted internally mixed BC monomers are larger in size and have higher polydispersity

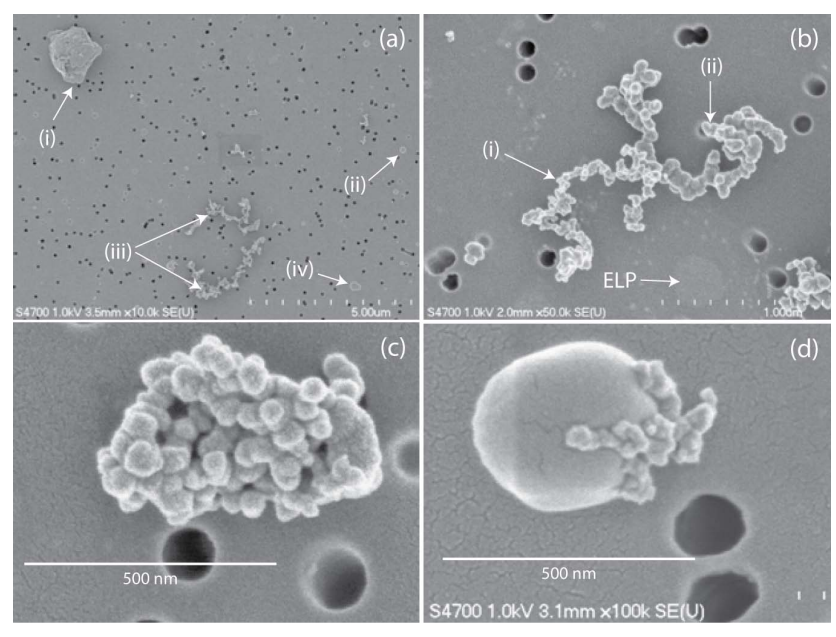

Fig. 16. FE-SEM images of aerosol particles collected at the T0 site: (a) a low magnification image showing (i) dust particle, (ii) spherical particle, (iii) fractal-like particles, (iv) irregularly-shaped particle; (b) fractal-like particle with open structure, (i) soot without evident coating, (ii) soot with relatively thick coating, ELP - evaporated liquid particle; (c) compacted BC particle internally mixed; (d) particle with $\mathrm{BC}$ inclusion. The dark dots are the pores in the filter.

than monomer distributions in nascent BC. For example, the geometric mean diameter for thickly coated $\mathrm{BC}$ is $68 \mathrm{~nm}$ with a standard deviation of $10 \mathrm{~nm}$ (Fig. 16b-(ii)), whereas for compacted internally mixed soot the geometric mean diameter of the monomers is $42.1 \mathrm{~nm}$ and the standard deviation is $10.2 \mathrm{~nm}$ (Fig. 16c), versus a geometric mean diameter of $39.8 \mathrm{~nm}$ and a standard deviation of $5.6 \mathrm{~nm}$ for nascent soot (Fig. 16b-(i)). The polydispersity in various mixing states affects the fractal and optical properties of soot. Future studies will focus on the analysis of the aerosol mixing state and association with optical properties, the diurnal variation of fractal properties of soot, the relation between particle morphology type and optical properties, and the elemental composition of single particles using EDX analysis.

In addition to information on carbonaceous particle ageing, composition, organic coatings, and size resolved mixing state, spectromicroscopy studies can also provide information on sulfur bonding (Hopkins et al., 2008), organic coatings on sea salt (Pratt et al., 2010), and Fe oxidation states (Moffet et al., 2012). Figure 17 shows characteristic SEM images and STXM/NEXAFS chemical maps for particles collected during the photochemical aerosol buildup period at the end of the field campaign (27-29 June). Particles sampled on the morning of 27 June at T0 were primarily composed of inorganic cores surrounded by varying amounts of organics, whereas particles sampled at $\mathrm{T} 1$ on the afternoon of 28 June were primarily composed of a homogenous inorganic/organic mixed phase. This evidence of photochemical aging is analogous to observations in Mexico City during the MILAGRO campaign (Moffet et al., 2010c). 

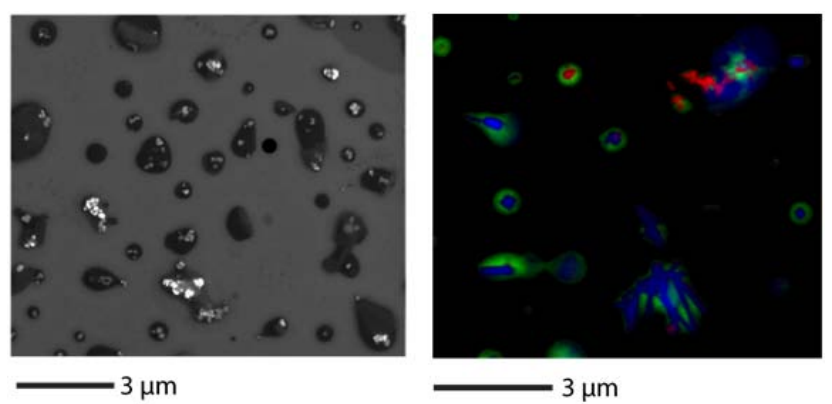

Fig. 17. SEM (left panel) and STXM (right panel) images showing internal heterogeneity of particles collected in CARES study. STXM maps derived by singular value decomposition depict organic dominant phase (green), inorganic dominant phase (blue) and elemental carbon (red). Images are not from the same sample region.

CCSEM/EDX and STXM/NEXAFS analyses of TRACcollected particles onboard the G-1 on 15 June (a strong SW flow event) showed the presence of sea salt particles over Sacramento. Forward trajectories simulated by WRF (Fast et al., 2012) coupled with Lagrangian particle dispersion model (Doran et al., 2008) analysis confirmed that the sea salt particles were transported from the Pacific Ocean/Bay Area. Interestingly, these particles were found to be internally mixed with organics, which were likely SOA species formed in these particles during the transit from the Bay Area. Surprisingly, these particles had experienced substantial chloride depletion that could not be explained by the known reactivity of sea salt with nitric and sulfuric acids. This study, recently published by Laskin et al. (2012), is the first field evidence that SOA, consisting of weak organic acids, may effectively react with sea salt particles and displace $\mathrm{HCl}$ gas, leaving behind particles depleted in chloride and enriched in the corresponding organic salts.

The microscopy and spectromicroscopy methods discussed above help visualize particle morphology and internal structure at the nanometer scale (Laskin, 2010; Moffet et al., 2010a) and provide valuable chemical information on elemental composition (SEM/EDX) and organic group functionalities present in particles (STXM/NEXAFS). High resolution Nanospray Desorption Electrospray Ionization (NanoDESI) mass spectrometry on field-collected particles can provide additional detailed information on the molecular structures of organic aerosol species, but this method acquires integrated signal from an ensemble of particles and therefore eliminates knowledge of individual particle composition (Roach et al., 2010). Thus, analyses of the various particle samples collected during CARES will include complementary analytical methods that provide comprehensive information ranging from microscopic details of individual particles to advanced molecular characterization of complex molecules comprising particulate matter.
Other types of offline chemical and radio isotopic analyses of ambient aerosol require large amounts of samples, which were obtained during CARES using several highvolume samplers. Carbon levels in the submicron particle samples taken at the $\mathrm{T} 1$ site with high-volume samplers were found to be quite low, and visual examination indicated little $\mathrm{BC}$ present for most of the study. This result is qualitatively consistent with the measurements of $\mathrm{BC}$ mass by the SP2 at the T1 site. Carbon-14 analysis of four samples collected over 12 and $24 \mathrm{~h}$ periods at the beginning and end of the CARES campaign show that $74 \pm 0.6 \%$ of the carbon was modern, suggesting that there was a significant biogenic component in the carbonaceous aerosols. Furthermore, stable carbon isotopic content $\left(\delta^{13} \mathrm{C}\right)$ for these samples was found to be $-27.5 \pm 3.5 \%$ relative to the Pee Dee Belemnite standard. This is equal to the global average $\delta^{13} \mathrm{C}$ for $\mathrm{C} 3$ plants such as Ponderosa Pines, which dominate the region (Ehleringer and Monson, 1993; Cerling and Harris, 1999). The combined data indicate that a significant amount of the carbonaceous aerosols at this site were from secondary organic carbonaceous aerosols, likely produced from oxidation of isoprene, monoterpenes, and sesquiterpenes by ozone and $\mathrm{OH}$ radicals. Further work on these quartz filter samples is planned, including examination of natural radionuclides $\left({ }^{7} \mathrm{Be}\right.$ and ${ }^{210} \mathrm{~Pb}$ ) as well as use of integrating sphere methods to examine the UV-Visible absorption of the terpene-dominated SOA (Gaffney et al., 2004; Marley et al., 2009).

Another high-volume $\mathrm{PM}_{2.5}$ sampler was deployed at the T0 site from 2-15 June and at the T1 site from 16-28 June. Detailed chemical analysis of these samples is also planned, with a focus on studying the distribution of organic acids and aldehydes with respect to total organic carbon (Jaoui et al., 2004).

\subsection{Optical properties and radiation observations}

\subsubsection{In situ aerosol optical properties}

In situ aerosol optical properties were measured at multiple wavelengths at each site with several instruments, including nephelometer, PSAP, PAS, and CRDS. The flow to the nephelometer and PSAP instruments at each site was subjected to alternating size cutoffs of 1 and $10 \mu \mathrm{m}$ aerodynamic diameters for $6 \mathrm{~min}$ each; the difference between the two gives the scattering and absorption by super-micron particles. Such variable size cutoffs were not applied to flows on other instruments. Nephelometer, PSAP, and PAS instruments were also deployed aboard the G-1. As mentioned earlier, the aerosol inlet on the G-1 allowed transmission of particles up to $5 \mu \mathrm{m}$ aerodynamic diameters, and no additional cutoffs were applied to the flows to the optical instruments. In this report we limit the discussion to the nephelometer, PSAP, and PAS observations at green wavelength to illustrate the behavior and consistency of the scattering and absorption coefficients observed on the three different platforms through the entire 

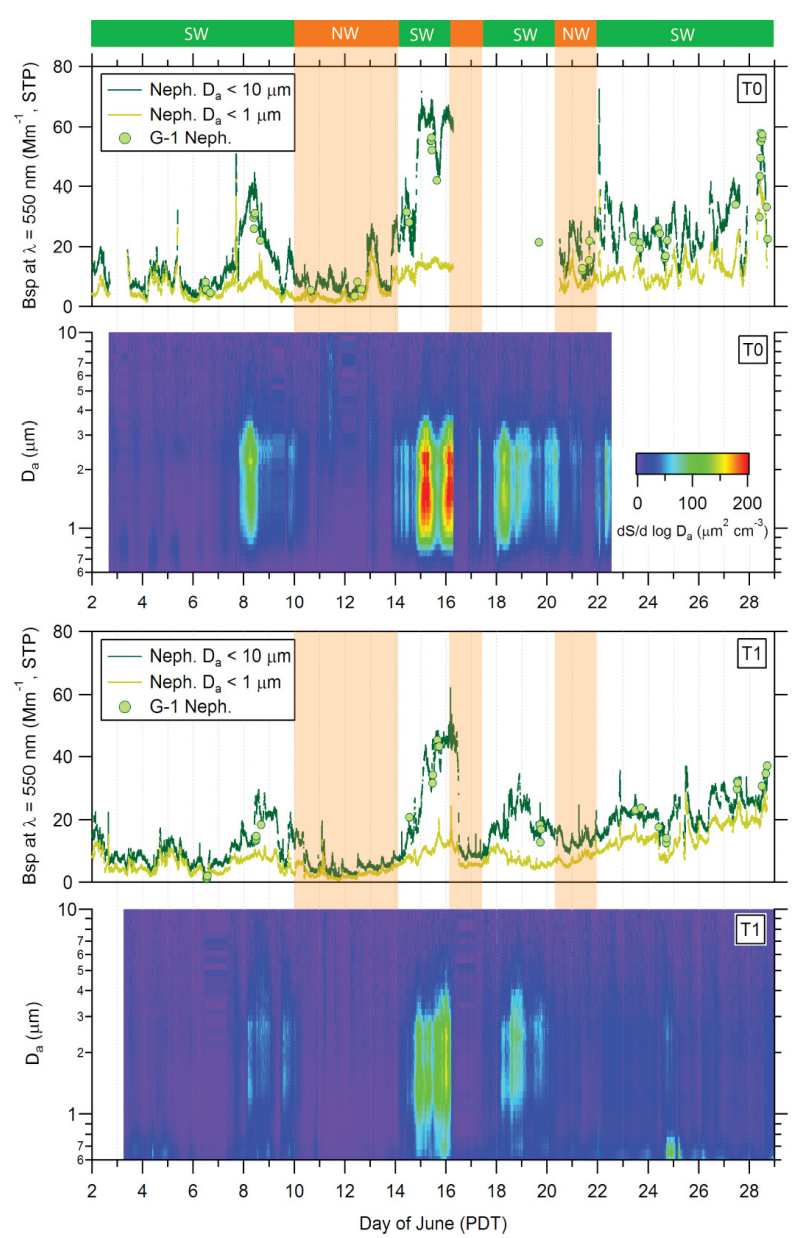

Fig. 18. Comparison of scattering coefficient measured by nephelometer at the T0 and T1 sites and onboard the G-1 during overpasses at the respective sites.

campaign. Detailed analyses of the optical properties at different wavelengths from each instrument and a comparison of observations from all three instruments will be presented in separate papers.

Figure 18 shows the time series of scattering coefficients $\left(B_{\mathrm{sp}}\right)$ measured at $\lambda=550 \mathrm{~nm}$ by the nephelometers along with the surface area size distribution derived from APS measurements at both sites. Also shown are the scattering coefficients observed aboard the G-1 during overpasses at each site. Coarse mode particles were largely absent at both sites during the first week of June and later again during the NW flow periods. During these periods, scattering coefficients for the $1 \mu \mathrm{m}$ cutoff channel were rather low and ranged between 2 and $15 \mathrm{Mm}^{-1}$ while scattering coefficients for the $10 \mu \mathrm{m}$ cutoff channel were only about 2 to $5 \mathrm{Mm}^{-1}$ higher. On days when the surface area size distributions indicate increased presence of coarse mode particles, scattering coefficients for the $10 \mu \mathrm{m}$ cutoff channels reached as high as 40 to $75 \mathrm{Mm}^{-1}$ and 20 to $50 \mathrm{Mm}^{-1}$ at the $\mathrm{T} 0$ and $\mathrm{T} 1$ sites, respectively, and were about 2 to 4 times higher than the values for the $1 \mu \mathrm{m}$

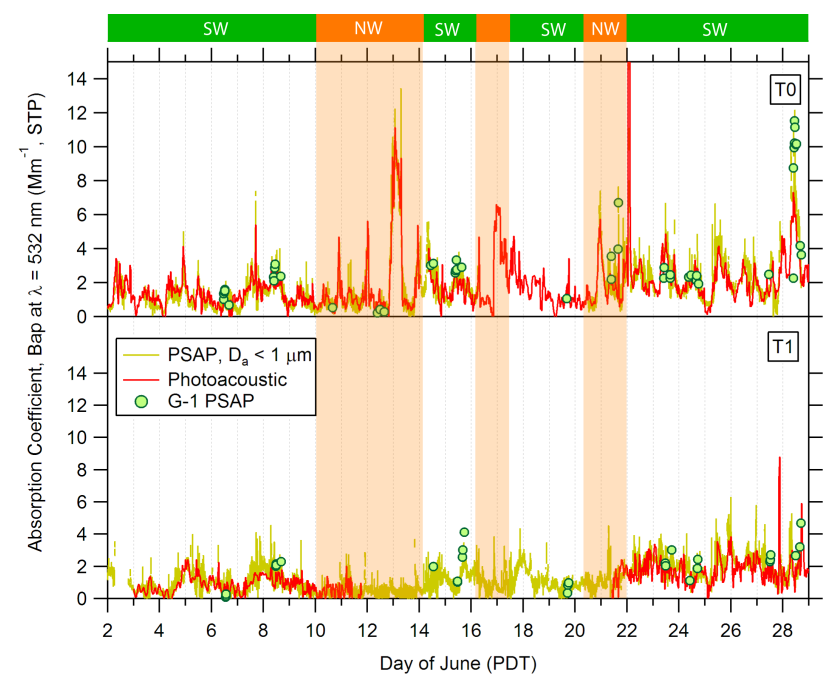

Fig. 19. Comparison of absorption coefficient measured at $\lambda=$ $532 \mathrm{~nm}$ by PSAP and photoacoustic instruments at the T0 and T1 sites and by PSAP $(\lambda=522 \mathrm{~nm})$ aboard the G-1 during overpasses at the respective sites.

cutoff channel at each site. Scattering for both channels at both sites shows a steady increase after 22 June, which is consistent with the steady buildup of submicron size aged aerosols in the region as discussed previously. During this period, the increase in the scattering in the $10 \mu \mathrm{m}$ channel was largely driven by the increase in scattering in the $1 \mu \mathrm{m}$ channel. According to the surface area size distribution data at both sites, about $95 \%$ of the total surface area was present below $5 \mu \mathrm{m}$ aerodynamic diameter when a significant coarse mode was present. Consequently, the scattering coefficients observed aboard the G-1 were in very good agreement with or only slightly smaller than the $10 \mu \mathrm{m}$ cutoff values at both the ground sites during the overpasses, through all periods of low and high concentrations of coarse mode particles.

Figure 19 shows time series of absorption coefficients (Bap) measured by PSAP $\left(D_{\mathrm{a}}<1 \mu \mathrm{m}\right)$ and PAS instruments at $\lambda=532 \mathrm{~nm}$ at both the sites. Also shown are absorption coefficients measured with the PSAP $(\lambda=522 \mathrm{~nm})$ aboard the G-1 during overpasses at each site. The ground sites PSAP data are 1-min averages, the G-1 PSAP data are 10-s averages, and the PAS data are 30-min averages. Through the entire campaign, PSAP absorption coefficients for the $10 \mu \mathrm{m}$ cutoff channel (not shown) were nearly identical to the $1 \mu \mathrm{m}$ cutoff values, indicating that the coarse mode particles were largely non-absorbing at $\lambda=532 \mathrm{~nm}$. The ground sites PSAP and PAS absorption coefficients are in good agreement. The PSAP absorption coefficients observed aboard the G-1 are also in very good agreement with the PSAP and PAS based values at both ground sites during the overpasses. 


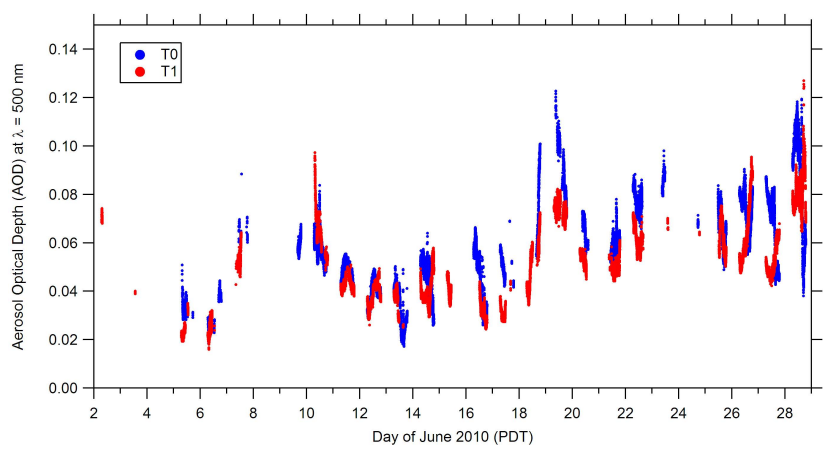

Fig. 20. Comparison of aerosol optical depth derived from MFRSR observations at $\mathrm{T} 0$ and $\mathrm{T} 1$ sites.

\subsubsection{Ground-based remote sensing observations}

A Multi-Filter Rotating Shadowband Radiometer (MFRSR) was deployed at each ground site to measure the total allsky surface downwelling irradiance, and its diffuse and direct components. These were measured at six narrowband $(10 \mathrm{~nm}, \mathrm{FWHM})$ wavelengths centered at 415, 500, 615, 673, 870, and $940 \mathrm{~nm}$ (visible and near-IR spectral region) with 20-s temporal resolution. The measured irradiances were used to obtain column aerosol microphysical and optical properties, such as aerosol optical depth (AOD), single scattering albedo (SSA), and asymmetry parameter, $g$. The high-temporal resolution MFRSR observations at the two sites provided the diurnal, day-to-day, and site-by-site variations of AOD (Fig. 20). For example, the AOD values (at $\lambda=500 \mathrm{~nm}$ ) were observed to range from about 0.025 (which represents very clean air) at the start of the campaign to about 0.12 towards the end of the campaign. Note that there were several cloudy-sky periods when AOD values are not available.

In addition to the AOD values, the MFRSR observations were used to retrieve aerosol microphysical (e.g., size distribution, including fine and coarse size modes) and the intensive optical properties (SSA and $g$ ) using spectrally resolved direct and diffuse irradiances (Kassianov et al., 2007). The original version of this technique has been developed for clear sky conditions. Its updated version (Kassianov et al., 2011) extends the clear-sky aerosol retrievals to partly cloudy conditions, so that aerosol properties can be determined for some cloudy sky conditions. Similar to the AOD, the aerosol size distributions and intensive properties have significant variations over the course of the campaign. To illustrate this we show temporal changes in the aerosol size distribution (a bimodal distribution consisting of fine and coarse modes) retrieved at the two sites (Fig. 21). It is notable that the coarse mode was substantial for several time periods (e.g., during 16 June). In general, the existence of a large coarse mode in the column, as retrieved from the MFRSR measurements, is consistent with measurements of the coarse mode made by the
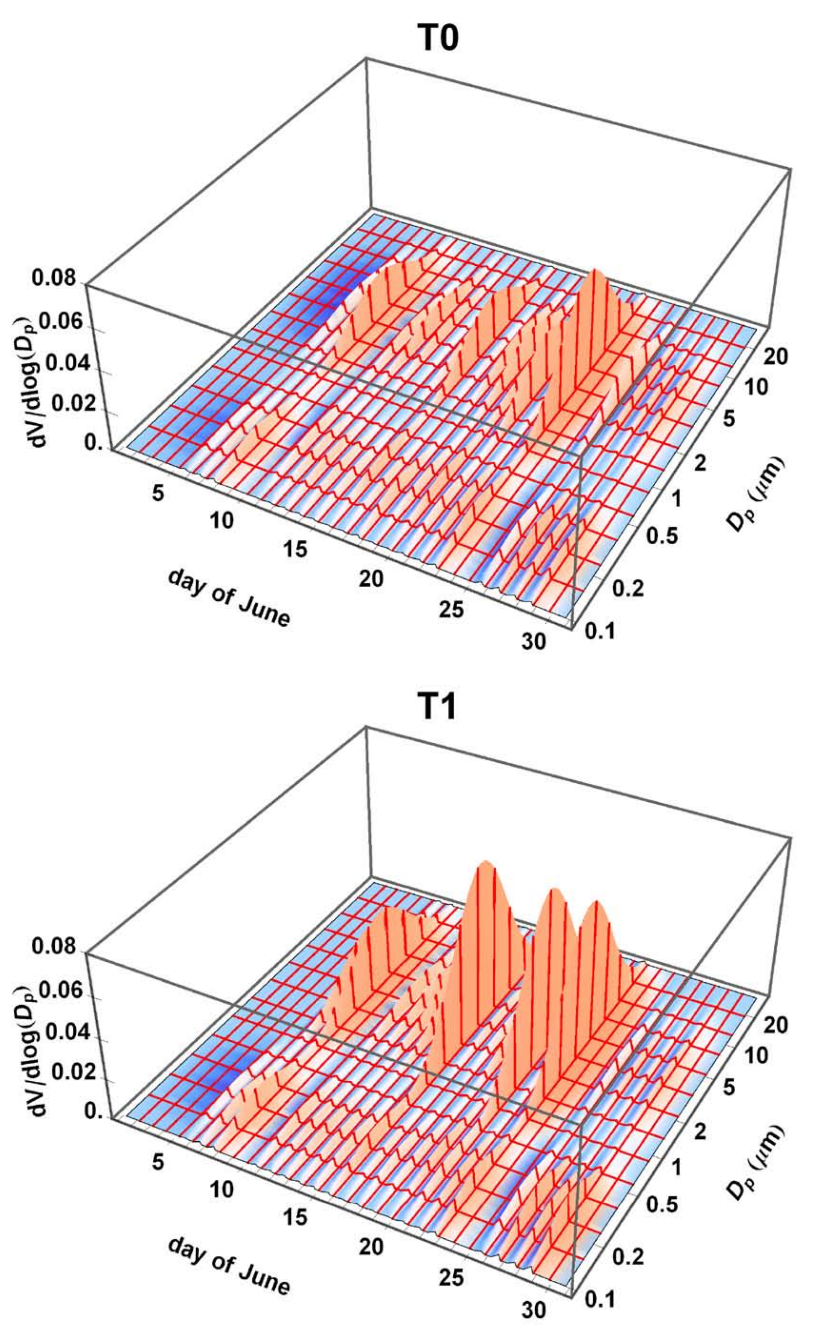

Fig. 21. Daily average volume size distributions derived from MFRSR observations at T0 and T1 ground sites.

APS instruments at the $\mathrm{T} 0$ and $\mathrm{T} 1$ sites (shown previously in Fig. 18).

\subsubsection{Airborne remote sensing observations}

Consistent with the ground sites and G-1 observations, the HSRL measurements aboard the B-200 showed that aerosol extinction and AOD $(532 \mathrm{~nm})$ were generally quite low during CARES; average AOD values (for the layer between 0.1 to $7 \mathrm{~km}$ ) in and around the Sacramento area were generally between 0.05 and 0.1. Smaller values were found earlier during the mission (e.g., 3 and 6 June); larger (>0.1) AOD values were measured later during the mission (e.g., 28 June). The HSRL measurements also showed that much (30-70\%) of the AOD was above the top of the planetary boundary layer (PBL).

The HSRL measurements of aerosol intensive parameters and aerosol optical depth have also been used to identify 
aerosol types and apportion aerosol optical thickness to the various aerosol types (Burton et al., 2012). Eight distinct types with different aerosol intensive properties were identified. The identification of these types were guided by the analyses of Cattrall et al. (2005) and Müller et al. (2007) that provide values of a set of lidar-observed aerosol intensive parameters corresponding to various aerosol types. The HSRL aerosol classification results were used to identify smoke aerosols during the ARCTAS mission (Warneke et al., 2010) and urban aerosols during the MILAGRO mission (Molina et al., 2010).

The HSRL data indicate significant variability in the vertical and horizontal distributions of aerosols during CARES. An example of such aerosol variability is illustrated in Fig. 22 which shows HSRL measurements acquired between 17:45 UT and 18:12 UT on 19 June when the B200 flew from the Sacramento region northeast over the mountains. Aerosol backscatter and AOD decreased as the aircraft flew northeast along the track. The variability of the aerosol intensive parameters (i.e., aerosol depolarization, depolarization spectral ratio, and backscatter wavelength dependence) is indicative of changes in aerosol type. Over Sacramento, lower depolarization and higher backscatter wavelength dependence is consistent with smaller, spherical particles typically seen over urban areas; in contrast, over the mountains east of Sacramento, higher depolarization and smaller backscatter wavelength dependence is consistent with larger, more nonspherical particles often associated with dust.

The HSRL data showed a difference in the backscatter color ratio $(532 / 1064 \mathrm{~nm})$ and aerosol depolarization $(532 \mathrm{~nm})$ between the SW and NW flow regimes discussed in Sects. 4.1 and 4.3.2. These parameters were used to qualitatively classify the HSRL aerosol measurements into several aerosol types. The NW flow suggests larger, more nonspherical particles that, based on the prior observations and the classification scheme, appear like a dusty mix. The SW flow regime suggests, smaller, more spherical particles that are more consistent with urban and occasionally maritime conditions.

\subsection{Aircraft observations of Sacramento plume evolution}

To complement the extensive observations at the $\mathrm{T} 0$ and $\mathrm{T} 1$ sites, the G-1 was deployed on selected days during both SW and NW flow periods to sample upwind of, within, and outside the evolving Sacramento urban plume as it was advected downwind. Other flight plans included sampling the inflow from the Bay Area into the Central Valley and characterizing isoprene emission flux over the forested areas in the Sierra Nevada foothills. An intercomparison flight with the NOAA WP-3 was also carried on 18 June in the San Joaquin Valley, from Fresno to Bakersfield, CA. The G-1 flew at a similar altitude as the WP-3 while the B-200 and NOAA Twin Otter flew above both aircraft. Full analysis of all the aircraft data will be reported in the future. Here we briefly show an example of the G-1, B-200, and NOAA Twin Otter observations in the Sacramento urban plume on 28 June as it was transported under light westerly winds to the foothills area by late afternoon. Figure 23 shows semi-Lagrangian tracks of the G-1 flight in the afternoon, with the points color coded by $\mathrm{CO}$ and (isoprene + methyl vinyl ketone + methacrolein) mixing ratios in the top panels, organic aerosol and BC mass concentrations in the middle panels, and scattering and absorption coefficients in the bottom panels. While the flight began at 14:20 PDT and ended at 17:42 PDT, only the portion of the flight between 15:51 and 16:51 PDT is shown here for clarity. All flight legs in the valley were performed at an altitude of $\sim 340 \mathrm{~m}$ m.s.l. while the leg over the foothills area (passing over the $\mathrm{T} 1$ site) was performed at $\sim 850 \mathrm{~m}$ m.s.l. due to the higher elevation of the terrain.

The Sacramento urban plume is clearly noticeable from the enhanced CO mixing ratios, with highs above $250 \mathrm{ppbv}$ in the plume and lows around $120 \mathrm{ppbv}$ in the surrounding air. Sum of isoprene and its first generation photooxidation products - methyl vinyl ketone (MVK) and methacrolein (MACR) - were around 1 ppbv or less west of T0 and gradually increased to the east, with values between 4 and $8 \mathrm{ppbv}$ over the foothills. Organics constituted more than $90 \%$ of the total observed submicron aerosol mass and was significantly enhanced in the urban plume, with highs over $25 \mu \mathrm{g} \mathrm{m}^{-3}$ STP and lows $\sim 10 \mu \mathrm{g} \mathrm{m}^{-3}$ STP in the surrounding air. BC mass concentrations in the Sacramento plume ranged between 0.1 and $0.2 \mu \mathrm{g} \mathrm{m}^{-3}$ STP and were between 0.03 and $0.07 \mu \mathrm{g} \mathrm{m}^{-3}$ STP in the surrounding air. High BC mass concentrations were also observed in the western-most portion of the flight track, which coincides with Woodland, a relatively small town (population $\sim 50000$ ) located about $25 \mathrm{~km}$ northwest of Sacramento. The nephelometer scattering coefficient in the plume was as high as $54 \mathrm{Mm}^{-1}$ STP and the lows were $\sim 20 \mathrm{Mm}^{-1}$ STP in the surrounding air. Finally, PSAP absorption coefficient tracked with $\mathrm{BC}$ mass concentration and was as high as $\sim 8 \mathrm{Mm}^{-1} \mathrm{STP}$; the values in the surrounding air ranged from $\sim 1$ to $3 \mathrm{Mm}^{-1}$ STP.

Figure 24 shows HSRL measurements of aerosol extinction profiles and AOD values (at $\lambda=532 \mathrm{~nm}$ ) acquired along a portion of the B200 flight track over the Sacramento region during the afternoon of 28 June (15:56 PDT to 17:28 PDT). This portion of the B-200 flight track matched that of the G-1, which acquired comprehensive in situ observations within these lidar "curtains". The height of the boundary layer derived from the HSRL data varied between about 1200-2000 m above ground level. The B-200 aerosol extinction and AOD values were enhanced east of the T0 site and were largest just south of the $\mathrm{T} 1$ site, consistent with the location of the plume as identified from in situ G-1 observations. While the aerosol extinction derived from HSRL measurements appears to be comparable to the estimated in situ extinction values (sum of scattering and absorption), a detailed comparison of the two will be the topic of a separate study. 

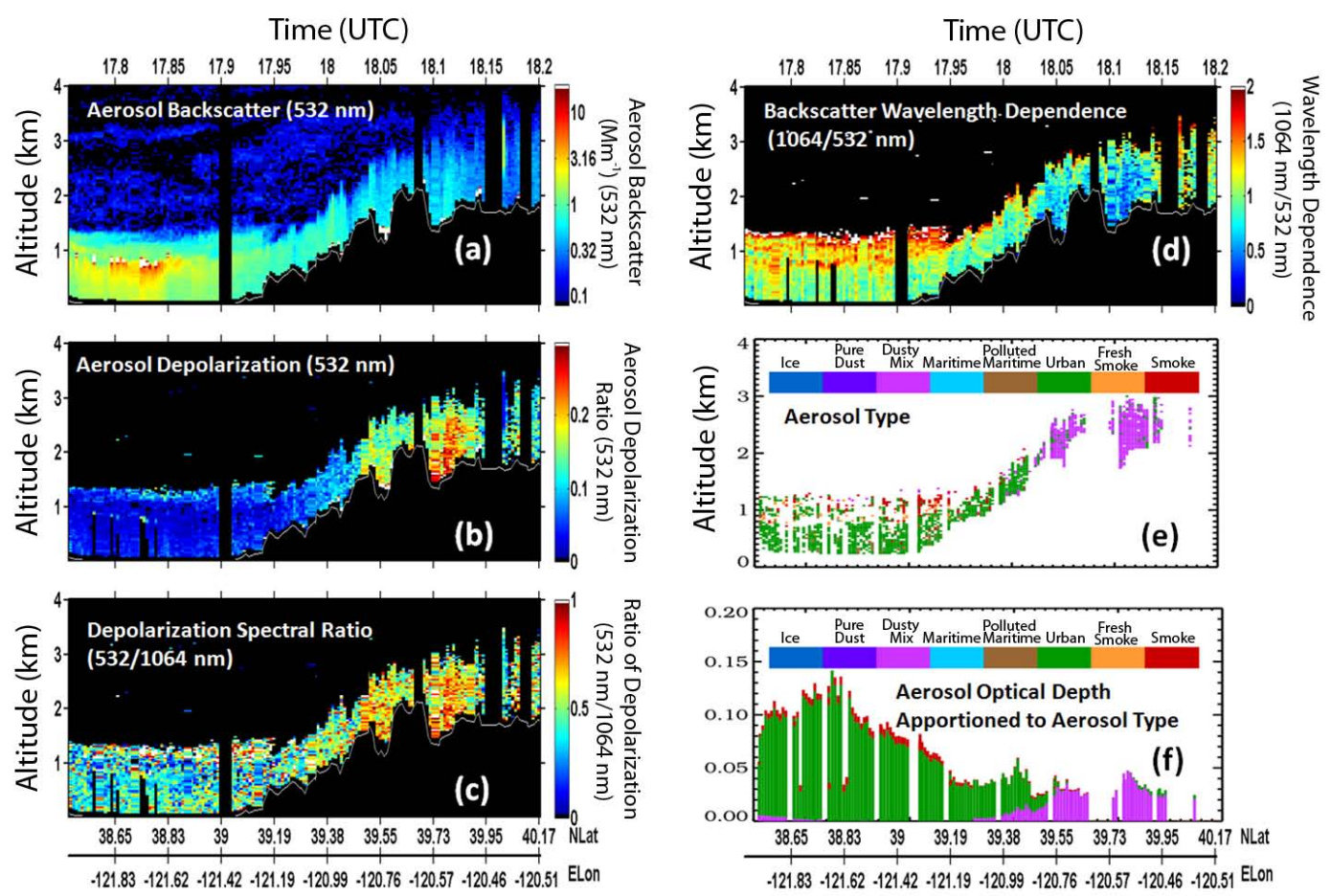

Fig. 22. (a) Aerosol backscatter $(532 \mathrm{~nm})$, (b) aerosol depolarization $(532 \mathrm{~nm})$, (c) ratio of aerosol depolarization (532/1064 nm), (d) backscatter wavelength dependence $((1064 / 532 \mathrm{~nm})$ measured by the airborne HSRL between 17:45-18:12 UT on 19 June. This portion of the B200 flight covered about $160 \mathrm{~km}$ between the Sacramento area (left) and the mountains east of Sacramento (right). The dark area in the bottom part of the images represents the ground surface. (e) Aerosol type inferred from the HSRL measurements of aerosol intensive parameters. (f) AOD apportioned to aerosol type.

Figure 25 depicts ozone profiles observed with the TOPAZ lidar (Fig. 25a) and $\mathrm{NO}_{2}$ vertical column densities (VCD) measured with the CU AMAX DOAS (Fig. 25b) along the NOAA Twin Otter flight track over the Sacramento area on 28 June for two flight segments from 11:28-12:03 and 13:04-13:52 PDT. The TOPAZ lidar data clearly show the elevated ozone concentrations in the Sacramento plume downwind to the east of the city. Peak ozone concentrations in the plume approach $125 \mathrm{ppbv}$ and were measured about $30 \mathrm{~km}$ to the east of Sacramento at about 13:40 PDT. Mixing heights were generally between 800 and $1100 \mathrm{~mm}$.s.l., except $1500 \mathrm{~m}$ m.s.l. or higher within the core of the Sacramento plume. The Twin Otter data were taken about three hour prior to the G-1 and B-200 observations shown in Figs. 23 and 24. The Sacramento plume had not yet progressed as far east as shown by the G-1 and B-200 measurements and was just approaching the base of the Sierra Nevada Foothills south of the T1 site. Mixing heights were lower by several hundred meters compared to the B-200 observations, which is consistent with a midday convective boundary layer that is still growing. The CU AMAX-DOAS data showed significant variability in the $\mathrm{NO}_{2} \mathrm{VCD}$ below the aircraft. The boundary conditions upwind of Sacramento are characterized by an elevated yet variable $\mathrm{NO}_{2} \mathrm{VCD}$ in the range 3 to $4 \times 10^{15}$ molecule $\mathrm{cm}^{-2}$, or 1.2 and $1.7 \mathrm{ppb}$
$\mathrm{NO}_{2}$ averaged over the mixed air column. Along the west to east transect passing over the Sacramento urban core, a distinct increase in the $\mathrm{NO}_{2} \mathrm{VCD}$ is observed near the city center, indicating $\mathrm{NO}_{\mathrm{x}}$ emissions most likely from mobile sources. The $\mathrm{NO}_{2} \mathrm{VCD}$ reaches peak values above $1 \times 10^{16}$ molecule $\mathrm{cm}^{-2}$ over the urban core, and decreases to about half that value about $15 \mathrm{~km}$ to the east of Sacramento. No significant suppression of $\mathrm{O}_{3}$ is observed over the city center. Rather, in the area of peak $\mathrm{NO}_{2}$ also $\mathrm{O}_{3}$ increases simultaneously and immediately, reflecting hydrocarbon to $\mathrm{NO}_{\mathrm{x}}$ ratios that are favorable for fast photochemical $\mathrm{O}_{3}$ production in the Sacramento plume. The $\mathrm{O}_{3}$ background levels upwind $(50 \mathrm{ppb})$ increase along this flight track to $80 \mathrm{ppb}$ near the $\mathrm{NO}_{2}$ maximum, and peak $\mathrm{O}_{3}$ exceeds 100 ppb only about $15 \mathrm{~km}$ to the east of Sacramento. The $\mathrm{NO}_{2}$ VCDs measured by CU AMAX-DOAS provide unique column integral data over mixing height that are insensitive to model errors in predicting mixing height. The column data facilitate a direct comparison to model predicted $\mathrm{NO}_{2} \mathrm{VCDs}$, and enable more direct testing of the $\mathrm{NO}_{\mathrm{x}}$ emission inventory in the Sacramento area. Accurate $\mathrm{NO}_{\mathrm{x}}$ emissions are prerequisite for predicting photochemical $\mathrm{O}_{3}$ production by chemical transport models. In principle, the combination of the TOPAZ lidar and CU AMAX-DOAS can also be used to constrain $\mathrm{O}_{\mathrm{x}}$ (sum of 

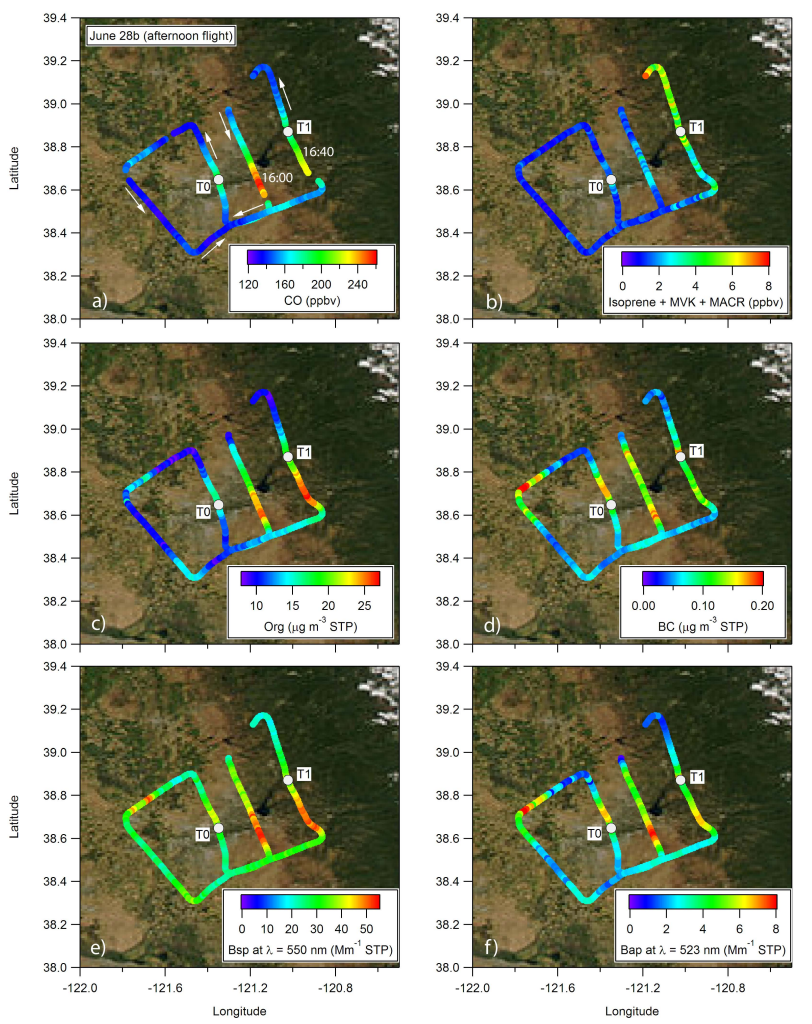

Fig. 23. Semi-Lagrangian G-1 flight tracks on the afternoon of 28 June, with the points color coded by: (a) CO, (b) sum of isoprene, methyl vinyl ketone (MVK), and methacrolein (MACR), (c) organic aerosol mass concentration, (d) BC mass concentration, (e) Nephelometer scattering coefficient at $\lambda=550 \mathrm{~nm}$, and (f) PSAP absorption coefficient at $\lambda=523 \mathrm{~nm}$.

$\mathrm{O}_{3}+\mathrm{NO}_{2}$ ), which is a useful metric for characterizing photochemical formation of SOA.

\section{Summary and future directions}

The CARES field campaign was designed to examine the interaction between anthropogenic and biogenic emissions in SOA formation, black carbon ageing, and their effects on the associated optical and CCN activation properties. The campaign was carried out from 2-28 June 2010, in Central Valley, California, centered on the Sacramento urban area. Two heavily-instrumented ground sites - one within the Sacramento urban area (site T0) and another in Cool, CA, a small town about $40 \mathrm{~km}$ to the northeast in the foothills area (site T1) - were set up to characterize the evolution of meteorological variables, trace gases, aerosol precursors, aerosol size, composition, and optical and CCN activation properties in freshly polluted and aged urban air. On selected days, the DOE G-1 aircraft was deployed to make similar measurements upwind and across the evolving Sacramento plume in the morning and again in the afternoon. The NASA B-
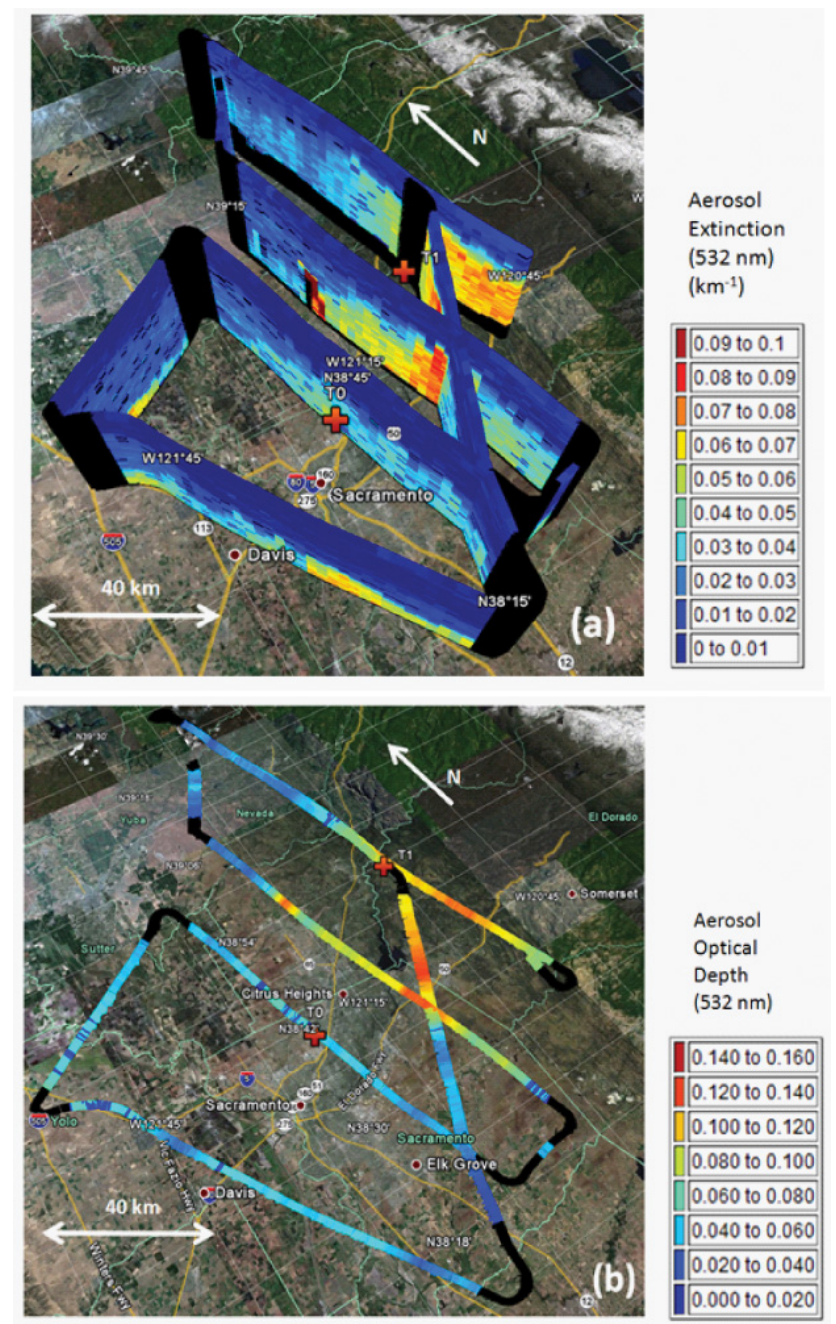

Fig. 24. (a) Aerosol extinction $(532 \mathrm{~nm})$ profiles derived from airborne HSRL measurements acquired over the Sacramento region between 15:56 PDT and 17:28 PDT on 28 June. Profiles between the surface and $3 \mathrm{~km}$ altitude are shown. (b) AOD derived from the HSRL measurements along this same flight track. In both panels the locations of the $\mathrm{T} 0$ and $\mathrm{T} 1$ ground sites are indicated by red crosses.

200 aircraft, carrying remote sensing instruments (HSRL and RSP), was also deployed to characterize the vertical and horizontal distribution of aerosols and aerosol optical properties within and around the plume. The CARES campaign overlapped temporally with the CalNex campaign in the Central Valley and Southern California regions in May and June 2010. As part of CalNex, the NOAA Twin Otter aircraft, carrying a combination of downward-looking ozone/aerosol and Doppler wind lidars and a multi-axis DOAS system, moved its operation from Southern California to Sacramento to collaborate with CARES from 14-28 June. The main initial findings from the CARES campaign are summarized below:

- On approximately 20 days out of a total of 27, the Sacramento urban plume transport was largely controlled by 

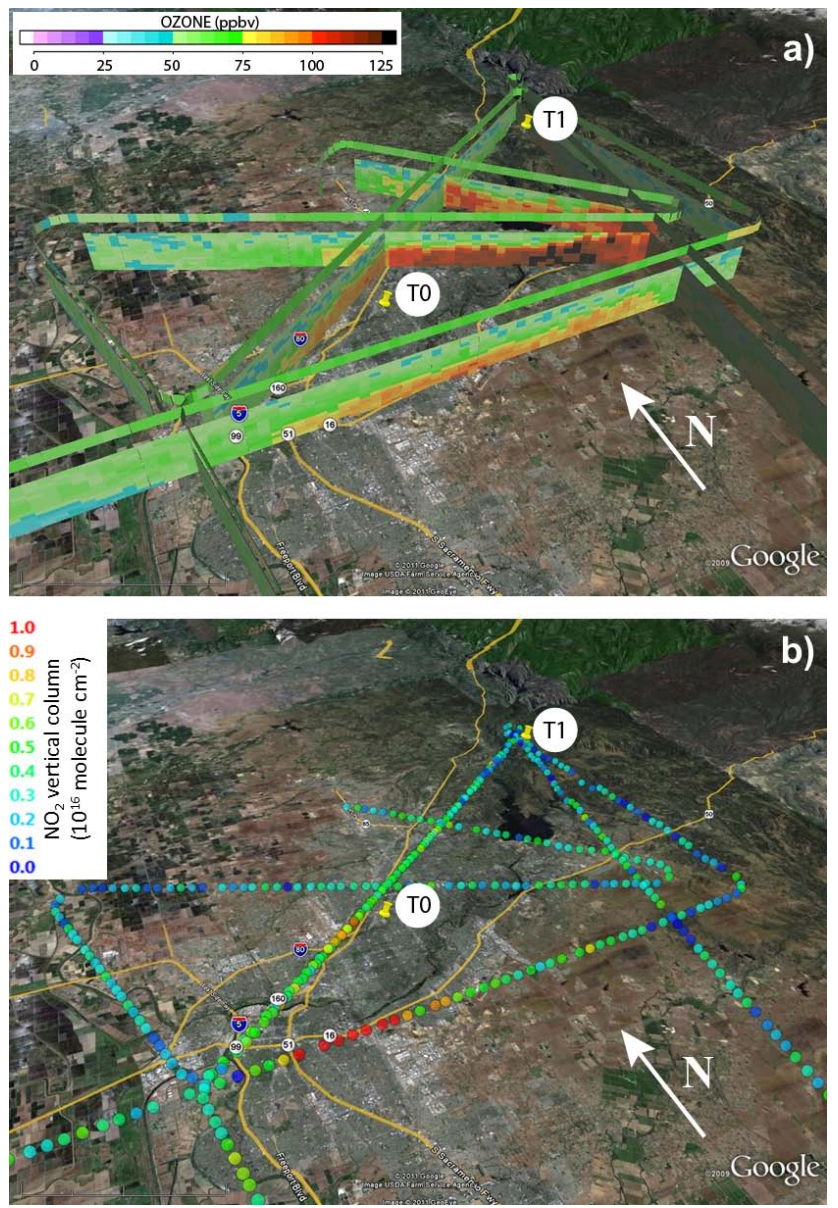

Fig. 25. (a) Ozone mixing ratio profiles measured with the TOPAZ lidar and (b) $\mathrm{NO}_{2}$ vertical column densities measured with the CU AMAX DOAS system over the Sacramento area on 28 June. Data are from two flight segments from 11:28-12:03 and 13:0413:52 PDT. The ozone profiles extend from near the ground to $1500 \mathrm{~m}$ m.s.l. The colored line above the ozone "curtain" plot represents the ozone in situ measurements at flight level (approx. $2100 \mathrm{~m}$ m.s.1.). The locations of the T0 and T1 ground sites are indicated by yellow pushpin markers.

southwesterly winds that drew the polluted air to the northeast over the forested areas in the Sierra Nevada foothills where it mixed with biogenic emissions by late afternoon or early evening. On the remaining $\sim 7$ days (10-13, 16, and 20-21 June), the southwesterly wind pattern was interrupted by northwesterly flows, which transported the Sacramento plume to the southeast into the San Joaquin Valley, where there was relatively much less mixing with biogenic emissions.

- The period from 22-28 June also experienced a steady buildup of aged aerosols due to recirculation of air in the region, coupled with warmer temperatures toward the end of June. These conditions resulted in the highest pollution days at the end of the campaign, from 25-
28 June. Observations across the relatively cleaner and more polluted periods as well as across the SW and NW flow regimes thus provide an exceptional opportunity to examine aerosol formation and evolution processes in the same region under a range of environmental conditions.

- The urban site T0 experienced significantly higher mixing ratios of the primary emission species such as $\mathrm{CO}$, $\mathrm{NO}_{\mathrm{y}}$, and anthropogenic VOCs compared to the rural foothills site T1, and the diurnal behaviors of these species were also similar to each other, as expected. In contrast, the diurnal behavior of biogenic isoprene mixing ratios at both the sites followed that of the surface temperatures. The peak mixing ratios ranged between 2 and 12 ppbv around 14:00 PDT while the minimum mixing ratios were nearly zero from midnight until dawn. Since the T1 site was located amidst biogenic emissions, isoprene mixing ratios there were generally about 0.5 to 3 ppbv higher than at $\mathrm{T} 0$. The diurnal behavior of photochemically produced $\mathrm{O}_{3}$ at the $\mathrm{T} 0$ and $\mathrm{T} 1$ sites were quite similar despite the marked differences in the precursor trace gas composition and concentrations between the two sites. The highs ranged between 60 and $80 \mathrm{ppbv}$, except for a peak of nearly $120 \mathrm{ppbv}$ on 28 June. The daily $\mathrm{O}_{3}$ peaks at $\mathrm{T} 0$ typically occurred around 15:00 PDT while it was often delayed by $\sim 3 \mathrm{~h}$ at $\mathrm{T} 1$ on days when the urban plume was transported to the site during the SW flow periods.

- Sub-micron non-refractory aerosol composition observed at both the ground sites and aboard the G-1 aircraft was dominated by organics, followed by sulfate, followed by nitrate and ammonium, while chloride was negligibly small. OA concentrations at the ground sites ranged between $<0.5$ and $10 \mu \mathrm{g} \mathrm{m}^{-3} \mathrm{STP}$ and displayed a diurnal cycle that was similar to that of $\mathrm{O}_{3}$ at both sites, which is consistent with photochemical production of SOA from anthropogenic and biogenic VOCs. OA concentrations typically peaked at the T0 site around 15:00 PDT while it peaked around 18:00 PDT or later at the T1 site as the urban plume was transported to the foothills area during the SW flow periods. Enhanced concentrations of aged organic aerosols, likely recirculated from the foothills area the previous day, were often observed in the residual layer during the morning flights over the Sacramento urban area, which is consistent with preliminary WRF simulation results presented in Fast et al. (2012). The period from 22-28 June experienced a steady buildup of OA, with concentrations reaching more than $25 \mu \mathrm{g} \mathrm{m}^{-3}$ STP aloft in the urban plume as it was transported east to the foothills area on the afternoon of the 28th.

- On selected days during both SW and NW flow periods, the daytime evolution of key trace gases, aerosol 
composition, mixing state, size distribution, and optical properties in the Sacramento urban plume was observed by the G-1 as it sampled upwind of, across, and downwind of the drifting plume in the morning and afternoon. These semi-Lagrangian in situ observations were complemented by NASA B-200 observations of vertical profiles of aerosol optical properties, which provided a more complete picture of the 3-dimensional structure of the evolving urban plume and the surrounding air. In the latter half of the campaign, this picture was further enhanced by NOAA Twin Otter observations of vertical profiles of $\mathrm{O}_{3}, \mathrm{NO}_{2}, \mathrm{HCHO}, \mathrm{CHOCHO}$, and wind speed in Sacramento and surrounding areas.

- Single particle mass spectrometers (SP-MS) deployed on the G-1 (A-ATOFMS), at T0 (SPLAT II), and at T1 (PALMS) also showed that the vast majority of aerosol particles characterized during the study were composed of oxygenated organics mixed with various amounts of sulfates: from sulfate-dominated particles to those containing mostly organic species. In addition, fresh and processed soot particles, biomass burning aerosol, amines, sea salt (both fresh and processed), and a small number of mineral dust and other inorganic particles were observed. The A-ATOFMS provided semi-Lagrangian aerial snapshots of particle mixing states in the evolving urban plume. In contrast, the SPLAT II, which was operated almost continuously for the entire campaign period, provided a detailed view of the evolution of relative fractions of different primary and secondary particle types in a single day, albeit at a fixed urban site. Size- and composition-selected SOAdominated particles were also analyzed using SPLAT II to study evaporation kinetics at room temperature (Vaden et al., 2011a). This study is the first to present field evidence that evaporation of these ambient organic particles was extremely slow and size-independent, suggesting that the particles were in a quasi-solid state.

- SP2 instruments (outfitted with a scattering channel) deployed on the G-1 and at both the ground sites provided data on $\mathrm{BC}$ number and mass concentrations for particles between 60 and $600 \mathrm{~nm}$ BC mass equivalent diameters as well as coating state data for particles between $\sim 175$ and $350 \mathrm{~nm}$. Preliminary analysis of G-1 SP2 data for 28 June showed an increase in the coating mass to $\mathrm{BC}$ mass ratio in the urban plume between the morning and afternoon flights. Particles were also collected using TRAC and DRUM samplers on all three platforms for offline analyses to further probe the chemical composition, mixing state, and morphology.

- $\mathrm{SO}_{2}$ emitted from oil refineries in the Bay Area appears to have been routinely transported to the Sacramento area during the $\mathrm{SW}$ flow periods. These $\mathrm{SO}_{2}$ plumes were associated with increased number concen- trations of ultrafine and Aitken mode particles, which were likely nucleated via $\mathrm{H}_{2} \mathrm{SO}_{4}$ formation from $\mathrm{SO}_{2}$ photooxidation, followed by growth to the observed sizes during transit. The Aitken mode was typically observed at both the ground sites in the morning around 09:30 PDT, followed by continued growth to accumulation mode sizes until mid-afternoon, likely due to condensation of photochemically formed SOA species. In contrast, $\mathrm{SO}_{2}$ mixing ratios were negligibly small and the Aitken mode aerosol number concentrations were also significantly lower in the sampling domain during the NW flow periods.

- Coarse mode aerosols, mostly consisting of sea salt, were found to be transported from the Pacific Ocean/Bay Area to the Sacramento area on several occasions during the SW flow periods. Electron microscopy and X-ray spectro-microscopy analysis of TRAC collected particles onboard the G-1 over Sacramento on 15 June (a strong SW flow event) revealed that the sea salt particles were internally mixed with organics, which are likely SOA species formed in these particles during transit from the Bay Area. Surprisingly, these particles had experienced substantial chloride depletion that could not be explained by the known reactivity of sea salt with nitric and sulfuric acids (Laskin et al., 2012). This study is the first to present field evidence that SOA, consisting of weak organic acids, may effectively react with sea salt particles and displace $\mathrm{HCl}$ gas, leaving behind particles depleted in chloride and enriched in the corresponding organic salts.

- In situ aerosol optical properties were measured at near$\mathrm{UV}$ and visible spectral regions onboard the G-1 and at $\mathrm{T} 0$ and $\mathrm{T} 1$ ground sites with several instruments, including nephelometer, PSAP, and PAS. A CRDS instrument was also deployed at the ground sites. When the coarse mode particles were present, the scattering coefficients $(\lambda=550 \mathrm{~nm})$ reached as high as 40 to $75 \mathrm{Mm}^{-1}$ and 20 to $50 \mathrm{Mm}^{-1}$ at the T0 and T1 sites, respectively, and were about 2 to 4 times higher than the scattering coefficients of submicron particles. In contrast, the scattering coefficients ranged between 4 and $20 \mathrm{Mm}^{-1}$ when the coarse mode particles were largely absent during first week of June and later again during the NW flow periods. MFRSR observations at each ground site provided the diurnal, day-to-day, and site-by-site variations in column aerosol microphysical and optical properties, such as aerosol optical depth, single scattering albedo, and asymmetry parameter. Consistent with the in situ optical properties measurements, MFRSR AOD values were observed to range from about 0.025 (representing very clean air) at the start of the campaign to about 0.12 towards the end of the campaign. Additionally, coarse aerosol mode size distributions derived from MFRSR 
data were also found to be consistent with the in situ size distribution measurements at both ground sites.

- Observations of CCN concentrations are also available at multiple supersaturations $(0.07$ to $0.5 \%)$ at both ground sites. The $\mathrm{T} 1$ site also included measurement of size-resolved CCN concentrations and variable relative humidity nephelometry (commonly referred to as $f(\mathrm{RH})$ measurement).

The CARES measurements have been processed and uploaded into the final ARM data archive (http://campaign. arm.gov/cares). These measurements comprise a rich data set for: (1) investigating SOA formation from anthropogenic and biogenic precursors and the potential interactions between them; (2) characterizing the time scales of BC ageing and evolution of its mixing state; and (3) quantifying the roles of BC mixing state, organics, and coarse mode aerosols on the observed optical and CCN activation properties. As mentioned throughout this paper, several detailed studies using various CARES data are planned or presently underway and will be reported via subsequent publications in this special issue and elsewhere as appropriate. Here we briefly summarize some of the key science questions that can be investigated using CARES data.

\subsection{Secondary organic aerosols}

1. Can we reliably infer IVOC (and SVOC) concentrations in the urban air, how they varied diurnally and scaled with VOC and CO concentrations, and how did these aerosol precursor gases correlate with organic aerosol number and mass concentrations in freshly polluted urban air?

2. What were the chemical composition, volatility spectrum, and hygroscopicity of OA, and how did they evolve as a function of atmospheric processing time and photochemical age?

3. Is there evidence for enhanced SOA formation in the urban plume when it mixed with biogenic emissions (e.g., during southwesterly flow conditions) compared to instances when the urban plume did not mix with biogenic emissions (e.g., during northwesterly flow conditions)? Can the observed SOA in the aged urban plume be separated into anthropogenic and biogenic fractions using carbon isotope analyses and other methods based on PTRMS observations and positive matrix factorization of AMS mass spectra?

4. How did the size distribution of aerosols evolve with SOA formation in the urban plume? Does the SOA condensation kinetics appear to be driven by Raoult's Law type gas absorption thermodynamics or is it similar to that of a condensing non-volatile species?
5. What was the role of organic species in the observed growth of ultrafine particles to $\mathrm{CCN}$ and optically active sizes?

\subsection{Aerosol mixing state}

1. What was the distribution of $\mathrm{BC}$ mass fraction (BC mixing state) as a function of particle size in fresh and aged urban plumes? How rapidly did POA, BC, SOA, and inorganics become internally mixed?

2. What were the relative roles of condensation and coagulation processes in shaping the aerosol composition and size distribution?

3. What were the contributions and mixing states of other primary emissions such as biomass burning aerosol, mineral dust and sea salt, and how did these aerosols evolve?

4. What were the effects of aerosol mixing state on the ensemble aerosol optical properties, hygroscopicity, and CCN activity?

\subsection{Aerosol optical properties}

1. What was the role of changes in $\mathrm{BC}$ mixing state and morphology on enhanced light absorption?

2. Was there increased (by OA over BC) near-UV absorption? Did OA absorption extend into the visible part of the spectrum? If so, how did it relate to OA composition?

3. What were the absolute and relative contributions of sub-micron and super-micron aerosols to the total aerosol direct radiative forcing?

4. Which compounds or particle types have the strongest radiative impacts, and can these be related to specific emission sources or atmospheric formation processes?

The resulting detailed picture for the evolution of different types of carbonaceous aerosols and their optical and $\mathrm{CCN}$ activation properties will then help improve the key aerosol process and property modules that are used in regional and global climate models. Specific modeling studies that are planned by CARES participants include:

- Local closures for optical and CCN activation properties.

- Constrained Lagrangian modeling of SOA formation and interactions between anthropogenic and biogenic emissions.

- Constrained Lagrangian modeling of black carbon mixing state evolution. 
- Regional simulations of SOA formation that include long-range transport of trace gases and aerosols.

- Assessments of new treatments of SOA and aerosol mixing state on aerosol optical and hygroscopic properties and their impact on radiative forcing over California and surrounding regions.

In closing, it is reiterated that the purpose of this early overview paper is to summarize the scientific objectives, the platforms and instrumentation, the sampling strategies, and the key observations collected during the campaign, and develop an initial list of specific science questions that could be investigated with the CARES data set. It is hoped that this paper will facilitate further analyses of this remarkably rich data set as well as stimulate ideas for novel, collaborative studies.

\section{Supplementary material related to this article is available online at: http://www.atmos-chem-phys.net/12/ 7647/2012/acp-12-7647-2012-supplement.pdf.}

Acknowledgements. The authors thank the DOE G-1, NASA Langley B-200 King Air, and NOAA Twin Otter flight crew and numerous staff from all the involved institutions for their outstanding work in support of the CARES field mission. The contributions and cooperation of the following in this research effort are gratefully acknowledged: Eileen McCauley, Ajith Kaduwela, James Pederson, Leon Dolislager, and colleagues at California Air Resources Board (CARB) for their assistance in planning this study; Anthony Wexler (UC Davis), Ron Cohen (UC Berkeley), and Allen Goldstein (UC Berkeley) for helpful discussions during the planning stages of the study; John Ogren and his group at NOAA for their assistance with aerosol rack and data collection during the campaign; Ms. Wendy Westsmith and the staff at Northside School in Cool, Mr. Laduan Smedley and the staff at American River College in Sacramento, and staff at McClellan Airfield for the use of their facilities. Funding for data collection onboard the G-1 aircraft and at the ground sites was provided by the Atmospheric Radiation Measurement (ARM) Program sponsored by the US Department of Energy (DOE), Office of Biological and Environmental Research (OBER). Partial support was also provided by the Environmental Molecular Sciences Laboratory (EMSL), a national scientific user facility sponsored by the DOE's OBER at Pacific Northwest National Laboratory (PNNL). Funding for the B-200/HSRL/RSP deployment and investigations came from the NASA HQ Science Mission Directorate Radiation Sciences Program, the NASA CALIPSO project, and the DOE ARM Program, Interagency Agreement No. DE-AI02-05ER63985. Funding for data collection and analysis of the measurements taken onboard the NOAA Twin Otter was provided by the NOAA Health of the Atmosphere Program. Participation of R. Volkamer, S. Baidar, H. Oetjen, and I. Ortega (University of Colorado, Boulder) was made possible by the California Air Resources Board contract 09-317, and NSF-CAREER award AGS-0847793. Participation of A. Kubátová and H. Jeong (University of North Dakota) was made possible by funding from ND EPSCoR through NSF grant \#EPS-814442. Participation of C. D. Cappa and K. R. Kolesar (University of California, Davis) was made possible by funding from NOAA and US EPA. This research was also supported by the US DOE's Atmospheric System Research (ASR) Program under Contract DE-AC06-76RLO 1830 at PNNL. PNNL is operated for the US DOE by Battelle Memorial Institute.

Edited by: G. McFiggans

\section{References}

Adachi, K. and Buseck, P. R.: Internally mixed soot, sulfates, and organic matter in aerosol particles from Mexico City, Atmos. Chem. Phys., 8, 6469-6481, doi:10.5194/acp-8-6469-2008, 2008.

Adachi, K., Chung, S. H., and Buseck, P. R.: Shapes of soot aerosol particles and implications for their effects on climate, J. Geophys. Res., 115, D15206, doi:10.1029/2009JD012868, 2010.

Aiken, A. C., DeCarlo, P. F., Kroll, J. H., Worsnop, D. R., Huffman, J. A., Docherty, K. S., Ulbrich, I. M., Mohr, C, Kimmel, J. R., Sueper, D., Sun, Y., Zhang, Q., Trimborn, A., Northway, M., Ziemann, P. J., Canagaratna, M. R., Onasch, T. B., Alfarra, M. R., Prévôt, A. S. H., Dommen, J., Duplissy, J., Metzger, A., Baltensperger, U., and Jimenez, J. L.: O/C and OM/OC Ratios of Primary, Secondary, and Ambient Organic Aerosols with a High Resolution Time-of-Flight Aerosol Mass Spectrometer, Environ. Sci. Technol., 42, 4478-4485, doi:4410.1021/es703009q, 2008.

Alvarez II, R. J., Senff, C. J., Langford, A. O., Weickmann, A. M., Law, D. C., Machol, J. L., Merritt, D. A., Marchbanks, R. D., Sandberg, S. P., Brewer, W. A., Hardesty, R. M., and Banta, R. M.: Development and application of a compact, tunable, solidstate airborne ozone lidar system for boundary layer profiling, J. Atmos. Ocean. Tech., 28, 1258-1272, doi:10.1175/JTECH-D10-05044.1, 2011.

Anderson, T. L., Covert, D. S., Marshalll, S. F., Laucks, M. L, Charlson, R. J., Waggoner, A. P., Ogren, J. A., Caldow, R., Holm, R. L., Quant, F. R., Sem, G. J., Wiedensohler, A., Ahlquist, N. A., and Bates, T. S.: Performance characteristics of a high-sensitivity, three-wavelength total scatter/backscatter nephelometer, J. Atmos. Ocean. Tech., 13, 967-986, 1996.

Andreae, M. O. and Gelencsér, A.: Black carbon or brown carbon? The nature of light-absorbing carbonaceous aerosols, Atmos. Chem. Phys., 6, 3131-3148, doi:10.5194/acp-6-3131-2006, 2006.

Arnott, W. P., Moosmuller, H., Rogers, C. F., Jin, T. F., and Bruch, R.: Photoacoustic spectrometer for measuring light absorption by aerosol: instrument description, Atmos. Environ., 33, 28452852, 1999.

Barsanti, K. C. and Pankow, J. F.: Thermodynamics of the formation of atmospheric organic particulate matter by accretion reactions - 2. Dialdehydes, methylglyoxal, and diketones, Atmos. Environ., 39, 6597-6607, 2005.

Bauer, S. E., Wright, D. L., Koch, D., Lewis, E. R., McGraw, R., Chang, L.-S., Schwartz, S. E., and Ruedy, R.: MATRIX (Multiconfiguration Aerosol TRacker of mIXing state): an aerosol microphysical module for global atmospheric models, 
Atmos. Chem. Phys., 8, 6003-6035, doi:10.5194/acp-8-60032008, 2008.

Baumgardner, D., Jonsson, H., Dawson, W., O'Connor, D., and Newton, R.: The cloud, aerosol and precipitation spectrometer: a new instrument for cloud investigations, Atmos. Res., 59-60, 251-264, doi:10.1016/S0169-8095(01)00119-3, 2001.

Bergstrom, R. W., Russell, P. B., and Hignett, P.: Wavelength dependence of the absorption of black carbon particles: Predictions and results from the TARFOX experiment and implications for the aerosol single scattering albedo, J. Atmos. Sci., 59, 567-577, 2002.

Bond, T. C.: Can warming particles enter global climate discussions?, Environ. Res. Lett., 2, 045030, doi:10.1088/17489326/2/4/045030, 2007.

Bond, T. C., Habib, G., and Bergstrom, R. W.: Limitations in the enhancement of visible light absorption due to mixing state, J. Geophys. Res., 111, D20211, doi:10.1029/2006JD007315, 2006.

Bones, D. L., Henricksen, D. K., Mang, S. A., Gonsior, M., Bateman, A. P., Nguyen, T. B., Cooper, W. J., and Nizkorodov, S. A.: Appearance of strong absorbers and fluorophores in limonene$\mathrm{O} 3$ secondary organic aerosol due to $\mathrm{NH}_{4}+$-mediated chemical aging over long time scales, J. Geophys. Res., 115, D05203, doi:10.1029/2009JD012864, 2010.

Bruns, E. A., Perraud, V., Zelenyuk, A., Ezell, M. J., Johnson, S. N., Yu, Y., Imre, D., Finlayson-Pitts, B. J., and Alexander, M. L.: Comparison of FTIR and particle mass spectrometry for the measurement of particulate organic nitrates, Environ. Sci. Technol., 44, 1056-1061, 2010.

Bueno, P. A., Havey, D. K., Mulholland, G. W., Hodges, J. T., Gillis, K. A., Dickerson, R. R., and Zachariah, M. R.: Photoacoustic measurements of amplification of the absorption cross section for coated soot aerosols, Aerosol Sci. Technol., 45, 1217-1230, doi:10.1080/02786826.2011.587477, 2011.

Burton, S. P., Ferrare, R. A., Hostetler, C. A., Hair, J. W., Rogers, R. R., Obland, M. D., Butler, C. F., Cook, A. L., Harper, D. B., and Froyd, K. D.: Aerosol classification using airborne High Spectral Resolution Lidar measurements - methodology and examples, Atmos. Meas. Tech., 5, 73-98, doi:10.5194/amt-5-73-2012, 2012.

Buzorius, G., Zelenyuk, A., Brechtel, F., and Imre, D.: Simultaneous determination of individual ambient particle size, hygroscopicity and composition, Geophys. Res. Lett., 29, 1974, doi:10.1029/2001GL014221, 2002.

Cai, Y., Montague, D. C., Mooiweer-Bryan, W., and Deshler, T.: Performance characteristics of the ultra high sensitivity aerosol spectrometer for particles between 55 and $800 \mathrm{~nm}$ : Laboratory and field studies, J. Aerosol Sci., 39, 759-769, doi:10.1016/j.jaerosci.2008.04.007, 2008.

Canagaratna, M., Jayne, J., Jimenez, J. L., Allan, J. A., Alfarra, R., Zhang, Q., Onasch, T., Drewnick, F., Coe, H., Middlebrook, A., Delia, A., Williams, L., Trimborn, A., Northway, M., DeCarlo, P., Kolb, C., Davidovits, P., and Worsnop, D.: Chemical and microphysical characterization of ambient aerosols with the Aerodyne aerosol mass spectrometer, Mass Spectrom. Rev., 26, 185-222, doi:110.1002/mas.20115, 2007.

Cantrell, W., Shaw, G., Cass, G. R., Chowdhury, Z., Hughes, L. S., Prather, K. A., Guazzotti, S. A., and Coffee, K. R.: Closure between aerosol particles and cloud condensation nuclei at Kaashidhoo Climate Observatory, J. Geophys. Res., 106, 28711-
28718, doi:10.1029/2000JD900781, 2001.

Cappa, C. D., Lack, D. A., Burkholder, J. B., and Ravishankara, A. R.: Bias in filter-based aerosol light absorption measurements due to organic aerosol loading: Evidence from laboratory measurements, Aerosol Sci. Technol., 42, 1022-1032, 2008.

Cattrall, C., Reagan, J., Thome, K., and Dubovik, O.: Variability of aerosol and spectral lidar and backscatter and extinction ratios of key aerosol types derived from selected Aerosol Robotic Network locations, J. Geophys. Res., 110, D10S11, doi:10.1029/2004JD005124, 2005.

Cerling, T. E. and Harris, J. M.: Carbon isotope fractionation between diet and bioapatite in ungulate mammals and implications for ecological and paleoecological studies, Oecologia, 120, 347363, 1999.

Cross, E. S., Onasch, T. B., Ahern, A., Wrobel, W., Slowik, J. G., Olfert, J., Lack, D. A., Massoli, P., Cappa, C. D., Schwarz, J. P., Spackman, J. R., Fahey, D. W., Sedlacek, A., Trimborn, A., Jayne, J. T., Freedman, A., Williams, L. R., Ng, N. L., Mazzoleni, C., Dubey, M., Brem, B., Kok, G., Subramanian, R., Freitag, S., Clarke, A., Thornhill, D., Marr, L. C., Kolb, C. E., Worsnop, D. R., and Davidovits, P.: Soot particle studies - Instrument intercomparison - Project overview, Aerosol Sci. Technol., 44, 592611, doi:10.1080/02786826.2010.482113, 2010.

Cziczo, D. J., Thomson, D. S., Thompson, T. L., DeMott, P. J., and Murphy, D. M.: Particle analysis by laser mass spectrometry (PALMS) studies of ice nuclei and other low number density particles, Int. J. Mass Spectrom., 258, 21-29, 2006.

Cubison, M. J., Ervens, B., Feingold, G., Docherty, K. S., Ulbrich, I. M., Shields, L., Prather, K., Hering, S., and Jimenez, J. L.: The influence of chemical composition and mixing state of Los Angeles urban aerosol on CCN number and cloud properties, Atmos. Chem. Phys., 8, 5649-5667, doi:10.5194/acp-8-5649-2008, 2008.

de Haan, D. O., Corrigan, A. L., Smith, K.W., Stroik, D. R., Turley, J. J., Lee, F. E., Tolbert, M. A., Jimenez, J. L., Cordova, K. E., and Ferrell, G. R.: Secondary organic aerosol-forming reactions of glyoxal with amino acids, Environ. Sci. Tech., 43, 2818-2824, 2009a.

de Haan, D. O., Tolbert, M. A., and Jimenez, J. L.: Atmospheric condensed-phase reactions of glyoxal with methylamine, Geophys. Res. Lett., 36, L11819, doi:11810.11029/12009GL037441, 2009b.

Delene, D. J. and Ogren, J. A.: Variability of Aerosol Optical Properties at Four North American Surface Monitoring Sites, J. Atmos. Sci., 59, 1135-1150, 2002.

Doran, J. C., Fast, J. D., Barnard, J. C., Laskin, A., Desyaterik, Y., and Gilles, M. K.: Applications of lagrangian dispersion modeling to the analysis of changes in the specific absorption of elemental carbon, Atmos. Chem. Phys., 8, 1377-1389, doi:10.5194/acp-8-1377-2008, 2008.

Dzepina, K., Volkamer, R. M., Madronich, S., Tulet, P., Ulbrich, I. M., Zhang, Q., Cappa, C. D., Ziemann, P. J., and Jimenez, J. L.: Evaluation of recently-proposed secondary organic aerosol models for a case study in Mexico City, Atmos. Chem. Phys., 9, 5681-5709, doi:10.5194/acp-9-5681-2009, 2009.

Duarte, R. M. B. O., Pio, C. A., and Duarte, A. C.: Spectroscopic study of the water-soluble organic matter isolated from atmospheric aerosols collected under different atmospheric conditions, Anal. Chim. Acta, 530, 7-14, 2005. 
Ehleringer, J. R. and Monson, R. K.: Evolutionary and ecological aspects of photosynthetic pathway variation, Ann. Rev. Ecolog. Syst., 24, 411-439, 1993.

Ervens, B. and Kreidenweis, S. M.: SOA formation by biogenic and carbonyl compounds: Data evaluation and application, Environ. Sci. Technol., 41, 3904-3910, 2007.

Erickson, M. H., Wallace, H. W., and Jobson, B. T.: Quantification of diesel exhaust gas phase organics by a thermal desorption proton transfer reaction mass spectrometer, Atmos. Chem. Phys. Discuss., 12, 5389-5423, doi:10.5194/acpd-125389-2012, 2012.

Farmer, D. K., Matsunaga, A., Dochterty, K. S., Surratt, J. D., Seinfeld, J. H., Ziemann, P. J., and Jimenez, J. L.: Response of an aerosol mass spectrometer to organonitrates and organosulfates and implications for atmospheric chemistry, P. Natl. Acad. Sci. USA, 107, 6670-6675, 2010.

Fast, J. D., Gustafson Jr., W. I., Easter, R. C., Zaveri, R. A., Barnard, J. C., Chapman, E. G., Grell, G. A., and Peckham, S. E.: Evolution of ozone, particulates, and aerosol direct radiative forcing in the vicinity of Houston using a fully coupled meteorology-chemistry-aerosol model, J. Geophys. Res., 111, D21305, doi:10.1029/2005JD006721, 2006.

Fast, J. D., Gustafson Jr., W. I., Berg, L. K., Shaw, W. J., Pekour, M., Shrivastava, M., Barnard, J. C., Ferrare, R. A., Hostetler, C. A., Hair, J. A., Erickson, M., Jobson, B. T., Flowers, B., Dubey, M. K., Springston, S., Pierce, R. B., Dolislager, L., Pederson, J., and Zaveri, R. A.: Transport and mixing patterns over Central California during the carbonaceous aerosol and radiative effects study (CARES), Atmos. Chem. Phys., 12, 1759-1783, doi:10.5194/acp-12-1759-2012, 2012.

Flowers, B. A., Dubey, M. K., Mazzoleni, C., Stone, E. A., Schauer, J. J., Kim, S.-W., and Yoon, S. C.: Optical-chemicalmicrophysical relationships and closure studies for mixed carbonaceous aerosols observed at Jeju Island; 3-laser photoacoustic spectrometer, particle sizing, and filter analysis, Atmos. Chem. Phys., 10, 10387-10398, doi:10.5194/acp-10-10387-2010, 2010.

Fierz, M., Vernooij, M. G. C., and Burtscher, H.: An improved lowflow thermodenuder, J. Aerosol Sci., 38, 1163-1168, 2007.

Forster, P., Ramaswamy, V., Artaxo, P., Berntsen, T., Betts, R., Fahey, D. W., Haywood, J., Lean, J., Lowe, D. C., Myhre, G., Nganga, J., Prinn, R., Raga, G., Schulz, M., and Van Dorland, R.: Changes in Atmospheric Constituents and in Radiative Forcing, in: Climate Change 2007: The Physical Science Basis. Contribution of Working Group I to the Fourth Assessment Report of the Intergovernmental Panel on Climate Change, edited by: Solomon, S., Qin, D., Manning, M., Chen, Z., Marquis, M., Averyt, K. B., Tignor, M., and Miller, H. L., 129-234, Cambridge Univ. Press, Cambridge, United Kingdom and New York, NY, USA, 2007.

Fuller, K. A., Malm, W. C., and Kriedenweis, S. M.: Effects of mixing on extinction by carbonaceous particles, J. Geophys. Res., 104, 15941-15954, 1999.

Furutani, H., Dall'osto, M., Roberts, G. C., and Prather, K. A.: Assessment of the relative importance of atmospheric aging on CCN activity derived from field observations, Atmos. Environ., 42, 3130-3142, doi:10.1016/j.atmosenv.2007.09.024, 2008.

Gaffney, J. S., Marley, N. A., and Cunningham, M. M.: Natural radionuclides in fine aerosols in the Pittsburgh area, Atmos. Environ., 38, 3191-3200, 2004.
Gao, R. S., Schwarz, J. P., Kelly, K. K., Fahey, D. W., Watts, L. A., Thompson, T. L., Spackman, J. R., Slowik, J. G., Cross, E. S., Han, J.-H., Davidovits, P., Onasch, T. B., and Worsnop, D. R.: A novel method for estimating light-scattering properties of soot aerosols using a modified single-particle soot photometer, Aerosol Sci. Tech., 41 125-135, 2007.

Ghan, S. J. and Schwartz, S. E.: Aerosol properties and processes: A Path from field and laboratory measurements to global climate models, B. Am. Meteorol. Soc., 88, 1059-1083, 2007.

Grell, G. A., Peckham, S. E., Schmitz, R., McKeen, S. A., Frost, G., Skamarock, W. C., and Eder, B.: Fully coupled "online" chemistry within the WRF model, Atmos. Environ., 39, 6957-6975, 2005.

Guenther, A., Karl, T., Harley, P., Wiedinmyer, C., Palmer, P. I., and Geron, C.: Estimates of global terrestrial isoprene emissions using MEGAN (Model of Emissions of Gases and Aerosols from Nature), Atmos. Chem. Phys., 6, 3181-3210, doi:10.5194/acp-63181-2006, 2006.

Gyawali, M., Arnott, W. P., Lewis, K., and Moosmüller, H.: In situ aerosol optics in Reno, NV, USA during and after the summer 2008 California wildfires and the influence of absorbing and non-absorbing organic coatings on spectral light absorption, Atmos. Chem. Phys., 9, 8007-8015, doi:10.5194/acp-9-8007-2009, 2009.

Gyawali, M., Arnott, W. P., Zaveri, R. A., Song, C., Moosmüller, H., Liu, L., Mishchenko, M. I., Chen, L.-W. A., Green, M. C., Watson, J. G., and Chow, J. C.: Photoacoustic optical properties at UV, VIS, and near IR wavelengths for laboratory generated and winter time ambient urban aerosols, Atmos. Chem. Phys., 12, 2587-2601, doi:10.5194/acp-12-2587-2012, 2012.

Hair, J. W., Hostetler, C. A., Cook, A. L., Harper, D. B., Ferrare, R. A., Mack, T. L., Welch, W., Izquierdo, L. R., and Hovis, F. E.: Airborne High Spectral Resolution Lidar for profiling aerosol optical properties, Appl. Optics, 47, 6734-6752, 2008.

Harrison, L., Michalsky, J., and Berndt, J.: Automated Multifilter Rotating Shadow-Band Radiometer: An instrument for optical depth and radiation measurements, Appl. Optics, 33, 5118-5125, 1994.

Hasegawa, S. and Ohta, S.: Some measurements of the mixing state of soot-containing particles at urban and non-urban sites, Atmos. Environ., 36, 3899-3908, 2002

Hastings, W. P., Koehler, C. A., Bailey, E. L., and De Haan, D. O.: Secondary organic aerosol formation by glyoxal hydration and oligomer formation: Humidity effects and equilibrium shifts during analysis, Environ. Sci. Technol., 39, 8728-8735, 2005.

Havers, N., Burba, P., Lambert, J., and Klockow, D.: Spectroscopic characterization of humic-like substances in airborne particulate matter, J. Atmos. Chem., 29, 45-54, 1998.

Hecobian, A., Zhang, X., Zheng, M., Frank, N., Edgerton, E. S., and Weber, R. J.: Water-Soluble Organic Aerosol material and the light-absorption characteristics of aqueous extracts measured over the Southeastern United States, Atmos. Chem. Phys., 10, 5965-5977, doi:10.5194/acp-10-5965-2010, 2010.

Herich, H., Kammermann, L., Friedman, B., Gross, D. S., Weingartner, E., Lohmann, U., Spichtinger, P., Gysel, M., Baltensperger, U., and Cziczo, D. J.: Subarctic atmospheric aerosol composition: 2. Hygroscopic growth properties, J. Geophys. Res., 114, D13204, doi:10.1029/2008JD011574, 2009. 
Hiranuma, N., Kohn, M., Pekour, M. S., Nelson, D. A., Shilling, J. E., and Cziczo, D. J.: Droplet activation, separation, and compositional analysis: laboratory studies and atmospheric measurements, Atmos. Meas. Tech., 4, 2333-2343, doi:10.5194/amt-42333-2011, 2011.

Hodzic, A., Jimenez, J. L., Madronich, S., Canagaratna, M. R., DeCarlo, P. F., Kleinman, L., and Fast, J.: Modeling organic aerosols in a megacity: potential contribution of semi-volatile and intermediate volatility primary organic compounds to secondary organic aerosol formation, Atmos. Chem. Phys., 10, 5491-5514, doi:10.5194/acp-10-5491-2010, 2010.

Hoffer, A., Gelencsér, A., Guyon, P., Kiss, G., Schmid, O., Frank, G. P., Artaxo, P., and Andreae, M. O.: Optical properties of humic-like substances (HULIS) in biomass-burning aerosols, Atmos. Chem. Phys., 6, 3563-3570, doi:10.5194/acp-6-3563-2006, 2006.

Hopkins, R. J., Desyaterik, Y., Tivanski, A. V., Zaveri, R. A., Berkowitz, C. M., Tyliszczak, T., Gilles, M. K., and Laskin, A.: Chemical speciation of sulfur in marine cloud droplets and particles: Analysis of individual particles from the marine boundary layer over the California current, J. Geophys. Res., 113, D04209, doi:10.1029/2007JD008954, 2008.

Jacobson, M. Z.: Strong radiative heating due to the mixing state of black carbon in atmospheric aerosols, Nature, 409, 695-697, 2001.

Jacobson, M. Z.: Control of fossil-fuel particulate black carbon and organic matter, possibly the most effective method of slowing global warming, J. Geophys. Res., 107, 4410, doi:10.1029/2001JD001376, 2002.

Jacobson, M. Z.: Effects of externally-through-internally-mixed soot inclusions within clouds and precipitation on global climate, J. Phys. Chem. A, 110, 6860-6873, doi:10.1021/jp056391r, 2006.

Jaoui, M., Kleindienst, T. E., Lewandowski, M., Offenberg, J. H., and Edney, E. O.: Identification and quantification of aerosol polar oxygenated compounds bearing carboxylic or hydroxyl groups. 2. Organic tracer compounds from monoterpenes, Environ. Sci. Technol., 39, 5661-5673, 2005.

Johnson, K. S., Zuberi, B., Molina, L. T., Molina, M. J., Iedema, M. J., Cowin, J. P., Gaspar, D. J., Wang, C., and Laskin, A.: Processing of soot in an urban environment: case study from the Mexico City Metropolitan Area, Atmos. Chem. Phys., 5, 3033-3043, doi:10.5194/acp-5-3033-2005, 2005.

Kamphus, M., Ettner-Mahl, M., Klimach, T., Drewnick, F., Keller, L., Cziczo, D. J., Mertes, S., Borrmann, S., and Curtius, J.: Chemical composition of ambient aerosol, ice residues and cloud droplet residues in mixed-phase clouds: single particle analysis during the Cloud and Aerosol Characterization Experiment (CLACE 6), Atmos. Chem. Phys., 10, 8077-8095, doi:10.5194/acp-10-8077-2010, 2010.

Kanakidou, M., Seinfeld, J. H., Pandis, S. N., Barnes, I., Dentener, F. J., Facchini, M. C., Van Dingenen, R., Ervens, B., Nenes, A., Nielsen, C. J., Swietlicki, E., Putaud, J. P., Balkanski, Y., Fuzzi, S., Horth, J., Moortgat, G. K., Winterhalter, R., Myhre, C. E. L., Tsigaridis, K., Vignati, E., Stephanou, E. G., and Wilson, J.: Organic aerosol and global climate modelling: a review, Atmos. Chem. Phys., 5, 1053-1123, doi:10.5194/acp-5-1053-2005, 2005.
Kassianov, E. I., Flynn, C. J., Ackerman, T. P., and Barnard, J. C.: Aerosol single-scattering albedo and asymmetry parameter from MFRSR observations during the ARM Aerosol IOP 2003, Atmos. Chem. Phys., 7, 3341-3351, doi:10.5194/acp-7-3341-2007, 2007.

Kassianov, E., Barnard, J. C., Berg, L. K., Long, C. N., and Flynn, C. J.: Shortwave spectral radiative forcing of cumulus clouds from surface observations, Geophys. Res. Lett., 38, L07801, doi:10.1029/2010GL046282, 2011.

Kirchstetter, T. W., Novakov, T., and Hobbs, P. V.: Evidence that the spectral dependence of light absorption by aerosols is affected by organic carbon, J. Geophys. Res., 109, D21208, doi:10.1029/2004JD004999, 2004.

Kleinman, L. I., Daum, P. H., Lee, Y.-N., Senum, G., Springston, S. R., Wang, J., Berkowitz, C., Hubbe, J., Zaveri, R. A., Brechtel, F. J., Jayne, J. T., and Onasch, T. B.: Aircraft observations of aerosol composition in New England and Mid-Atlantic States during the summer 2002 NEAQS Field Campaign, J. Geophys. Res., 112, D09310, doi:10.1029/2006JD007786, 2007.

Knobelspiesse, K., Cairns, B., Ottaviani, M., Ferrare, R., Hair, J., Hostetler, C., Obland, M., Rogers, R., Redemann, J., Shinozuka, Y., Clarke, A., Freitag, S., Howell, S., Kapustin, V., and McNaughton, C.: Combined retrievals of boreal forest fire aerosol properties with a polarimeter and lidar, Atmos. Chem. Phys., 11, 7045-7067, doi:10.5194/acp-11-7045-2011, 2011.

Kondo, Y., Sahu, L., Moteki, N., Khan, F., Takegawa, N., Liu, X., Koike, M., and Miyakawa, T.: Consistency and traceability of black carbon measurements made by laser-induced incandescence, thermal-optical transmittance, and filter-based photoabsorption techniques, Aerosol Sci. Technol., 45, 295-312, doi:10.1080/02786826.2010.533215, 2011.

Kroll, J. H. an d Seinfeld, J. H.: Chemistry of secondary organic aerosol: Formation and evolution of low-volatility organics in the atmosphere, Atmos. Environ., 42, 3593-3624, 2008.

Kulkarni, P. and Wang, J.: New fast integrated mobility spectrometer for real-time measurement of aerosol size distribution: II. Design, calibration, and performance characterization, J. Aerosol Sci., 37, 1326-1339, 2006.

Kuwata, M., Kondo, Y., Mochida, M., Takegawa, N., and Kawamura, K., Dependence of CCN activity of less volatile particles on the amount of coating observed in Tokyo, J. Geophys. Res., 112, D11207, doi:10.1029/2006JD007758, 2007.

Lack, D. A., Lovejoy, E. R., Baynard, T., Pettersson, A., and Ravishankara, A. R.: Aerosol absorption measurement using photoacoustic spectroscopy: Sensitivity, calibration, and uncertainty developments, Aerosol Sci. Technol., 40, 697-708, 2006.

Lack, D. A., Cappa, C. D., Covert, D. S., Baynard, T., Massoli, P., Sierau, B., Bates, T. S., Quinn, P. K., Lovejoy, E. R., and Ravishankara, A. R.: Bias in filter-based aerosol light absorption measurements due to organic aerosol loading: Evidence from ambient measurements, Aerosol Sci. Technol., 42, 1033-1041, doi:10.1080/02786820802389277, 2008.

Laborde, M., Schnaiter, M., Linke, C., Saathoff, H., Naumann, K.H., Möhler, O., Berlenz, S., Wagner, U., Taylor, J. W., Liu, D., Flynn, M., Allan, J. D., Coe, H., Heimerl, K., Dahlkötter, F., Weinzierl, B., Wollny, A. G., Zanatta, M., Cozic, J., Laj, P., Hitzenberger, R., Schwarz, J. P., and Gysel, M.: Single Particle Soot Photometer intercomparison at the AIDA chamber, Atmos. Meas. Tech. Discuss., 5, 3519-3573, doi:10.5194/amtd-5-3519- 
2012, 2012.

Langford, A. O., Senff, C. J., Alvarez II, R. J., Banta, R. M., Hardesty, R. M., Parrish, D. D., and Ryerson, T. B.: Comparison between the TOPAZ airborne ozone lidar and in situ measurements during TexAQS 2006, J. Atmos. Ocean. Tech., 28, 1243-1257, doi:10.1175/JTECH-D-10-05043.1, 2011.

Langridge, J. M., Richardson, M. S., Lack, D., Law, D., and Murphy, D. M.: Aircraft instrument for comprehensive characterization of aerosol optical properties, Part I: Wavelength-dependent optical extinction and its relative humidity dependence measured using cavity ringdown spectroscopy, Aerosol Sci. Technol., 45, 1305-1318, 2011.

Laskin, A.: Electron Beam Analysis and Microscopy of Individual Particles, Fundamentals and Applications in Aerosol Spectroscopy, edited by: Signorell, R. and Reid, J. P., CRC Press Taylor and Francis Group, Boca Raton, 2010.

Laskin, A., Cowin, J. P., and Iedema, M. J.: Analysis of individual environmental particles using modern methods of electron microscopy and X-ray microanalysis, J. Electron Spectroscopy, 150, 260-274, 2006.

Laskin, A., Moffet, R. C., Gilles, M. K., Fast, J. D., Zaveri, R. A., Wang, B., Nigge, P., and Shutthanandan, J.: Tropospheric chemistry of internally mixed sea salt and organic particles: Surprising reactivity of $\mathrm{NaCl}$ with weak organic acids, J. Geophys. Res.., 117, D15302, doi:10.1029/2012JD017743, in press, 2012.

Lee-Taylor, J., Madronich, S., Aumont, B., Camredon, M., Hodzic, A., Tyndall, G. S., Apel, E., and Zaveri, R. A.: Explicit modeling of organic chemistry and secondary organic aerosol partitioning for Mexico City and its outflow plume, Atmos. Chem. Phys. Discuss., 11, 17013-17070, doi:10.5194/acpd-11-170132011, 2011.

Li, J., Pósfai, M., Hobbs, P. V., and Buseck, P. R.: Individual aerosol particles from biomass burning in southern Africa: 2. Compositions and aging of inorganic particles, J. Geophys. Res., 108, 8484, doi:10.1029/2002JD002310, 2003.

Liggio, J., Li, S. M., and McLaren, R.: Heterogeneous reactions of glyoxal on particulate matter: Identification of acetals and sulfate esters, Environ. Sci. Technol., 39, 1532-1541, 2005.

Lesins, G., Chylek, P., and Lohmann, U.: A study of internal and external mixing scenarios and its effect on aerosol optical properties and direct radiative forcing, J. Geophys. Res., 107, 4094, doi:10.1029/2001JD000973, 2002.

Levy, H., Schwarzkopf, M. D., Horowitz, L., Ramaswamy, V., and Findell, K. L.: Strong sensitivity of late 21 st century climate to projected changes in short-lived air pollutants, J. Geophys. Res., 113, D06102, doi:10.1029/2007JD009176, 2008.

Lewis, K., Arnott, W. P., Moosmuller, H., and Wold, C. E.: Strong spectral variation of biomass smoke light absorption and single scattering albedo observed with a novel dual wavelength photoacoustic instrument, J. Geophys. Res., 113, D16203, doi:10.1029/2007JD009699, 2008.

Limbeck, A., Kulmala, M., and Puxbaum, H.: Secondary organic aerosol formation in the atmosphere via heterogeneous reaction of gaseous isoprene on acidic particles, Geophys. Res. Lett., 30, 1996, doi:10.1029/2003GL017738, 2003.

Lukacs, H., Gelencser, A., Hammer, S., Puzbaum, H., Pio, C., Legrand, M., Kasper-Giebl, A., Handler, M., Limbeck, A., Simpson, D., and Preunkert, S.: Seasonal trends and possible sources of brown carbon based on 2-year aerosol measure- ments at six sites in Europe, J. Geophys. Res., 112, D23S18, doi:10.1029/2006JD008151, 2007.

Marley, N. A., Gaffney, J. S., Tackett, M., Sturchio, N. C., Heraty, L., Martinez, N., Hardy, K. D., Marchany-Rivera, A., Guilderson, T., MacMillan, A., and Steelman, K.: The impact of biogenic carbon sources on aerosol absorption in Mexico City, Atmos. Chem. Phys., 9, 1537-1549, doi:10.5194/acp-9-1537-2009, 2009.

Martins, J. V., Artaxo, P., Liousse, C., Reid, J. S., Hobbs, P. V., and Kaufman, Y. J.: Effects of black carbon content, particle size, and mixing on light absorption by aerosols from biomass burning in Brazil, J. Geophys. Res., 103, 32041-32050, 1998.

Medina, J., Nenes, A., Sotiropoulou, R.-E. P., Cottrell, L. D., Ziemba, L. D., Beckman, P. J., and Griffin, R. J.: Cloud condensation nuclei closure during the International Consortium for Atmospheric Research on Transport and Transformation 2004 campaign: Effects of size-resolved composition, J. Geophys. Res., 112, D10S31, doi:10.1029/2006JD007588, 2007.

Mochida, M., Kuwata, M., Miyakawa, T., Takegawa, N., Kawamura, K., and Kondo, Y.: Relationship between hygroscopicity and cloud condensation nuclei activity for urban aerosols in Tokyo, J. Geophys. Res., 111, D23204, doi:10.1029/2005JD006980, 2006.

Moffet, R. C. and Prather, K. A.: Extending ATOFMS measurements to include refractive index and density, Anal. Chem., 77, 6535-6541, 2005.

Moffet, R. C., Tivanski, A. V., and Gilles, M. K.: "Scanning Transmission X-ray Microscopy" in Fundamentals and Applications in Aerosol Spectroscopy, Eds. R. Signorell and J. Reid, CRC Press Taylor and Francis Group, Boca Raton, FL, 419-462, 2010a.

Moffet, R. C., Henn, T., Laskin, A., and Gilles, M. K.: Automated chemical analysis of internally mixed aerosol particles using Xray spectromicroscopy at the carbon K-edge, Anal. Chem., 82, 7906-7914, doi:10.1021/ac1012909, 2010b.

Moffet, R. C., Henn, T. R., Tivanski, A. V., Hopkins, R. J., Desyaterik, Y., Kilcoyne, A. L. D., Tyliszczak, T., Fast, J., Barnard, J., Shutthanandan, V., Cliff, S. S., Perry, K. D., Laskin, A., and Gilles, M. K.: Microscopic characterization of carbonaceous aerosol particle aging in the outflow from Mexico City, Atmos. Chem. Phys., 10, 961-976, doi:10.5194/acp-10-961-2010, 2010c.

Moffet, R. C., Furutani, H. F., Rodel, T., Henn, T., Sprau, P. O., Prakash, S., Laskin, A., Uematsu, M., and Gilles, M. K.: Iron speciation and mixing in single aerosol particles from the Asian continental outflow, J. Geophys. Res., 117, D07204, doi:10.1029/2011JD016746, 2012.

Molina, L. T., Madronich, S., Gaffney, J. S., Apel, E., de Foy, B., Fast, J., Ferrare, R., Herndon, S., Jimenez, J. L., Lamb, B., Osornio-Vargas, A. R., Russell, P., Schauer, J. J., Stevens, P. S., Volkamer, R., and Zavala, M.: An overview of the MILAGRO 2006 Campaign: Mexico City emissions and their transport and transformation, Atmos. Chem. Phys., 10, 8697-8760, doi:10.5194/acp-10-8697-2010, 2010.

Moteki N. and Kondo, Y.: Method to measure time-dependent scattering cross-sections of particles evaporating in a laser beam, J. Aerosol Sci., 39, 348-364, doi:10.1029/2006JD007076, 2008.

Mukai, H. and Ambe, Y.: Characterization of a humic acid-like brown substance in airborne particulate matter and tentative identification of its origin, Atmos. Environ., 20, 813-819, 1986. 
Murphy, D. M.: The design of single particle laser mass spectrometers, Mass Spectrom. Rev., 26, 150-165, 2005.

Murphy, D. M., Thomson, D. S., and Mahoney, T. M. J.: In situ measurements of organics, meteoritic material, mercury, and other elements in aerosols at 5 to 19 kilometers, Science, 282, 16641669, 1998.

Murphy, D. M., Cziczo, D. J., Hudson, P. K., Schein, M. E., and Thomson, D. S.: Particle density inferred from simultaneous optical and aerodynamic diameters sorted by composition, J. Aerosol Sci., 35, 135-139, 2004.

Nizkorodov, S. A., Laskin, J., and Laskin, A.: Molecular chemistry of organic aerosols through applications of the high resolution mass spectrometry, Phys. Chem. Chem. Phys., 13, 3612-3629, doi:10.1039/C0CP02032J, 2011.

Noziere, B. and Esteve, W.: Organic reactions increasing the absorption index of atmospheric sulfuric acid aerosols, J. Geophys. Res., 32, L03812, doi:10.1029/2004GL021942, 2005.

Noziere, B., Dziedzic, P., and Cordova, A.: Formation of secondary light-absorbing "fulvic-like" oligomers: A common process in aqueous and ionic atmosphric particles?, Geophys. Res. Lett., 34, L21812, doi:10.1029/2007GL031300, 2007.

Noziere, B., Dziedzic, P., and Cordova, A.: Products and kinetics of the liquid-phase reaction of glyoxal catalyzed by ammonium ions $\left(\mathrm{NH}_{4}+\right)$, J. Phys. Chem. A, 113, 231-237, 2009.

Müller, D., Ansmann, A., Mattis, I., Tesche, M., Wandinger, U., Althausen, D., and Pisani, G.: Aerosol-type-dependent lidar ratios observed with Raman lidar, J. Geophys. Res., 112, D16202, doi:10.1029/2006JD008292, 2007.

Ogren, J.: Comment on "Calibration and intercomparison of filter-based measurements of visible light absorption by aerosols", Aerosol Sci. Technol., 44, 589-591, doi:10.1080/02786826.2010.482111, 2010.

Olfert, J., Kulkarni, P. S., and Wang, J.: Measurements of particle size distributions using a Fast Integrated Mobility Spectrometer, J. Aerosol Sci., 39, 940-956, doi:10.1016/j.jaerosci.2008.06.005, 2008.

Ottaviani, M., Cairns, B., Chowdhary, J., Van Diedenhoven, B., Knobelspiesse, K., Hostetler, C., Ferrare, R., Burton, S., Hair, J., Obland, M. D., and Rogers, R.: Polarimetric retrievals of surface properties in the region affected by the Deepwater Horizon oil spill, Remote Sens. Environ., 121, 389-403, 2011.

Pearson, G., Davies, F., and Collier, C.: An Analysis of the Performance of the UFAM Pulsed Doppler Lidar for Observing the Boundary Layer, J. Atmos. Ocean. Tech., 26, 240-250, 2009.

Pratt, K. A., Mayer, J. E., Holecek, J.C., Moffet, R. C., Sanchez, R. O., Rebotier, T. P., Furutani, H., Gonin, M., Fuhrer, K., Su, Y., Guazzotti, S., and Prather, K. A.: Development and Characterization of an Aircraft Aerosol Time-of-Flight_Mass Spectrometer, Anal. Chem., 81, 1792-1800, 2009.

Pratt, K. A., Twohy, C. H., Murphy, S. M., Moffet, R. C., Heymsfield, A. J., Gaston, C. J., DeMott, P. J., Field, P. R., Henn, T. R., Rogers, D. C., Gilles, M. K., Seinfeld, J. H., and Prather, K. A.: Observation of playa salts as nuclei in orographic wave clouds, J. Geophys. Res., 115, D15301, 2010.

Radney, J. G., Bazargan, M. H., Wright, M. E., and Atkinson, D. B.: Laboratory validation of aerosol extinction coefficient measurements by a field-deployable pulsed cavity ring-down transmissometer, Aerosol Sci. Technol., 43, 71-80, doi:10.1080/02786820802482536, 2009.
Ramanathan, V., Crutzen, P. J., Lelieveld, J., Mitra, A. P., Althausen, D., Anderson, J., Andreae, M. O., Cantrell, W., Cass, G. R., Chung, C. E., Clarke, A. D., Coakley, J. A., Collins, W. D., Conant, W. C., Dulac, F., Heintzenberg, J., Heymsfield, A. J., Holben, B., Howell, S., Hudson, J., Jayaraman, A., Kiehl, J. T., Krishnamurti, T. N., Lubin, D., McFarquhar, G., Novakov, T., Ogren, J. A., Podgorny, I. A., Prather, K., Priestley, K., Prospero, J. M., Quinn, P. K., Rajeev, K., Rasch, P., Rupert, S., Sadourny, R., Satheesh, S. K., Shaw, G. E., Sheridan, P., and Valero, F. P. J.: Indian Ocean experiment: An integrated analysis of the climate forcing and effects of the great Indo-Asian haze, J. Geophys. Res., 106, 28371-28398, doi:10.1029/2001JD900133, 2001.

Riemer, N., West, M., Zaveri, R. A., and Easter, R. C.: Simulating the evolution of soot mixing state with a particleresolved aerosol model, J. Geophys. Res., 114, D09202, doi:10.1029/2008JD011073, 2009.

Roach, P. J., Laskin, A., and Laskin, J.: Molecular characterization of organic aerosols using nanospray desorption electrospray ionization mass spectrometry, Anal. Chem., 82, 7979-7986, 2010.

Robinson, A. L., Donahue, N. M., Shrivastava, M. K., Weitkamp, E. A., Sage, A. M., Grieshop, A. P., Lane, T. E., Pierce, J. R., and Pandis, S. N.: Rethinking organic aerosols: Semivolatile emissions and photochemical aging, Science, 315, 1259-1262, 2007.

Rogers, R. R., Hair, J. W., Hostetler, C. A., Ferrare, R. A., Obland, M. D., Cook, A. L., Harper, D. B., Burton, S. P., Shinozuka, Y., McNaughton, C. S., Clarke, A. D., Redemann, J., Russell, P. B., Livingston, J. M., and Kleinman, L. I.: NASA LaRC airborne high spectral resolution lidar aerosol measurements during MILAGRO: observations and validation, Atmos. Chem. Phys., 9, 4811-4826, doi:10.5194/acp-9-4811-2009, 2009.

Saathoff, H., Naumann, K. -H., Schnaiter, M., Schöck, W., Möhler, O., Schurath, U., Weingartner, E., Gysel, M., and Baltensperger, U.: Coating of soot and $\left(\mathrm{NH}_{4}\right)_{2} \mathrm{SO}_{4}$ particles by ozonolysis products of $\alpha$-pinene, J. Aerosol Sci., 34, 1297-1321, 2003.

Sareen, N., Schwier, A. N., Shapiro, E. L., Mitroo, D., and McNeill, V. F.: Secondary organic material formed by methylglyoxal in aqueous aerosol mimics, Atmos. Chem. Phys., 10, 997-1016, doi:10.5194/acp-10-997-2010, 2010.

Seinfeld, J. H. and Pandis, S. N.: Atmospheric Chemistry and Physics: From Air Pollution to Climate Change, John Wiley, Hoboken, NJ, 1998.

Schnaiter, M., Linke, C., Möhler, O., Naumann, K.-H., Saathoff, H., Wagner, R., Schurath, U., and Wehner, B.: Absorption amplification of black carbon internally mixed with secondary organic aerosol, J. Geophys. Res., 110, D19204, doi:10.1029/2005JD006046, 2005.

Schwarz, J. P., Gao, R. S., Fahey, D. W., Thomson, D. S., Watts, L. A., Wilson, J. C., Reeves, J. M., Darbeheshti, M., Baumgardner, D. G., Kok, G. L., Chung, S. H., Schulz, M., Hendricks, J., Lauer, A., Kärcher, B., Slowik, J. G., Rosenlof, K. H., Thompson, T. L., Langford, A. O., Loewenstein, M., and Aikin, K. C.: Single-particle measurements of midlatitude black carbon and light-scattering aerosols from the boundary layer to the lower stratosphere, J. Geophys. Res., 111, D16207, doi:10.1029/2006JD007076, 2006.

Schwarz, J. P., Gao, R. S., Fahey, D. W., Thomson, D. S., Watts, L. A., Wilson, J. C., Reeves, J. M., Darbeheshti, M., Baumgardner, D. G., Kok, G. L., Chung, S. H., Schulz, M., Hendricks, J., Lauer, A., Kärcher, B., Slowik, J. G., Rosenlof, K. H., Thomp- 
son, T. L., Langford, A. O., Loewenstein, M., and Aikin, K. C.: Coatings and their enhancement of black carbon light absorption in the tropical atmosphere, J. Geophys. Res., 113, D03203, doi:10.1029/2007JD009042, 2008a.

Schwarz, J. P., Gao, R. S., Spackman, J. R., Watts, L. A., Thomson, D. S., Fahey, D. W., Ryerson, T. B., Peischl, J., Holloway, J. S., Trainer, M., Frost, G. J., Baynard, T., Lack, D. A., de Gouw, J. A., Warneke, C., Del Negro, L. A.: Measurement of the mixing state, mass, and optical size of individual black carbon particles in urban and biomass burning emissions, Geophys. Res. Lett., 35, L13810, doi:10.1029/2008GL033968, 2008b.

Shapiro, E. L., Szprengiel, J., Sareen, N., Jen, C. N., Giordano, M. R., and McNeill, V. F.: Light-absorbing secondary organic material formed by glyoxal in aqueous aerosol mimics, Atmos. Chem. Phys., 9, 2289-2300, doi:10.5194/acp-9-2289-2009, 2009.

Sem, G. J.: Design and performance characteristics of three continuous-flow condensation particle counters: a summary, Atmos. Res., 62, 267-294, doi:10.1016/S0169-8095(02)00014-5, 2002.

Sinreich, R., Coburn, S., Dix, B., and Volkamer, R.: Ship-based detection of glyoxal over the remote tropical Pacific Ocean, Atmos. Chem. Phys., 10, 11359-11371, doi:10.5194/acp-1011359-2010, 2010.

Slowik, J. G., Stroud, C., Bottenheim, J. W., Brickell, P. C., Chang, R. Y.-W., Liggio, J., Makar, P. A., Martin, R. V., Moran, M. D., Shantz, N. C., Sjostedt, S. J., van Donkelaar, A., Vlasenko, A., Wiebe, H. A., Xia, A. G., Zhang, J., Leaitch, W. R., and Abbatt, J. P. D.: Characterization of a large biogenic secondary organic aerosol event from eastern Canadian forests, Atmos. Chem. Phys., 10, 2825-2845, doi:10.5194/acp-10-2825-2010, 2010.

Smith, J. D. and Atkinson, D. B.: A portable pulsed cavity ringdown transmissometer for measurement of the optical extinction of the atmospheric aerosol, Analyst, 126, 1216-1220, 2001.

Song, C., Zaveri, R. A., Alexander, M. L., Thornton, J. A., Madronich, S., Ortega, J. V., Zelenyuk, A., Yu, X.-Y., Laskin, A., and Maughan, D.: Effect of hydrophobic primary organic aerosol on secondary organic aerosol formation from ozonolysis of $\alpha$-pinene, Geophys. Res. Lett., 34, L20803, doi:10.1029/2007GL030720, 2007.

Sorooshian, A., Brechtel, F. J., Ma, Y., Weber, R. J., Corless, A., Flagan, R. C., and Seinfeld, J. H.: Modeling and Characterization of a Particle-into-Liquid Sampler (PILS), Aerosol Sci. Technol., 40, 396-409, doi:10.1080/02786820600632282, 2006.

Spencer, M. T., Shields, L. G., and Prather, K. A.: Simultaneous measurement of the effective density and chemical composition of ambient aerosol particles, Environ. Sci. Technol., 41, 13031309, 2007.

Springston, S. R., Kleinman, L. I., Nunnermacker, L. J., Brechtel, F., Lee, Y.-N., and Wang, J.: Chemical evolution of an isolated power plant plume during the TexAQs 2000 study, Atmos. Environ., 39, 3431-3443, 2005.

Stephens, M., Turner, N., and Sandberg, J.: Particle identification by laser-induced incandescence in a solid-state laser cavity, Appl. Optics, 42, 3726-3736, 2003.

Steiner, A. L., Cohen, R. C., Harley, R. A., Tonse, S., Millet, D. B., Schade, G. W., and Goldstein, A. H.: VOC reactivity in central California: comparing an air quality model to ground-based measurements, Atmos. Chem. Phys., 8, 351-368, doi:10.5194/acp-8351-2008, 2008.
Stull, R. B.: An Introduction to Boundary Layer Meteorology, Kluwer, Boston, 1988.

Subramanian, R., Kok, G. L., Baumgardner, D., Clarke, A., Shinozuka, Y., Campos, T. L., Heizer, C. G., Stephens, B. B., de Foy, B., Voss, P. B., and Zaveri, R. A.: Black carbon over Mexico: the effect of atmospheric transport on mixing state, mass absorption cross-section, and BC/CO ratios, Atmos. Chem. Phys., 10, 219 237, doi:10.5194/acp-10-219-2010, 2010.

Sugimoto, N. and Lee, C. H.: Characteristics of dust aerosols inferred from lidar depolarization measurements at two wavelengths, Appl. Optics, 45, 7468-7474, 2006.

Surratt, J. D., Goómez-Gonzaález, Y., Chan, A. W. H., Vermeylen, R., Shahgholi, M., Kleindienst, T. E., Edney, E. O., Offenberg, J. H., Lewandowski, M., Jaoui, M., Maenhaut, W., Claeys, M., Flagan, R. C., and Seinfeld, J. H.: Organosulfate formation in biogenic secondary organic aerosol, J. Phys. Chem. A, 112, 83458378, doi:10.1021/jp802310p, 2008.

Surratt, J. D., Chan, A. W. H., Eddingsaas, N. C., Chan, M., Loza, C. L., Kwan, A. J., Hersey, S. P., Flagan, R. C., Wennberg, P. O., and Seinfeld, J. H.: Reactive intermediates revealed in secondary organic aerosol formation from isoprene, P. Natl. Acad. Sci. USA, 107, 6640-6645, 2010.

Tritscher, T., Jurányi, Z., Martin, M., Chirico, R., Gysel, M., Heringa, M. F., DeCarlo, P. F., Sierau, B., Prévôt, A. S. H., Weingartner, E., and Baltensperger, U.: Changes of hygroscopicity and morphology during ageing of diesel soot, Environ. Res. Lett., 6, 034026, doi:10.1088/1748-9326/6/3/034026, 2011.

Warneke, C., Froyd, K. D., Brioude, J., Bahreini, R., Brock, C. A., Cozic, J., de Gouw, J. A., Fahey, D. W., Ferrare, R., Holloway, J. S., Middlebrook, A. M., Miller, L., Montzka, S., Schwarz, J. P., Sodemann, H., Spackman, J. R., and Stohl, A.: An important contribution to springtime Arctic aerosol from biomass burning in Russia, Geophys. Res. Lett., 37, L01801, doi:10.1029/2009g1041816, 2010.

Ulbrich, I. M., Canagaratna, M. R., Zhang, Q., Worsnop, D. R., and Jimenez, J. L.: Interpretation of organic components from Positive Matrix Factorization of aerosol mass spectrometric data, Atmos. Chem. Phys., 9, 2891-2918, doi:10.5194/acp-9-2891-2009, 2009.

Vaden, T. D., Imre, D., Beranek, J., Shrivastava, M., and Zelenyuk, A.: Evaporation kinetics and phase of laboratory and ambient secondary organic aerosol, P. Natl. Acad. Sci. USA, 108, 2190 2195, 2011a.

Vaden, T. D., Imre, D., Beranek, J., and Zelenyuk, A.: Extending the capabilities of single particle mass spectrometry: I. Measurements of aerosol number concentration, size distribution, and asphericity, Aerosol Sci. Technol., 45, 113-124, 2011 b.

Vaden, T. D., Imre, D., Beranek, J., and Zelenyuk, A.: Extending the capabilities of single particle mass spectrometry: II. Measurements of aerosol particle density without DMA, Aerosol Sci. Technol., 45, 125-135, 2011c.

Virtanen, A., Joutsensaari, J., Koop, T., Kannosto, J., Yli-Pirila, P., Leskinen, J., Makela, J. M., Holopainen, J. K., Poschl, U., Kulmala, M., Worsnop, D. R., and Laaksonen, A.: An amorphous solid state of biogenic secondary organic aerosol particles, Nature, 467, 824-827, 2010.

Volkamer, R., Jimenez, J. L., San Martini, F., Dzepina, K., Zhang, Q., Salcedo, D., Molina, L. T., Worsnop, D. R., and Molina, M. J.: Secondary organic aerosol formation from anthropogenic air 
pollution: Rapid and higher than expected, Geophys. Res. Lett., 33, L17811, doi:10.1029/2006GL026899, 2006.

Volkamer, R., Coburn, S., Dix, B., and Sinreich, R.: MAX-DOAS observations from ground, ship, and research aircraft: maximizing signal-to-noise to measure "weak" absorbers, in: SPIE Proceedings Ultraviolet and Visible Ground- and Space-based Measurements, Trace Gases, Aerosols and Effects, San Diego, 2-9 August 2009, 746203, doi:10.1117/12.826792, 2009.

Waquet, F., Cairns, B., Knobelspiesse, K., Chowdhary, J., Travis, L. D., Schmid, B., and Mishchenko, M. I.: Polarimetric remote sensing of aerosols over land, J. Geophys. Res., 114, D01206, doi:10.1029/2008JD010619, 2009.

Warneke, C., Froyd, K. D., Brioude, J., Bahreini, R., Brock, C. A., Cozic, J., de Gouw, J. A., Fahey, D. W., Ferrare, R., Holloway, J. S., Middlebrook, A. M., Miller, L., Montzka, S., Schwarz, J. P., Sodemann, H., Spackman, J. R., and Stohl, A.: An important contribution to springtime Arctic aerosol from biomass burning in Russia, Geophys. Res. Lett., 37, L01801, doi:10.1029/2009GL041816, 2010.

Weber, R. J., Sullivan, A. P., Peltier, R. E., Russell, A., Yan, B., Zheng, M., Gouw, J. A. d., Warneke, C., Brock, C., Holloway, J. S., Atlas, E. L., and Edgerton, E.: A study of secondary organic aerosol formation in the anthropogenic influenced southeastern United States, J. Geophys. Res., 112, D13302, doi:10.1029/2007JD008408, 2007.

Wentzel, M., Gorzawski, H., Naumann, K. H., Saathoff, H., and Weinbruch, S.: Transmission electron microscopical and aerosol dynamical characterization of soot aerosols, J. Aerosol Sci., 34, 1347-1370, 2003.

Wexler, A. S. and Seinfeld, J. H.: Second-generation inorganic aerosol model, Atmos. Environ., 25A, 2731-2748, 1991.

Zaveri, R. A., Easter, R. C., Fast, J. D., and Peters, L. K.: Model for Simulating Aerosol Interactions and Chemistry (MOSAIC), J. Geophys. Res., 113, D13204, doi:10.1029/2007JD008782, 2008.

Zaveri, R. A., Berkowitz, C. M., Brechtel, F. J., Gilles, M. K., Hubbe, J. M., Jayne, J. T., Kleinman, L. I., Laskin, A., Madronich, S., Onasch, T. B., Pekour, M., Springston, S. R., Thornton, J. A., Tivanski, A. V., and Worsnop, D. R.: Nighttime chemical evolution of aerosol and trace gases in a power plant plume: Implications for secondary organic nitrate and organosulfate aerosol formation, $\mathrm{NO}_{3}$ radical chemistry, and $\mathrm{N}_{2} \mathrm{O}_{5}$ heterogeneous hydrolysis, J. Geophys. Res., 115, D12304, doi:10.1029/2009JD013250, 2010a.

Zaveri, R. A., Barnard, J. C., Easter, R. C., Riemer, N., West, M.: Particle-resolved simulation of aerosol size, composition, mixing state, and the associated optical and cloud condensation nuclei activation properties in an evolving urban plume, J. Geophys. Res., 115, D17210, doi:10.1029/2009JD013616, 2010b.
Zelenyuk, A. and Imre, D.: Single particle laser ablation time-offlight mass spectrometer: An introduction to SPLAT, Aerosol Sci. Technol., 39, 554-568, 2005.

Zelenyuk, A. and Imre, D.: Beyond single particle mass spectrometry: multidimensional characterisation of individual aerosol particles, Int. Rev. Phys. Chem., 28, 309-358, 2009.

Zelenyuk, A., Imre, D., Han, J. H., and Oatis, S.: Simultaneous measurements of individual ambient particle size, composition, effective density, and hygroscopicity, Anal. Chem., 80, 1401-1407, 2008.

Zelenyuk, A., Yang, J., Choi, E., and Imre, D.: SPLAT II: An aircraft compatible, ultra-sensitive, high precision instrument for in-situ characterization of the size and composition of fine and ultrafine particles, Aerosol Sci. Technol., 43, 411-424, 2009.

Zelenyuk, A., Imre, D., Earle, M., Easter, R., Korolev, A., Leaitch, R., Liu, P., Macdonald, A. M., Ovchinnikov, M., and Strapp, W.: In situ characterization of cloud condensation nuclei, interstitial, and background particles using the single particle mass spectrometer, SPLAT II, Anal. Chem., 82, 7943-7951, 2010.

Zhang, Q., Alfarra, M. R., Worsnop, D. R., Allan, J. D., Coe, H., Canagaratna, M. R., and Jimenez, J. L.: Deconvolution and quantification of hydrocarbon-like and oxygenated organic aerosols based on aerosol mass spectrometry, Environ. Sci. Technol., 39, 4938-4952, doi:4910.1021/es0485681, 2005.

Zhang, Q., Jimenez, J. L., Canagaratna, M. R., Allan, J. D., Coe, H., Ulbrich, I., Alfarra, M. R., Takami, A., Middlebrook, A. M., Sun, Y. L., Dzepina, K., Dunlea, E., Docherty, K., DeCarlo, P. F., Salcedo, D., Onasch, T., Jayne, J. T., Miyoshi, T., Shimono, A., Hatakeyama, S., Takegawa, N., Kondo, Y., Schneider, J., Drewnick, F., Borrmann, S., Weimer, S., Demerjian, K., Williams, P., Bower, K., Bahreini, R., Cottrell, L., Griffin, R. J., Rautiainen, J., Sun, J. Y., Zhang, Y. M., and Worsnop, D. R.: Ubiquity and dominance of oxygenated species in organic aerosols in anthropogenically-influenced Northern Hemisphere mid-latitudes, Geophys. Res. Lett., 34, L13801, doi:10.1029/2007GL029979, 2007.

Zhang, Q., Jimenez, J. L., Canagaratna, M., Ng, N. L., Ulbrich, I., Worsnop, D., and Sun, Y. L.: Understanding organic aerosols via factor analysis of aerosol mass spectrometry: a review, Anal. Bioanal. Chem., 401, 3045-3067, doi:10.1007/s00216-0001105355-y, 2011.

Zhang, R., Khalizov, A. F., Pagels, J., Zhang, D., Xue, H., and McMurry, P. H.: Variability in morphology, hygroscopicity, and optical properties of soot aerosols during atmospheric processing, P. Natl. Acad. Sci. USA, 105, 10291-10296, 2008. 